\title{
Photogrammetric anthropometry in children
}

Citation for published version (APA):

Penders, B. (2018). Photogrammetric anthropometry in children. [Doctoral Thesis, Maastricht University]. Datawyse / Universitaire Pers Maastricht. https://doi.org/10.26481/dis.20181116bp

Document status and date:

Published: 01/01/2018

DOI:

10.26481/dis.20181116bp

Document Version:

Publisher's PDF, also known as Version of record

\section{Please check the document version of this publication:}

- A submitted manuscript is the version of the article upon submission and before peer-review. There can be important differences between the submitted version and the official published version of record.

People interested in the research are advised to contact the author for the final version of the publication, or visit the DOI to the publisher's website.

- The final author version and the galley proof are versions of the publication after peer review.

- The final published version features the final layout of the paper including the volume, issue and page numbers.

Link to publication

\footnotetext{
General rights rights.

- You may freely distribute the URL identifying the publication in the public portal. please follow below link for the End User Agreement:

www.umlib.nl/taverne-license

Take down policy

If you believe that this document breaches copyright please contact us at:

repository@maastrichtuniversity.nl

providing details and we will investigate your claim.
}

Copyright and moral rights for the publications made accessible in the public portal are retained by the authors and/or other copyright owners and it is a condition of accessing publications that users recognise and abide by the legal requirements associated with these

- Users may download and print one copy of any publication from the public portal for the purpose of private study or research.

- You may not further distribute the material or use it for any profit-making activity or commercial gain

If the publication is distributed under the terms of Article $25 \mathrm{fa}$ of the Dutch Copyright Act, indicated by the "Taverne" license above, 


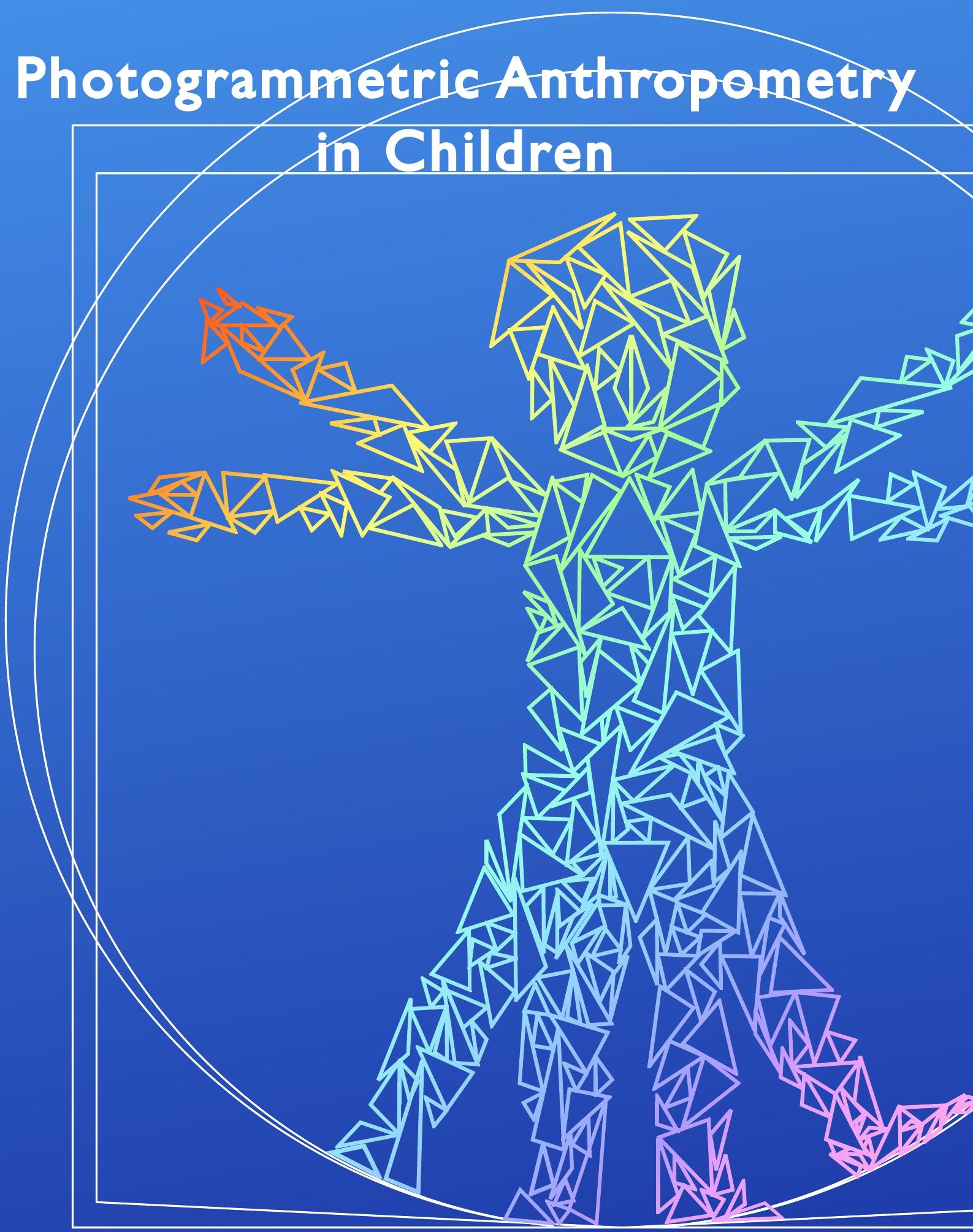

\section{Bas Penders}


(C) Copyright Bas Penders, Maastricht 2018

ISBN: 978-94-93019-05-8

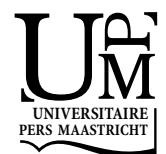

Cover design: Jelle Penders

Layout: Bas Penders, Ubbo Noordhof, Datawyse

Printed by: Datawyse / Universitaire Pers Maastricht

De totstandkoming van dit proefschrift werd mede mogelijk gemaakt door een financiële bijdrage van Ferring Pharmaceuticals. 


\title{
Photogrammetric anthropometry in Children
}

\author{
PROEFSCHRIFT
}

Ter verkrijging van de graad van doctor aan de Universiteit Maastricht, op gezag van de Rector Magnificus, Prof. dr. Rianne M. Letschert volgens het besluit van het College van Decanen, in het openbaar te verdedigen op

vrijdag 16 november 2018 om 12:00 uur.

door

\section{Bas Penders}

Geboren op 13 december 1992 te Maastricht 


\section{Promotor}

Prof. dr. L.J.I. Zimmermann

\section{Copromotoren}

Dr. W.J.M. Gerver

Dr. A.C.E. Vreugdenhil

\section{Beoordelingscommissie}

Prof. dr. B.W.W. Kramer (voorzitter)

Prof. dr. C.E. Blanco (Royal College of Surgeons, Dublin, Ireland)

Prof. dr. L.W. van Rhijn

Prof. dr. C.E.M. de Die - Smulders

Dr. H.L. Claahsen - van der Grinten (Radboud UMC, Nijmegen) 
Contents

Chapter 1 | General introduction

Chapter 2| Body Proportions

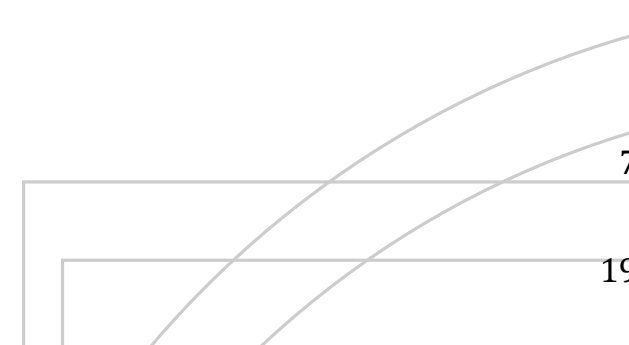

Chapter 3 | Validating Paediatric Morphometrics: body proportion measurement using photogrammetric anthropometry

Chapter 4| Estimation of body fat percentage in children and adolescents using photogrammetric anthropometry

Chapter 5 | Body Proportions in Children with Kabuki Syndrome

Chapter 6 | An analysis of body proportions in children with CHARGE syndrome using photogrammetric anthropometry

Chapter 7 | General discussion

Summary

Samenvatting

Valorisation

Dankwoord

Curriculum vitae

List of Publications 



\section{Chapter 1}

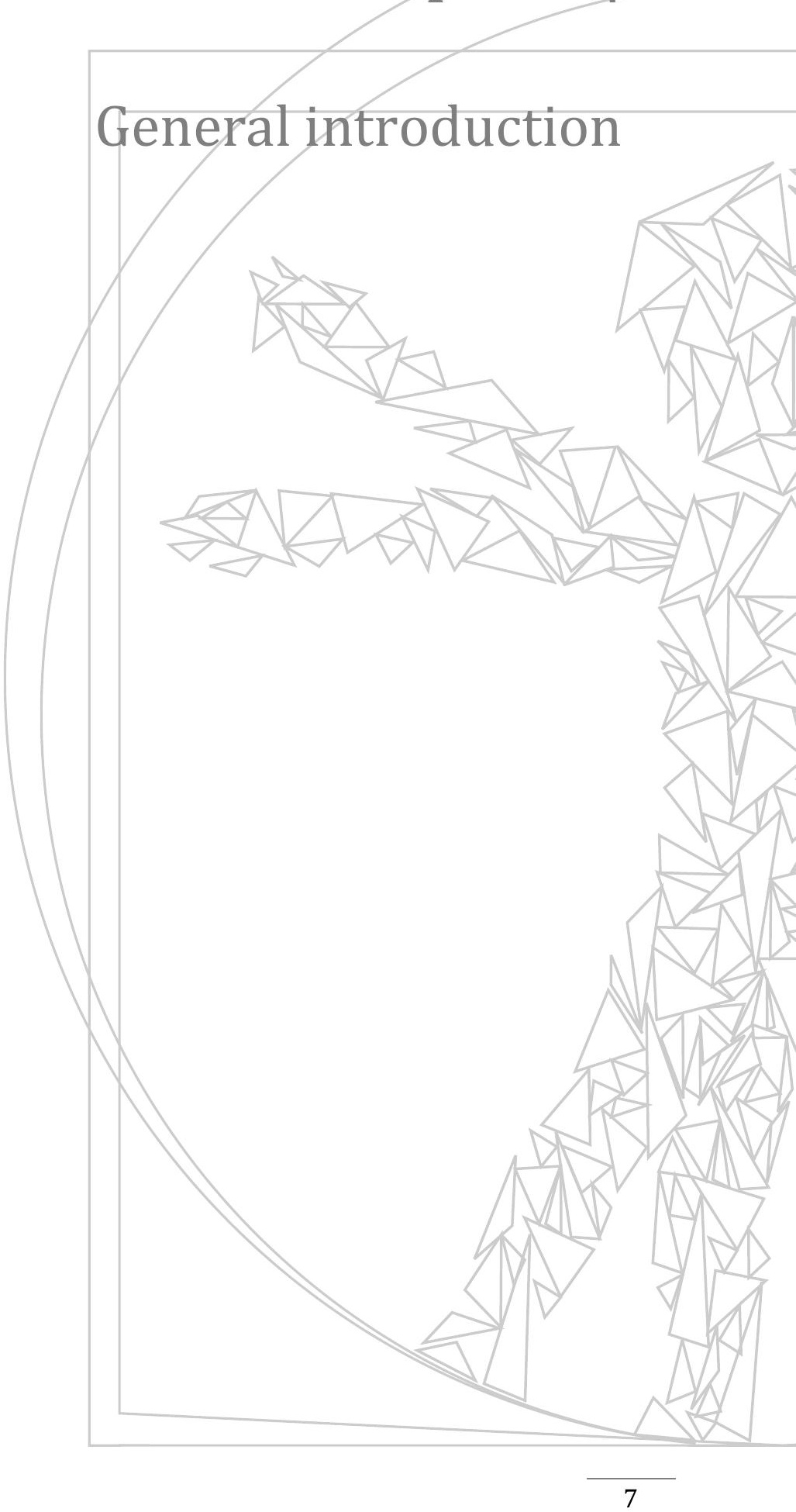





\section{Anthropometry: origin and application}

The measurement of the human individual, known as anthropometry (from the

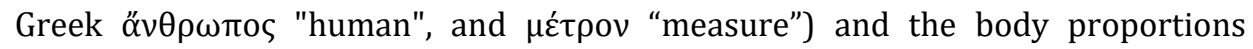
derived from these measurements have attracted interest for centuries. One of the most iconic displays of proportions is the "Vitruvian man" by Leonardo da Vinci (c. 1490), based on the works of the architect Marcus Vitruvius (c. 80-70 BC - c.20 BC). This drawing depicts the symmetry and proportion in the human body, as found in nature, which was thought to lead to the universal measures of true beauty.

In more recent times, anthropometry has been implemented in a broad range of fields of study, such as criminology, behavioural sciences, growth and development in paediatrics, and syndrome recognition in genetics. Alphonse Bertillon (1853 1914) for example, used body measurements as a tool for identification of individuals such as in criminals, called the Bertillonage method ${ }^{1}$. This resulted in an extensive set of measurements and materials, many of which are still used in some form to this date (figure 1).

THE ANTHROPOMETRICAL SIGNALMENT

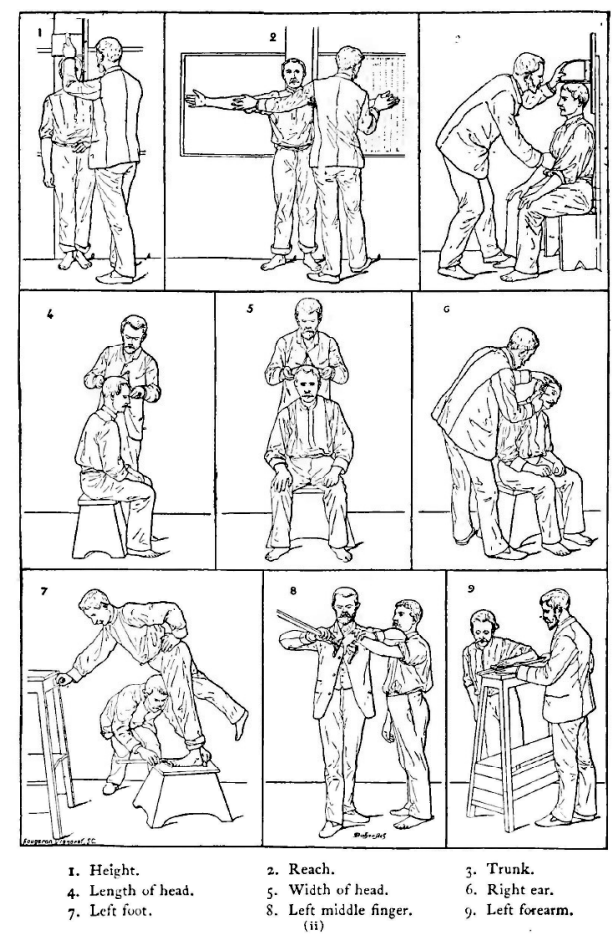

Figure 1 | Bertillonage measurement method.

From Bertillon, A. Signaletic instructions including the theory and practice of anthropometrical identification. (1896) 
Cesare Lombroso (1835-1909) went even further in claiming to link certain body proportions to a criminal predisposition, the physiognomy, believing in the concept of a born criminal ${ }^{2}$. Later, William Sheldon (1898-1977) implemented anthropometry for his somatotyping theory in constitutional psychology, in which he postulated that certain body proportions are directly related to behavioural characteristics $^{3}$. He categorised people into three somatotypes: the endomorphs, mesomorphs and ectomorphs. The endomorphic body type would be characterised by a round and soft body shape and linked to a 'viscerotonic' personality (i.e. relaxed and sociable). People with the mesomorphic body type would have a hard, muscular body and a 'somotonic' personality (i.e. active and assertive). Lastly, thin and fineboned people were found to have the ectomorphic body type, which would be related to a 'cerebrotonic' personality (i.e. introverted and thoughtful).

All these examples have later been discounted as subjective and largely discredited, however they showcase anthropometry, the diversity of its uses and importance adhered to body proportions.

\section{The application of body proportions in the study of growth}

Count Philibert de Montbeillard (1720-1785) plotted his son's height from birth to the age of 18 , to illustrate the pattern of growth and thus creating the first growth curve ${ }^{4,5}$.

Of the numerous anthropometric growth studies performed since then to investigate the transformation of body proportions during growth, best known is the study by Medawar in 1943. He found that the shape of a human being, from the 5 th month of foetal life to maturity, can be represented as a single process of continuous transformation in time. His mathematical analysis provided the headtrunk-legs gradient, which describes how the head matures faster than the trunk, and the trunk faster than the legs (figure 2).

The alteration of body proportions which thus occurs, is the result of selective regional growth. This pattern of development can be quantified by the interrelationship between various linear measurements of the body. Traditionally, this changing of body proportions is reflected in various ratios, including head circumference to crown-rump length, height to sitting height and arm span to height. The transformation process of body proportions is unidirectional, which means that any given body proportion will only exist at one time and not reoccur in the maturation process. Therefore, anthropometric measurements allow us to associate the shape of a human body with a particular chronological age. However, to make the use of body proportions suitable for clinical practise, one needs to have reference values of the specific population to be able to mark deviation from the norm. 


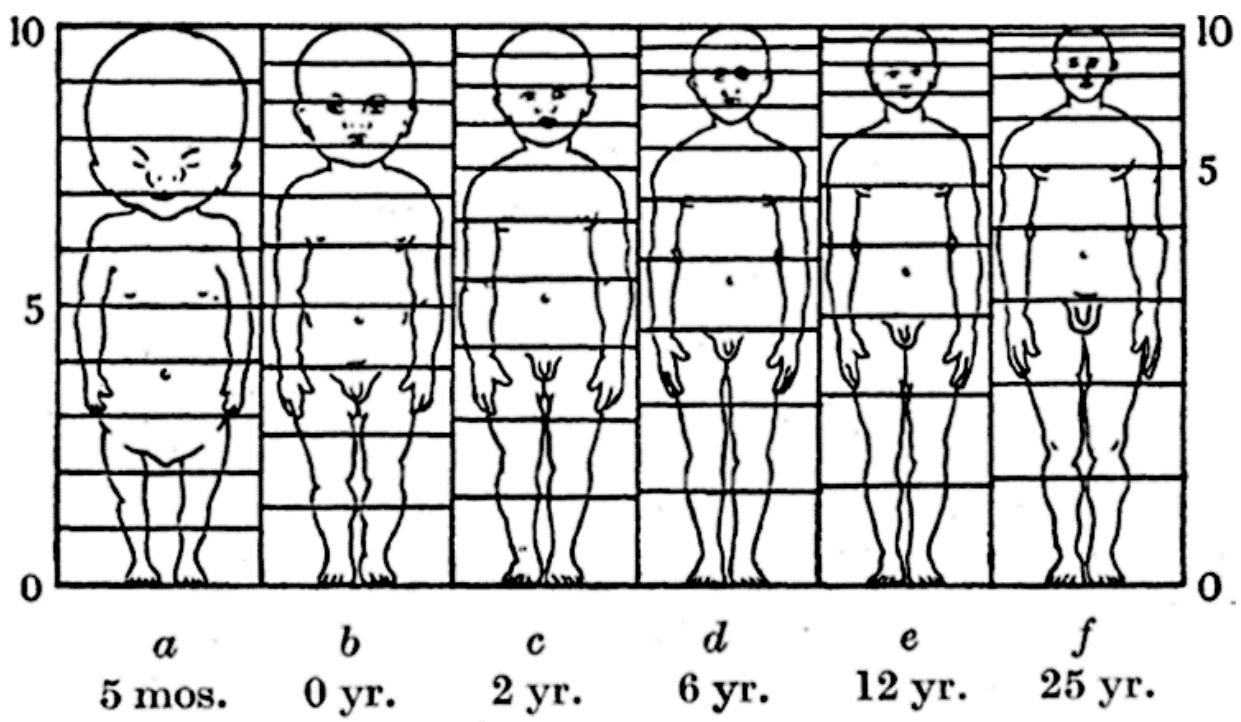

Figure 2 | Head-trunk-legs gradient.

From Medawar, P. B. The shape of the human being as a function of time. Proceedings of the Royal Society of London. Series B - Biological Sciences 132, 133-141. (1944)

Only a few studies have reported reference values for body proportions, these include the British growth studies (1946-1954) by J.M.Tanner ${ }^{7}$, the Swiss growth studies (1954-1976) by A.Prader ${ }^{8}$ and the Norwegian growth studies (1971-1974 and 2003-2006) by P.E.Waaler9,10. In view of the lack of such data for the healthy Dutch population, a series of growth studies were performed between 1980 and 2000 to characterise normal body proportions for all ages by W.J.M. Gerver ${ }^{11,12}$. The results of these studies are presented in the reference manual, Paediatric Morphometrics, and are still the most up to date reference values for the Dutch population ${ }^{13}$. Therefore, these are used as reference in this thesis.

\section{Relevance of body proportions}

Human growth is the summation of the development of different parts of the body, following a predictable timetable of maturation. This process is influenced and guided by genetic, hormonal, and environmental factors. Therefore, when abnormal body proportions occur, due to an imbalance of growth of either the whole body or certain body parts, this hallmarks a disturbance in the natural process of maturation.

Many such disturbances have been associated with, and provide recognisable patterns of disproportionate growth of particular diseases, such as in Marfan syndrome, Turner syndrome, and chondrodysplasia ${ }^{14-17}$. However, for many syndromes and diseases it has not yet been investigated if characteristic dysmorphic 
features are present, since collecting accurate and extensive data on body proportions is an arduous task and requires specialised instruments and training.

Investigation of body proportions is important to assess if growth disturbance is involved and if it is present in only a specific body part or of a more general nature. This distinction can be important because, when the disturbance in growth can be related to the disease process, this may give insight into the pathogenesis of the disease ${ }^{18}$.

Therefore, knowledge of body proportions is essential in judging patients' development, in making diagnoses and in evaluating therapeutic interventions.

\section{Current measurement methods of body proportions}

To date, a number of instruments are available for accurate anthropometric measurement. The use of certain instruments depends on the extensiveness of measurements routinely taken and the degree of expertise of the measurer. These instruments include at minimum: a stadiometer and supine measuring table for the measurement of height and supine length respectively, and an infant scale and regular scale for the measurement of body weight. Additionally, the supine measuring table and sitting height table are used to measure crown-rump length and sitting height ${ }^{18}$.

When additional measurements are to be taken, callipers are best used. In this regard, the Harpenden anthropometer is an excellent instrument for taking various manual measurements, including: biacromial distance, biiliacal distance and measurement of the limbs and their subparts ${ }^{13}$.

These manual measurement instruments are the standard instruments used in this thesis.

\section{Current measurement methods of body composition}

Various techniques are available to measure body composition in children. The most often used techniques are: deuterium dilution, hydrostatic weighing, airdisplacement plethysmography and bioelectric impedance analysis (BIA). These techniques vary in accuracy, complexity and practical applicability. In this thesis, deuterium dilution and air-displacement plethysmography are used as reference measurements in the determination of body fat mass. Both techniques are twocomponent techniques, dividing the body into fat mass (FM) and fat free mass (FFM). These techniques provide an accurate prediction of fat mass in children across the whole weight spectrum, as opposed to BIA, and are patient-friendly and suitable for practically all children, as opposed to hydrostatic weighing ${ }^{19-23}$. 


\section{The development of photogrammetric anthropometry}

Taking a multitude of precise manual measurements of an individual is a trying task. Especially in the field of paediatrics when an unwilling child has to be measured. Therein lies the strength of photography, standardised photographs take only a couple of minutes to obtain and provides the measurer with the luxury to perform as many measurements as wanted, at a time that is most convenient for the measurer. Additionally, photography provides a permanent record of the subject's appearance, so that the original data remains available for future use, as opposed to manual measurements. The use of photography as a standalone method for accurate anthropometry has been initially proposed by William Sheldon in 194024. In 1949, James Tanner further explored the practical applicability of photographs as a substitute for manual anthropometric measurements, and provided initial statements on use of materials and subject positioning25,26. Later on, he predominantly used this photogrammetric anthropometry technique as a means of classifying physique and somatotyping ${ }^{27}$. Since then the use of photographs for anthropometric measurements has been scarce and mainly focused on facial description in the field of clinical genetics and scoliosis evaluation in orthopaedics ${ }^{28-}$ 31 .

The main purpose of the thesis is to reinvent photogrammetric anthropometry for the measurement of body proportions in children, explore its strengths and weaknesses and the diversity of its uses.

\section{Thesis outline}

The studies presented in this thesis were coordinated from the department of Paediatric Endocrinology of the Maastricht University Medical Centre (MUMC+). Collaborations were instigated with the Centre for Overweight Adolescent and Children's Healthcare (COACH), the MUMC+ department of Clinical Genetics and the department of Clinical Genetics of the University Medical Centre Groningen (UMCG).

\section{The main research questions of this thesis are:}

- $\quad$ Can photogrammetric anthropometry be implemented as an accurate, fast and easy to use alternative to manual anthropometry in the measurement of body proportions in children?

- How can photogrammetric anthropometry contribute to the assessment of growth, health status and syndrome recognition in paediatric practice?

In chapter 2 , an in-depth overview is given on the current manual measurement techniques for body proportions and a first look into the development of the new photogrammetric measurement method: Paediatric Morphometrics, by our research group. The development and validation of this method is presented in chapter 3. 


\section{Chapter 1}

The next chapters provide an exploration of the practical uses of the photogrammetric method.

In chapter 4 , the relationship between body proportions and body fat percentage is investigated across a broad weight spectrum and wide age range.

As previously stated, the occurrence of abnormal body proportions may indicate a disturbance in the process of growth and maturation, and analysis of these proportions may therefore provide a recognizable pattern for particular diseases and syndromes. Since it has not yet been investigated if dysmorphic features are a present characteristic of many syndromes, photogrammetric anthropometry was used to study the body proportions in Kabuki syndrome and CHARGE syndrome, two syndromes in which growth and developmental aberrations have been described. These results are presented in chapter 5 and 6 respectively. 


\section{References}

1. Bertillon, A. Signaletic instructions including the theory and practice of anthropometrical identification. The Werner company, Chicago, New York, London (1896).

2. Lombroso, C. \& Lombroso, G. Criminal Man. Putnam, New York (1911).

3. Herbert, S.W. Atlas of Men: A Guide for Somatotyping the Adult Male at All Ages. New York: Harper. (1954).

4. Cole, T.J. The development of growth references and growth charts. Ann Hum Biol 39, 382-394 (2012).

5. Tanner, J.M. Normal growth and techniques of growth assessment. Clinics in endocrinology and metabolism 15, 411-451 (1986).

6. Medawar, P.B. The shape of the human being as a function of time. Proceedings of the Royal Society of London. Series B - Biological Sciences 132, 133-141 (1944).

7. Tanner, J.M., Whitehouse, R.H. \& Takaishi, M. Standards from birth to maturity for height, weight, height velocity, and weight velocity: British children, 1965. I. Archives of disease in childhood 41, 454-471 (1966).

8. Prader, A., Largo, R.H., Molinari, L. \& Issler, C. Physical growth of Swiss children from birth to 20 years of age. First Zurich longitudinal study of growth and development. Helvetica paediatrica acta. Supplementum 52, 1-125 (1989).

9. Waaler, P.E. Anthropometric studies in Norwegian children. Acta Paediatr Scand Suppl 308, 1-41 (1983).

10. Juliusson, P.B., et al. [Growth references for Norwegian children]. Tidsskrift for den Norske laegeforening : tidsskrift for praktisk medicin, ny raekke 129, 281-286 (2009).

11. Gerver, W.J., Drayer, N.M. \& Schaafsma, W. Reference values of anthropometric measurements in Dutch children. The Oosterwolde Study. Acta paediatrica Scandinavica 78, 307-313 (1989).

12. Gerver, W.J., De Bruin, R. \& Drayer, N.M. A persisting secular trend for body measurements in Dutch children. The Oosterwolde II Study. Acta Paediatr 83, 812-814 (1994).

13. Gerver, W.J.M. \& de Bruin, R. Paediatric Morphometrics: A Reference Manual, (Universitaire Pers Maastricht, 2011).

14. Fredriks, A.M., et al. Nationwide age references for sitting height, leg length, and sitting height/height ratio, and their diagnostic value for disproportionate growth disorders. Archives of disease in childhood 90, 807-812 (2005).

15. Schott, G.D. The extent of man from Vitruvius to Marfan. Lancet (London, England) 340, 1518-1520 (1992).

16. Rongen-Westerlaken, C., et al. Body proportions in individuals with Turner syndrome. The Dutch Growth Hormone Working Group. European journal of pediatrics 152, 813-817 (1993).

17. Sas, T.C., et al. Body proportions during long-term growth hormone treatment in girls with Turner syndrome participating in a randomized dose-response trial. J Clin Endocrinol Metab 84, 4622-4628 (1999).

18. Gripp, K.W., Slavotinek, A.M., Hall, J.G. \& Allanson, J.E. Handbook of Physical Measurements, (Oxford University Press, United States of America, 2013).

19. Wells, J.C. \& Fuller, N.J. Precision of measurement and body size in whole-body air-displacement plethysmography. International journal of obesity and related metabolic disorders : journal of the International Association for the Study of Obesity 25, 1161-1167 (2001).

20. Wells, J.C. \& Fewtrell, M.S. Measuring body composition. Archives of disease in childhood 91, 612617 (2006).

21. Fields, D.A. \& Allison, D.B. Air-displacement plethysmography pediatric option in 2-6 years old using the four-compartment model as a criterion method. Obesity (Silver Spring) 20, 1732-1737 (2012).

22. Ma, G., et al. Validation of a new pediatric air-displacement plethysmograph for assessing body composition in infants. Am J Clin Nutr 79, 653-660 (2004). 


\section{Chapter 1}

23. Collins, A.L. \& McCarthy, H.D. Evaluation of factors determining the precision of body composition measurements by air displacement plethysmography. European journal of clinical nutrition 57,770 776 (2003).

24. Sheldon, W.H. The Varieties of Human Physique. New York: Harper \& Brothers(1940).

25. Tanner, J.M. \& Weiner, J.S. The reliability of the photogrammetric method of anthropometry, with a description of a miniature camera technique. American journal of physical anthropology 7, 145-186 (1949).

26. Dupertuis, C.W. \& Tanner, J.M. The pose of the subject for photogrammetric anthropometry, with especial reference to somatotyping. American journal of physical anthropology 8, 27-48 (1950).

27. Tanner, J.M. Current advances in the study of physique. Photogrammetric anthropometry and an androgyny scale. Lancet (London, England) 1, 574-579 (1951).

28. Han, K., Kwon, H.J., Choi, T.H., Kim, J.H. \& Son, D. Comparison of anthropometry with photogrammetry based on a standardized clinical photographic technique using a cephalostat and chair. J Craniomaxillofac Surg 38, 96-107 (2010).

29. Saad, K.R., Colombo, A.S. \& João, S.M.A. Reliability and validity of the photogrammetry for scoliosis evaluation: a cross-sectional prospective study. J Manipulative Physiol Ther 32, 423-430 (2009).

30. Anic-Milosevic, S., Mestrovic, S., Prlić, A. \& Slaj, M. Proportions in the upper lip-lower lip-chin area of the lower face as determined by photogrammetric method. J Craniomaxillofac Surg 38, 90-95 (2010).

31. Shaner, D.J., Bamforth, J.S., Peterson, A.E. \& Beattie, O.B. Technical note: Different techniques, different results--a comparison of photogrammetric and caliper-derived measurements. American journal of physical anthropology 106, 547-552 (1998). 




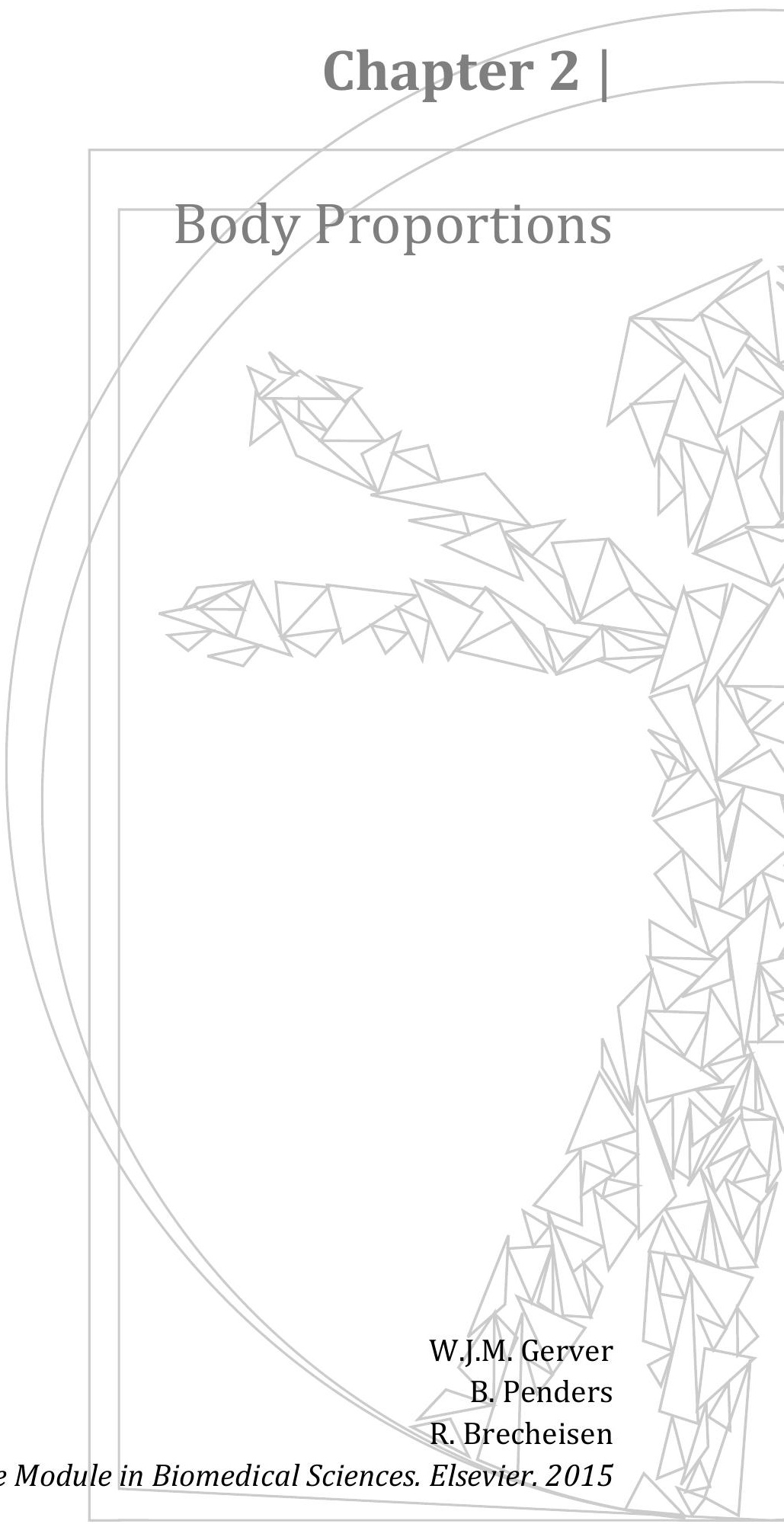

Reference Module in Biomedical Sciences. Elsevier. 2015 



\section{General Introduction}

In 1943, Medawar gave a clear description of the transformation that occurs during growth, showing the head-trunk-legs gradient, which indicates that the development of the head is advanced over that of the trunk and the development of the trunk is advanced over that of the legs during the maturation process. This clearly shows that the growth of different parts of the body does not occur simultaneously or at the same speed. In a child, this transformation can be defined by the interrelationship of a number of linear measurements, such as sitting height to full height, or head circumference to crown rump length. The ease with which one can equate the human body's shape with an accurate estimate of human age whether the compactness of a 5 year old, the coltishness of a young teenager, or the dimensions of a mature adult tends to be taken for granted. Nevertheless, this feat is remarkable. Even more extraordinary is the precision with which the human eye registers any deviation from the norm. The mathematical expression of these perceptions for scientific purposes is a highly complex task with imperfect results. Vital information is lost. It is possible, however, to use a reference population to organise the complexity of what even the untrained eye perceives naturally. Knowledge of the body proportions gives insight into the natural process of maturation and any disturbance will be visible in abnormal body proportions. A principal distinction can be made between a child with stunted growth affecting the whole body or affecting just some body parts. Such an observation leads to different conclusions about the origin of some growth deviation.

There are different possibilities of taking measurements in children. The first method is the classical one by means of a stadiometer, measuring rod or tape. Another method is photometry or body scanning. An outline of the photometry is programmed at the Maastricht University and presented below.

In this article, an overview is given of different techniques for taking bodily measurements. The reference values are based on a Dutch study of 2001, presented in the Atlas of Paediatric Morphometrics by Gerver and de Bruin. Of the 20 measurements taken in the Dutch study, the most important are selected for discussion here. 


\section{Anthropometry}

\section{Length and height}

In paediatrics, the curve representing a child's increase in height with age is used as one of the indicators of the child's health. The child's height is compared to that of a reference population in order to judge whether the child is atypical in terms of the height distribution of this population. Child and reference population must share the same geographical and socioeconomic background. Also, parental or familial height should be taken into consideration to assess the relative contribution of genetic and other factors to the child's height at any particular age.

Since growth is a dynamic process, one isolated measurement in time is meaningless for judging growth. Repeated measurements are needed to calculate the growth velocity. Knowledge of growth velocity is particularly relevant when dealing with a sick child. Depressed growth velocity may indicate the severity of an illness, whereas normalization of growth velocity or catch-up growth may signal recuperation.

Height is the distance between the top of the head and the sole of the foot. This distance is the sum of the height of the skull, the length of the spine, and the length of the lower extremities. Each of these different parts of the body have their own age-dependent growth velocity. Therefore, height is the result of the sum of different values, which are not linearly related in time.

\section{Method of measurement}

The distance between the top of the head and the sole of the foot is called length when an individual is measured lying down and height when the individual is measured standing upright.

Height is measured using a stadiometer. The stadiometer comprises a rigid vertical backboard and a horizontal headboard running free, perpendicular to the backboard and without cross-play. The top of the head must be in contact with the headboard. A $0.5 \mathrm{~kg}$ weight is placed on the headboard. This serves the purpose of flattening the child's hair and frees the physician's hands so as to enable him to keep the child in the correct upright position.

To measure standing height, the subject's shoes and socks are removed. The child is placed so that his heels, buttocks, and shoulders are in contact with the vertical plane of the stadiometer. The child's feet must be flat against the floor while either ankles or knees remain in contact. The child's head is held in the 'Frankfurt plane': the lower borders of the orbits are in the same horizontal plane as the external auditory meati. The measurement is taken while a gentle upward pressure is 
exerted on the mastoid processes so that the child is fully extended. In older children, stretching is achieved by telling them to breathe deeply.

To measure supine length, a measuring table resembling a stadiometer is used but on a horizontal plane. The headboard is fixed and the footboard is movable. Both the headboard and the footboard must be large enough to ensure that both the top of the head and the feet are in contact with them. To measure supine length, two people are necessary: one holds the infant's head in the vertical Frankfurt plane while at the same time another individual keeps the child's legs straight. The child's shoulders and buttocks must be in contact with the table. Supine length is measured in the first 2 years of age.

\section{Crown rump length, sitting height, and subischial leg length}

As stated earlier, height defined as the distance between the top of the head and the sole of the foot is the result of the sum of different values, which are not linearly related in time. Therefore, the first step is to split height into its different components. Generally, sitting height is taken as one of the components and compared to height. The relationship between sitting height and height is often expressed as an age-dependent ratio.

\section{Method of measurement}

The distance between the top of the head and the buttocks is called sitting height when the measurement is taken of a child sitting upright and is called crown rump length when an infant is measured lying down.

Sitting height is measured using a sitting height table. The table comprises a rigid vertical backboard and a horizontal headboard running free perpendicular to the backboard and without cross-play. The surface of the headboard must be in contact with the top of the head. A $0.5 \mathrm{~kg}$ weight is placed on the headboard. This weight flattens the child's hair and also frees the physician's hands so as to be able to keep the child in the correct position. The child must be in the sitting position with his feet on a footrest so that his full weight is on his buttocks. Insofar as is possible, arching of the back is avoided by gently applying upward pressure to the mastoid processes. In older children, stretching of the back is achieved by asking them to breathe deeply. The child's head is held in the Frankfurt plane: the lower borders of the orbits are in the same horizontal plane with the external auditory meati.

The recommended instrument for measuring crown rump length is similar to the stadiometer used for supine length. The headboard is fixed and the footboard is movable. Headboard and footboard must be large enough to ensure that the most protruding points of both head and buttocks are in contact with the boards. In order to measure this length, an assistant holds the infant's head in the vertical Frankfurt 


\section{Chapter 2}

plane while the physician holds the child's legs at a $90^{\circ}$ angle with the table. When this is achieved, the footboard is pressed against the buttocks.

Subischial leg length is defined as the arithmetic difference between height and sitting height or between supine length and crown rump length.

\section{Head circumference}

The head circumference is routinely measured in newborn infants since it correlates well with skull volume. Skull volume is highly correlated with gestational age, body weight, and body length. Since in intrauterine growth retardation, the brain is less affected than the weight and the length, the extent of the discrepancy between these measurements in the newborn will be an indicator of the severity of the retardation.

Because of the high growth velocity of the head circumference, especially during the first year of life, its measurement provides important information about the general condition of the child. In full-term healthy newborns, the head circumference increases approximately $1 \mathrm{~mm}$ per day initially.

\section{Method of measurement}

To measure head circumference, a fiberglass-reinforced tape of nonstretchable material is used. The tape is placed around the head at the most protruding points of occiput and forehead. In younger children, the tape is placed just above the brow ridges. The tape is placed gently so as to leave no marks after removal.

\section{Limb length}

The measurement of the limbs so as to describe body proportions is an important tool when evaluating development.

Arm span is the most common way to measure upper limb length. However, by measuring the span of the out-stretched arms from the tips of the longest fingers, the distorting information of the width of the trunk is added. What is required, however, is information on the growth of the long bones alone. Furthermore, the long bones of arms and legs can be accurately measured because of its bony marks. Hands and feet mature at an earlier age than other parts of the body. Therefore, the changing relationship of hands and feet to height is a useful criterion of the maturation of the child. 


\section{Method of measurement}

To measure arm span, a measuring rod can be used. Standing with the arms fully extended, the distance between the tips of the stretched middle fingers is measured. To measure the different parts of the arm, the arm should be relaxed and extended along the child's side. The bony prominences are used as anatomical landmarks. To measure the upper arm length, the lateral border of the acromion and the proximal head of the radius are palpated distal to the lateral epicondyle of the humerus. To measure the lower arm length, the proximal and distal heads of the radius are used. These landmarks are marked with a pen and the distance between them is measured. To measure the length of the hand, the distance between the tip of the longest finger and the distal head of the radius is measured with the hand and forearm flat on a table.

For tibia length, the distance between the proximal-medial border of the tibia and the distal border of the medial malleolus is measured with the Harpenden anthropometer.

The foot is measured while the child is standing. The distance between the most posterior part of the heel and the tip of the longest toe, normally the first toe, is measured on the left foot.

\section{Biacromial width and biiliacal width}

Puberty is characterised auxologically by increasing width of shoulders and hips.

The ratio of biacromial width to biiliacal width is a good index of sexual maturation. Biacromial and biiliacal width curves remain almost identical in both sexes until puberty. The increase of the biacromial width during puberty is more striking in boys than in girls. The change of the ratio between biacromial and biiliacal width signals the onset of puberty.

\section{Method of measurement}

With the Harpenden anthropometer, measurements of shoulder widths and pelvic widths are taken. When the child relaxes its shoulders, the distance between the most lateral borders of the acromial processes is measured to obtain the biacromial width.

To measure the biiliacal width, the branches of the anthropometer are moved over the iliac crests at their widest point and the distance between the two blades of the anthropometer is measured. In children aged 0-1 year, it is not always possible to take these measurements because of unrest or obesity. Also, in older children, the biiliacal width is hard to obtain in the case of obesity. 


\section{Photometry}

\section{Introduction}

Manual measurement of body dimensions has been common practice for a long time. However, it is a highly time-consuming procedure requiring a variety of measurement tools and the skills to use them. Even though it is likely to remain the golden standard for some time to come, alternative methods exist that allow for much faster measurement of body dimensions. One of the most promising of these methods is photometry that involves measurement of body dimensions on the basis of digital images. The overall procedure exists in taking a frontal and lateral picture of the standing subject, importing these pictures into photometry software and measuring the body part dimensions by selection anatomical points in the pictures.

The main advantages of the photometry method are (1) speed, (2) ease of use and (3) flexibility. After taking the pictures, the whole procedure can be done in a few minutes by anyone with the required knowledge about the correct locations of each anatomical point. To support the localisation of these points, an example image where the correct point locations are highlighted, can be given. The flexibility of the method follows primarily from the separation of the procedure into multiple steps that can be performed at different points in time and place. The actual presence of the subject is only needed during the photography session.

Transfer of the pictures and selection of anatomical points can all be done at a time most convenient for the measurer. Pictures are stored in digital format so they can be easily transferred across a computer network to a remote location for further processing.

In most cases a professional photographer will perform the photography. However, given some assistance this is also feasible for lay people, e.g., parents taking pictures of their children.

\section{Method of measurement}

The first step of the photometry method involves photography of the subject together with a reference object of known length or size. Two pictures are taken, one frontal and one lateral. The lateral picture is needed to measure foot length. The remaining lengths are measured in the frontal picture. The reference object can be a vertical rod or a square mat of known size lying on the floor. It is needed in order to determine the correspondence between pixels in the image and length in centimetres. Once this correspondence has been established the user can select the end-points of each body part (in pixel coordinates) after which the application automatically calculates the distance in centimetres (see Figure 1). 

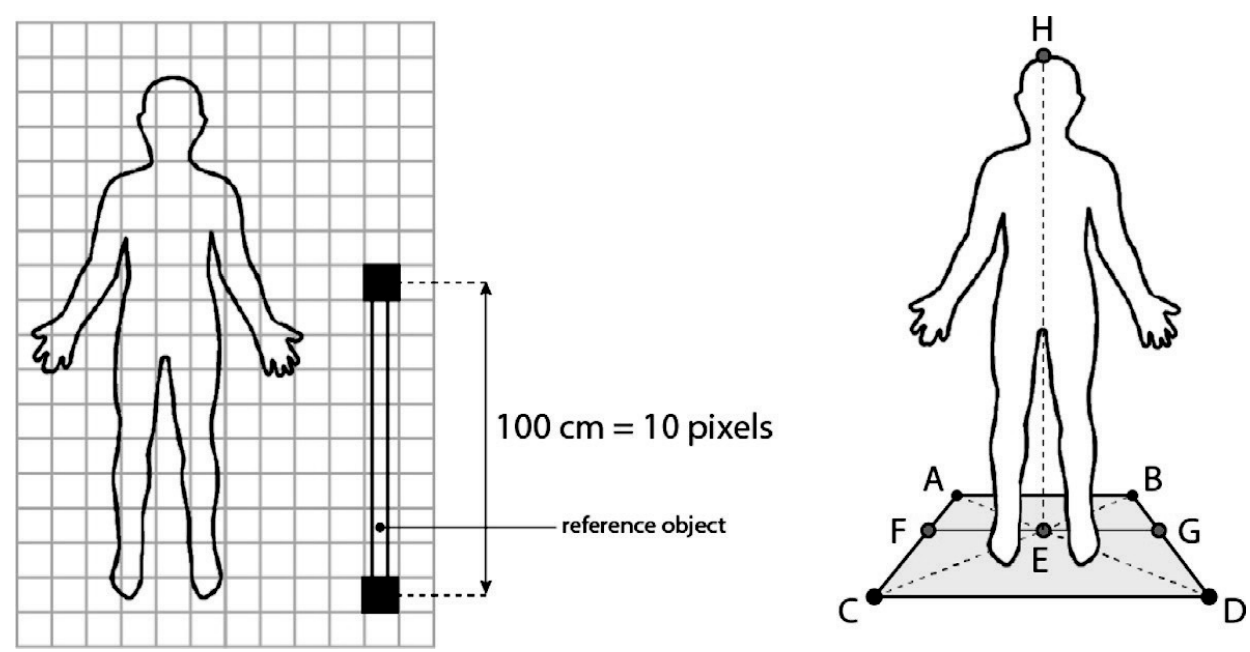

Figure 1 | Calculating centimetres per pixel using a vertical reference object (left) or a square mat (right). Using the corner points A, B, C and D the intersection point $\mathrm{E}$ is calculated first, followed by the distance F - G in pixels. Since F - G is also known in centimetres, the centimetres per pixel ratio is obtained. To determine total body height only point $\mathrm{H}$ has to be manually selected (point $\mathrm{E}$ is calculated automatically)

When the user has finished measuring the body dimensions, the measurements can be saved. The user can easily perform and save additional measurements for the same subject in order to capture changes in body proportions over time. These measurements can be visualised inside the different growth curves commonly used in the Paediatric Morphometrics atlas (see Figure 2).

\section{Calculating centimetre-per-pixel ratio}

Since point selections on a computer screen are defined in pixel coordinates, a conversion from pixels to centimetres must be performed. Calculating the pixel-tocentimetre ratio is trivial for a vertical rod of known length (see Figure 1 left). For the square mat this is slightly more involved and requires a number of steps (see Figure 1 right). Using basic geometry the intersection point $\mathrm{E}$ can be calculated from the four corner points A, B, C and D. Similar intersection calculations give us the distance $\mathrm{F}$ - $\mathrm{G}$ in pixels which together with the known length in centimetres gives us a pixel-to-centimetre ratio. Since point $\mathrm{E}$ was calculated automatically the user only has to select point $\mathrm{H}$ in order to determine total body height. 


\section{Calculating shape ages}

The photometry software also allows for automatic calculation of shape ages. This is the age the subject would have if his or her body measurement is considered to be average (i.e., at the p50 level). For example, consider Figure 2 where the growth curves represent height as a function of age at various p-values. The highlighted square represents a particular height measurement for a subject of about 10.5 years old. This particular subject's shape age can be found by tracing a horizontal line from the highlighted square to the left until it intersects the p50 curve. At the intersection point a line is traced vertically downwards to find a shape age of 8 years for this subject. Using the photometry software, the shape age can be calculated automatically. Note that shape ages always correspond to a specific measurement, such as height. They do not necessarily represent a general characteristic, such as prematurity, of the subject.

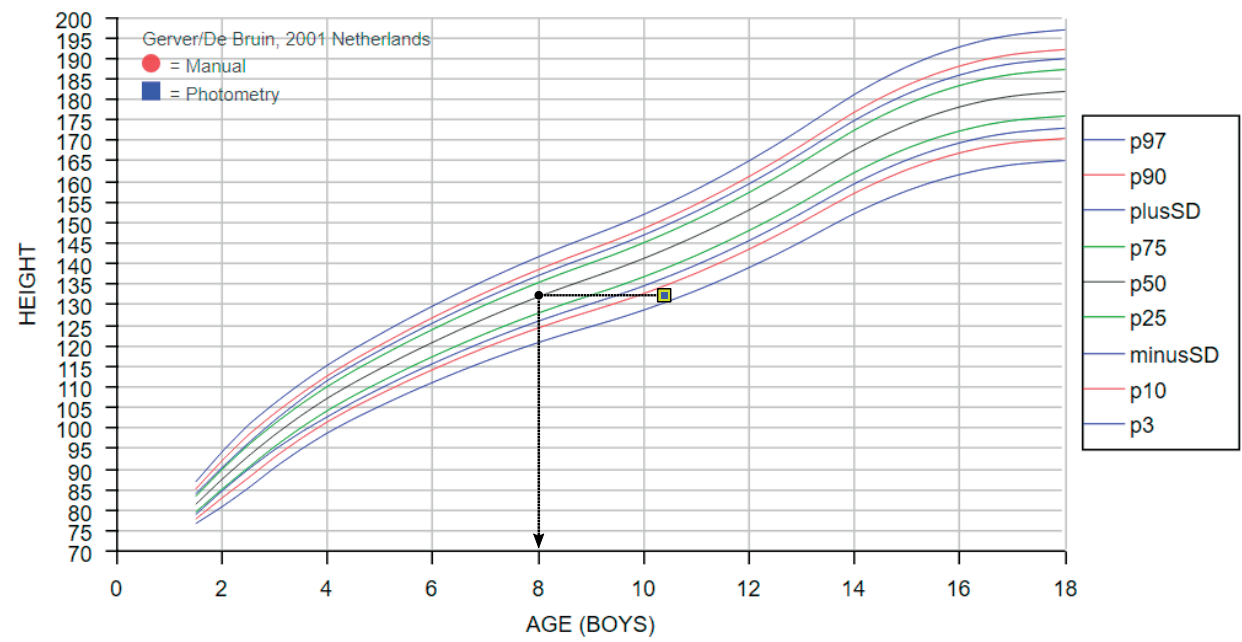

Figure 2 | Growth curve height for age overlaid with a single measurement (highlighted square)

\section{Interpretation of Body Proportions}

To judge the body proportions of an individual, one can make use of three different expressions:

- $\quad$ One can take the ratio of two measurements such as sitting height divided by height, or even better the subischial leg length divided by sitting height. Ratios are age-dependent and the curve changes in time. However, the use of ratios can be misleading for two reasons: first, two ratios may be equal, while their nominators and denominators are not; and second, when a change in the nominator automatically leads to a change in the denominator, the change of the ratio will be even more misleading. 
- A more straightforward approach is to simply plot one measurement against another. One can plot height against sitting height, however, the preferred method would be to use sitting height and subischial leg length as measurements for comparison, since these are independent variables. A change in sitting height will automatically induce a change in height, but not a change in subischial leg length. In the same way a number of measurements can be compared to each other such as foot length to height, head circumference to supine length, arm span to height, biacromial to biiliacal diameter, and upper arm to lower arm.

- $\quad$ One can calculate the typicality or atypicality of an individual by means of the squared distance $D^{2}$, which follows a chi square distribution if normal children are considered.

First one calculates the standard deviation score, $\mathrm{z}(\mathrm{t})$, of each measurement by:

$$
z(t)=\frac{x(t)-\mu(t)}{\sigma(t)}
$$

where $x(t)$ denotes the individual's body measurement score at age $t$ (e.g., height), $\mu(t)$ denotes the population mean at age $t$, and $\sigma(t)$ denotes the corresponding standard deviation of the population.

Second, the squared distance $D^{2}$ is calculated as follows:

$$
D^{2}=\left[1-r_{(h, s h)}^{2}\right]^{-1} \cdot\left[z_{h}^{2}+z_{\mathrm{sh}}^{2}-2 z_{h} \cdot z_{\mathrm{sh}} \cdot r_{(h, s h)}^{2}\right]
$$

where $r$ denotes the correlation coefficient of the two measurements height $(\mathrm{h})$ and sitting height (sh) according to Table 1.

$D^{2} \leq 5.991$ indicates that the considered individual is typical or normal, whereas $D^{2}$ $\geq 5.991$ suggests that something is wrong with size and/or shape.

Graphically, one can display the atypicality of a particular individual by constructing an ellipse, which comprises $95 \%$ of the pairs of scores (Figure 3). 


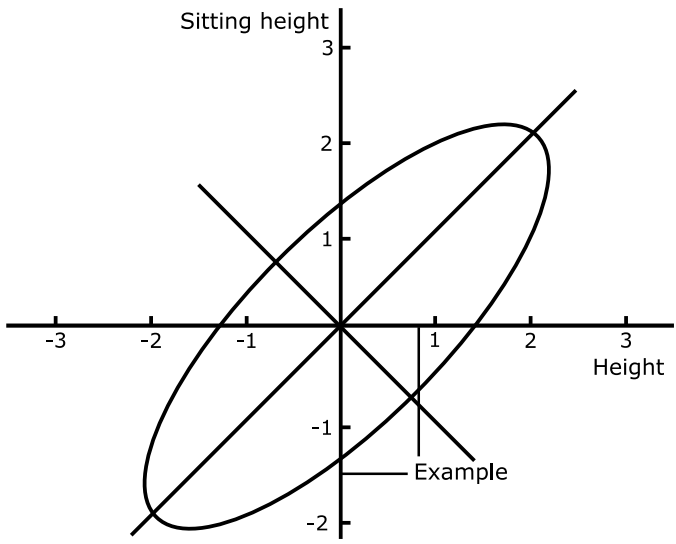

Figure 3 | The 95\% confidence limits of the pair of z-scores of height and sitting height. The example is the patient mentioned in the text with the consequence that the two scores considered together indicate atypicality

\section{Example}

If a boy of 6.5 years has a height of $134.6 \mathrm{~cm}$ and a sitting height $63.5 \mathrm{~cm}$, the corresponding $\mathrm{z}$-scores for height and sitting height are $\mathrm{zh}_{\mathrm{h}}=0.92$ and $\mathrm{z}_{\mathrm{sh}}=-1.5$.

These scores considered separately do not indicate that something is wrong with this child. The difference in sign, however, is somewhat alarming because the correlation between the measurements is positive. Using the value 0.82 for the correlation coefficient between height and sitting height (Table 1), one obtains:

$$
\frac{\left|z_{h}-z_{\text {sh }}\right|}{\left[2+2 r_{(h, s h)}\right]^{\frac{1}{2}}} \geq 1.960=16.05
$$

$$
\geq \chi_{2.05}^{2}=5.991
$$

This is interesting because, as discussed earlier, separate considerations did not indicate sufficient evidence of abnormality.

Table 1 | Correlation coefficient of pairs of measurements of body proportions according to sex

\begin{tabular}{llll}
\hline & Boys & Girls & Mean \\
\hline Height / arm span & 0.87 & 0.85 & 0.86 \\
Height / sitting height & 0.82 & 0.82 & 0.82 \\
Height / tibia length & 0.80 & 0.80 & 0.80 \\
Height / foot length & 0.75 & 0.66 & 0.70 \\
Height / hand length & 0.76 & 0.64 & 0.70 \\
Biacromial / biiliacal diameter & 0.60 & 0.50 & 0.55
\end{tabular}

Note: These correlations are almost independent of age for children between the ages of 3 and 17 years 


\section{Conclusion}

Paediatricians are often confronted with children of all ages who are referred for growth problems, such as growth retardation or dimorphism. One of the incentives of this article was to provide methods that will give the possibility of discerning growth variation according to typical or atypical patterns. Besides the techniques of measuring children manually also a new method is presented by means of photometry. It provides the possibility to be informed about the proportions of a child based on several measurements within a short time.

\section{References}

For the reference values used, one is referred to the Atlas:

Paediatric Morphometrics: A Reference Manual

W.J.M. Gerver and R. de Bruin

Second edition 2001

University Press Maastricht, The Netherlands

ISBN 9052783071, 9789052783079 



\section{Chapter 3}

Validating Paediatric Morphometrics: body proportion measurement using photogrammetric anthropometry

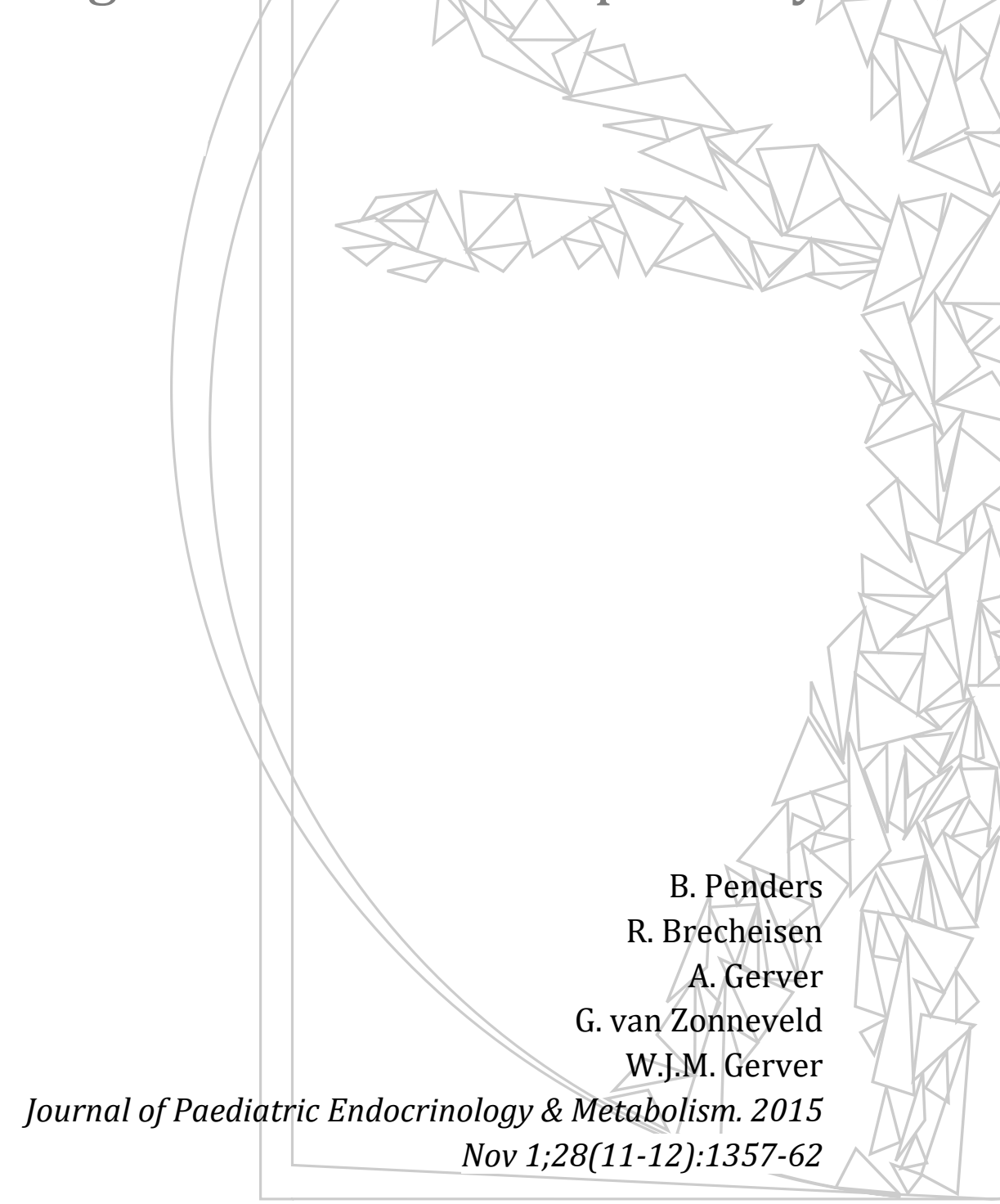




\section{Abstract}

\section{Background}

Taking multiple anthropometric measurements for the description of body proportions in an accurate way, is a time-consuming procedure that requires specific tools and skills. This is why we developed an alternative method based on digital photography for taking these measurements which is faster and easier to use, to make anthropometry more user-friendly and approachable to paediatricians.

\section{Methods}

We conducted a cross-sectional study in 54 children between 2 and 18 years of age. We compared manual measurements with photogrammetric measurements to validate our method.

\section{Results}

Inter-observer correlations of all measurements are $\geq 0.96$ and mean differences are 0.3-0.9 cm, except for arm span. Comparison of manual to photogrammetric measurements shows mean differences of $0.6-1.3 \mathrm{~cm}$, with correlations $\geq 0.92$, except for sitting height and arm span. Correlations of ratios between methods are height / sitting height $(r=0.77)$, biacromial width / biiliacal width $(r=0.74)$ and subischial leg length / sitting height $(r=0.75)$.

\section{Conclusion}

Photogrammetric anthropometry is fast, easy to use and provides the paediatrician with more flexibility as taking the digital photographs and performing the analysis are separated. 


\section{Introduction}

Measurement of height is used in daily practice of paediatrics to monitor growth as a parameter of health and development in childhood. However, the growth process is not only characterised by an increase in height, but also by a constant change in body proportions due to varying rates and times of growth of different parts of the body.

In the field of endocrinology and clinical genetics, elaborate measurements of the human body are more often performed to detect syndromes and pathological growth patterns ${ }^{1,2}$. Besides being important for diagnosis, description of body proportions is also used to evaluate a possible effect of treatment ${ }^{3-5}$. However, taking multiple anthropometric measurements accurately, is a time-consuming procedure that requires specific tools and skills; the measurement of height is often the only anthropometric measurement commonly performed.

To make anthropometric measurement of children faster and easier, and therefore more approachable to paediatricians, we developed an alternative method by means of digital photography. Already in 1951, Tanner used photogrammetric anthropometry as a means of classifying physique, but the use of photographs for anthropometric measurements has been scarce and mainly focussed on facial description in clinical genetics and scoliosis evaluation in orthopaedics ${ }^{3,5-9}$.

In this study, we present photogrammetric anthropometry as an alternative measuring method to monitor the growth of a child in its constant changing proportions. We used the specialised photometry software, Paediatric Morphometrics, designed by our research group, to perform the photogrammetric measurements.

\section{Methods}

The following cross-sectional study was designed to evaluate and validate the photogrammetric measurement method.

\section{Study groups}

Two groups of outpatients between 2 and 18 years of age, visiting the Maastricht University Medical Centre (MUMC+), were included in this study. Before inclusion, all patients and/or their parents had given an informed consent. In accordance with Dutch law, this study did not need to be approved by an institutional review board.

Manual measurements were taken of all patients using the Harpenden anthropometer (Holtain Ltd, Crosswell, UK) conform a standardised technique ${ }^{1}$. The measurements included height, sitting height, arm span, biacromial width, biiliacal width, upper arm length, lower arm length, hand length and foot length. 
The first study group consisted of 33 patients and was used to assess inter-observer correlation for the manual measurements taken by two trained anthropometrists. The digital photographs of these children were used in the development of the photometry software. After development was complete, a second study group of 21 patients was used to assess comparability between the manual and photogrammetric measurements. One trained anthropometrist manually measured these patients. Digital photographs were taken and two trained anthropometrists performed the photogrammetric measurements independently. The results of these measurements were compared.

\section{Photogrammetric method}

The clinical photographs were taken by the Medical Photography Unit of the academic hospital with a Canon EOS 70D digital camera and a lens with a set focal length of $50 \mathrm{~mm}$ to minimise lens distortion. The camera was positioned at a fixed distance of $4 \mathrm{~m}$ from the subject. The children were photographed in standard anatomical position against a fixed backboard (Figure 1). Heels, buttocks and head were positioned touching the backboard; heels or knees were kept together and the head was positioned in the "Frankfurt plane": the lower borders of the orbits are positioned in the same horizontal plane as the external auditory meati. Optimal stretching was achieved by asking the children to take a deep breath at the moment the photograph was taken.

As a reference measure, a grid of known size fixed to the backboard was used. A reference measure is needed in order to determine the correspondence between pixels in the photograph and length in centimetres of the measurements. A lateral photograph was used to measure foot length; all other measurements were performed in the frontal photograph. The photographs were imported to the Paediatric Morphometrics software.

The measurements of height, biacromial width, biiliacal width, upper arm length, lower arm length, hand length and foot length were performed by selecting the anatomical reference points in the photographs also used in the manual measurements. The Paediatric Morphometrics software automatically calculates the distances between the selected points. 


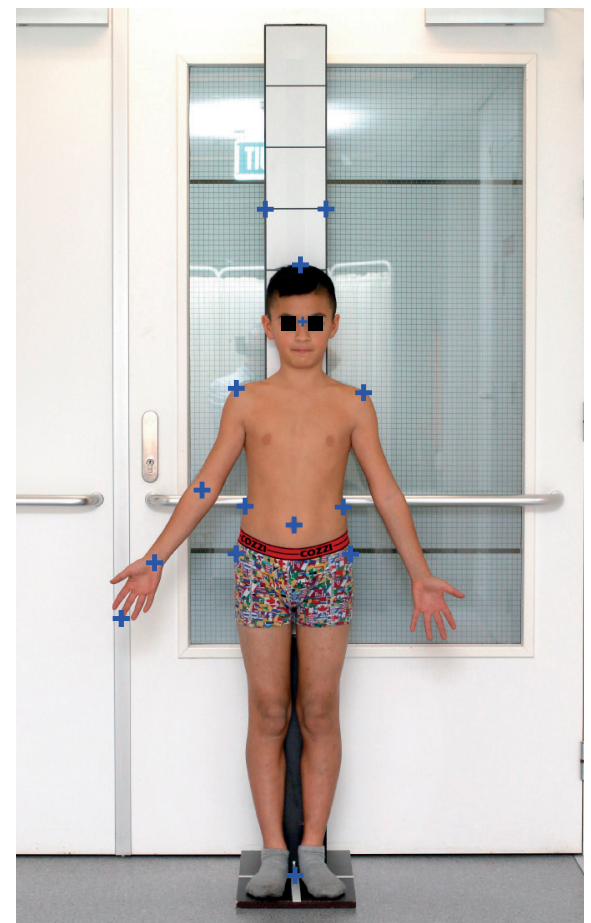

Figure 1 | Positioning of the subject and reference measure and selection of measurements

Total sitting height cannot be allocated with the use of anatomical reference points in a frontal photograph. Therefore, this measurement was estimated by using just a part of the sitting height distance that can be selected accurately in the frontal plane, namely the distance between the nasal root and the umbilicus ( $\mathrm{NaUm}$ ), adapted by the linear regression formula:

$$
S H_{p h}=1.28 \cdot \mathrm{NaUm}+13.7
$$

where $S H_{p h}$ is the calculated sitting height in the photograph in centimetres and $\mathrm{NaUm}$ is the distance between the nasal root and the umbilicus in centimetres $\left(r^{2}=\right.$ 0.94).

Because arm span is measured in a different position manually than in the photograph, the arm span is estimated using the formula:

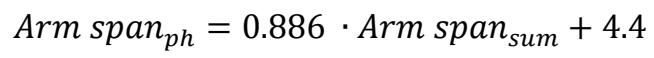

where Arm span ph is the calculated arm span in the photograph in centimetres and Arm span $_{\text {sum }}$ is the sum of the biacromial width plus two times the length of the upper arm, lower arm and hand in centimetres $\left(\mathrm{r}^{2}=0.98\right)$.

Three ratios commonly used in anthropometry were calculated for the manual measurements as well as for the photogrammetric measurements. These ratios 


\section{Chapter 3}

included sitting height / height $(S H / H)$, biacromial width / biiliacal width (Biac/Bill) and subischial leg length / sitting height $(L L / S H)$.

\section{Statistical analysis}

Measurements were saved and exported for statistical analysis to IBM SPSS Statistics for Windows, Version 20.0. Shapiro-Wilk tests were performed for all the measurements to test for normality. Inter-observer correlation was determined with Pearson's correlation coefficient and the two measurement methods were compared by calculating the mean differences with standard deviation and correlation.

\section{Results}

Table 1 shows the inter-observer mean differences in centimetres for the manual measurements. Manual measurements by the two observers BP and WJMG were compared. Height, sitting height and arm span were manually measured by one observer and are not shown in this table. The biggest difference between the observers is seen in the measurement of the upper arm. The mean inter-observer differences for the manual measurements are between 0.3 and $0.7 \mathrm{~cm}$. The interobserver correlations are $\geq 0.98$ ( $p \leq 0.001$ ) for all manual measurements.

Table 1 | Inter-observer results for the manual measurements

\begin{tabular}{lcc}
\hline Measurement $(\mathrm{n}=33)$ & Mean diff. $(\mathrm{cm}) \pm S D$ & $r$ \\
\hline Biacromial width & $0.6 \pm 0.5$ & $0.99(\mathrm{p} \leq 0.001)$ \\
Biiliacal width & $0.5 \pm 0.4$ & $0.98(\mathrm{p} \leq 0.001)$ \\
Upper arm length & $0.7 \pm 0.5$ & $0.98(\mathrm{p} \leq 0.001)$ \\
Lower arm length & $0.4 \pm 0.3$ & $0.98(\mathrm{p} \leq 0.001)$ \\
Hand length & $0.3 \pm 0.2$ & $0.99(\mathrm{p} \leq 0.001)$ \\
Foot length & $0.4 \pm 0.3$ & $0.99(\mathrm{p} \leq 0.001)$ \\
\hline
\end{tabular}

The inter-observer results for the photogrammetric measurements are shown in Table 2. All measurements show a mean difference between 0.4 and $0.9 \mathrm{~cm}$, except for arm span. The inter-observer correlations are $\geq 0.96(\mathrm{p} \leq 0.001)$ for all photogrammetric measurements. 
Table 2 | Inter-observer results for the photogrammetric measurement

\begin{tabular}{lcc}
\hline Measurement $(\mathrm{n}=21)$ & Mean diff. $(\mathrm{cm}) \pm S D$ & $r$ \\
\hline Height & $0.7 \pm 0.5$ & $0.99(\mathrm{p} \leq 0.001)$ \\
Sitting Height & $0.4 \pm 0.3$ & $0.99(\mathrm{p} \leq 0.001)$ \\
Arm span & $2.0 \pm 1.7$ & $0.99(\mathrm{p} \leq 0.001)$ \\
Biacromial width & $0.9 \pm 0.7$ & $0.98(\mathrm{p} \leq 0.001)$ \\
Biiliacal width & $0.6 \pm 0.5$ & $0.98(\mathrm{p} \leq 0.001)$ \\
Upper arm length & $0.9 \pm 0.6$ & $0.99(\mathrm{p} \leq 0.001)$ \\
Lower arm length & $0.8 \pm 0.4$ & $0.99(\mathrm{p} \leq 0.001)$ \\
Hand length & $0.4 \pm 0.4$ & $0.96(\mathrm{p} \leq 0.001)$ \\
Foot length & $0.4 \pm 0.4$ & $0.99(\mathrm{p} \leq 0.001)$ \\
\hline
\end{tabular}

Table 3 shows the comparison of the manual measurements to the photogrammetric measurements. The comparison of these measurements was done for each observer separately. The biggest differences are seen in the measurement of sitting height and arm span. Both measurements were calculated with the aid of the formulae as explained in the methods. The photogrammetric measurement of the sitting height yields a mean difference to the manually measured sitting height of $1.9 \mathrm{~cm}$. The mean difference between the manual measurement and photogrammetric measurements of the arm span is $2.1 \mathrm{~cm}$. All other measurements show mean differences between 0.6 and $1.3 \mathrm{~cm}$. Correlations between all manual and photogrammetric measurements are $\geq 0.91(p \leq 0.001)$ for both observers.

Table 3 | Comparison of manual to photogrammetric measurements

\begin{tabular}{lcccc}
\hline & \multicolumn{2}{c}{ Observer 1} & \multicolumn{2}{c}{ Observer 2} \\
Measurement $(\mathrm{n}=21)$ & Mean diff. (cm) \pm SD & $r$ & Mean diff. (cm) \pm SD & $r$ \\
\hline Height & $0.8 \pm 0.5$ & $0.99(\mathrm{p} \leq 0.001)$ & $0.9 \pm 0.5$ & $0.99(\mathrm{p} \leq 0.001)$ \\
Sitting Height & $1.9 \pm 1.5$ & $0.97(\mathrm{p} \leq 0.001)$ & $2.0 \pm 1.5$ & $0.97(\mathrm{p} \leq 0.001)$ \\
Arm span & $2.1 \pm 2.2$ & $0.99(\mathrm{p} \leq 0.001)$ & $2.2 \pm 2.0$ & $0.99(\mathrm{p} \leq 0.001)$ \\
Biacromial width & $0.6 \pm 0.4$ & $0.99(\mathrm{p} \leq 0.001)$ & $1.0 \pm 0.7$ & $0.97(\mathrm{p} \leq 0.001)$ \\
Biiliacal width & $0.9 \pm 0.4$ & $0.99(\mathrm{p} \leq 0.001)$ & $1.3 \pm 0.7$ & $0.97(\mathrm{p} \leq 0.001)$ \\
Upper arm length & $0.6 \pm 0.5$ & $0.99(\mathrm{p} \leq 0.001)$ & $0.8 \pm 0.6$ & $0.99(\mathrm{p} \leq 0.001)$ \\
Lower arm length & $0.8 \pm 0.7$ & $0.95(\mathrm{p} \leq 0.001)$ & $1.2 \pm 0.8$ & $0.93(\mathrm{p} \leq 0.001)$ \\
Hand length & $0.7 \pm 0.6$ & $0.92(\mathrm{p} \leq 0.001)$ & $0.8 \pm 0.6$ & $0.91(\mathrm{p} \leq 0.001)$ \\
Foot length & $0.8 \pm 0.4$ & $0.99(\mathrm{p} \leq 0.001)$ & $1.0 \pm 0.5$ & $0.99(\mathrm{p} \leq 0.001)$ \\
\hline
\end{tabular}

The ratios of $S H / H, B i a c / B i i l$ and $L L / S H$ were calculated and comparison of the manual to photogrammetric ratios is shown in Table 4. Correlations between the manual and photogrammetric calculated ratios are $\geq 0.70(\mathrm{p} \leq 0.001)$ for both observers. 
Table 4 | Comparison of manual to photogrammetric ratios

\begin{tabular}{lcccc}
\hline Measurement $(\mathrm{n}=21)$ & \multicolumn{2}{c}{ Observer 1} & \multicolumn{2}{c}{ Observer 2} \\
& Mean diff. \pm SD & $r$ & Mean diff. \pm SD & $r$ \\
\hline SH/H & $0.01 \pm 0.01$ & $0.77(\mathrm{p} \leq 0.001)$ & $0.01 \pm 0.01$ & $0.76(\mathrm{p} \leq 0.001)$ \\
Biac/Biil & $0.06 \pm 0.04$ & $0.78(\mathrm{p} \leq 0.001)$ & $0.11 \pm 0.07$ & $0.70(\mathrm{p} \leq 0.001)$ \\
LL/SH & $0.05 \pm 0.04$ & $0.75(\mathrm{p} \leq 0.001)$ & $0.05 \pm 0.04$ & $0.75(\mathrm{p} \leq 0.001)$ \\
\hline
\end{tabular}

\section{Discussion}

In this study we developed a method to measure various body measurements and body proportions in children by using digital photography and the software needed to calculate the results. This method is principally based on selection of measurements in digital photographs and conversion of these measurements to actual centimetres by using a scale derived from a reference measure.

We found that there are three critical points that determine the reliability of photogrammetric measurements: the technique of photography, the positioning of both the child and the reference measure and the training of the observers.

\section{The technique of photography}

In collaboration with the Medical Photography Unit of the academic hospital several lenses and positions of the camera were evaluated. To apply photometry on digital photographs accurately, it is essential that lens and perspective distortions are minimised. The amount of lens distortion between photographs taken with a zoom lens and a lens with a fixed focal length of $50 \mathrm{~mm}$ was compared by using photographs of a grid structure. Various squares of the grid structure were measured in the photographs and compared mutually to assess possible size differences due to lens distortion. It was shown that lens distortion was virtually non-existent when a lens with a fixed focal length was used as opposed to the usage of a zoom lens. These lenses are part of the normal equipment of professional photographers working in most hospitals. Taking the photographs at a fixed distance of $4.0 \mathrm{~m}$ and adapting the height of the camera to the middle of the patient's body, eliminated perspective distortion.

\section{The positioning of the child and reference measure}

In the development of the photogrammetric measurement set-up, several reference measures and positions of the subject were evaluated: a pole beside the patient ( $\mathrm{n}=$ 9 ) or a square mat $(n=24)$ of known size on which the patient was photographed standing. These turned out to be less accurate than the current set-up in which the subject is placed against a fixed backboard or wall $(n=21)$ with a grid as reference measure on it. By positioning the patient against a fixed backboard with ankles or 
knees together and buttock and shoulders touching the backboard, with the head positioned in Frankfurt plane, it is made sure that the patient is standing straight. By asking them to breathe deeply, stretching of the spine is achieved. When stretching is not applied, deviation of height measurements as great as several centimetres can be seen.

\section{The training of the observers}

As stated by Tanner, "measurements of growth begin with modern well-maintained equipment and a trained technician using it" 10 , training of the observers is essential to yield accurate, reliable data in anthropometric research. In both anthropometry and photometry, knowledge of the location of bony landmarks is a prerequisite. However, the manner in which the landmarks are localised is different. In anthropometry, these landmarks can be palpated before measurements are taken. In photometry, the location of the landmarks has to be judged by eye. To help the observer in the selection of these landmarks, there is a built-in zoom function in the photometry program available. During the development of the Paediatric Morphometrics software, the observers defined the localisation of the anatomical landmarks in the photographs. The localisation of the biacromial and biiliacal landmarks was found to be the most difficult in the photograph, especially because in anthropometric measurement the soft tissue around these landmarks is compressed to perform these measurements accurately.

Besides these three factors that determine the reliability of photogrammetric measurement in general, additional procedures were needed to perform the measurement of height, sitting height and arm span in a digital photograph.

\section{Height}

The deviation between the manual and photogrammetric measurements of height can be explained by the difficulty of selecting the appropriate point of measurement on the head of the subject. The hair of the subject makes it difficult to ascertain the precise top of the head in a photograph. This difficulty does not occur when using a stadiometer. The most accurate solution was proven to be the selection of the top of the head where the backboard becomes visible. Selecting the height at this point yields a mean difference of $0.8 \pm 0.5 \mathrm{~cm}$ (Table 3 ).

\section{Sitting height}

In anthropometry, the correct method of determining the sitting height of a child is to use a sitting height table. To measure sitting height in a photograph, we analysed if this could be done accurately in a photograph of a child sitting down. This was not the case. Also, the sitting height cannot be measured directly in a frontal photograph 
of a standing subject, as there are no anatomical reference points visible. Therefore, the distance between the nasal root and umbilicus ( NaUm) was used as a part of the sitting height that can be selected accurately on a frontal photograph of a standing subject, provided that the patient's head is positioned in the Frankfurt plane.

By comparing the manually measured sitting height with the distance NaUm on the photograph, a linear regression formula is calculated and used to estimate the sitting height distance on the photograph. Calculation of the sitting height using this formula yields a mean difference to the manually measured sitting height of $1.9 \pm 1.5$ cm (Table 3).

\section{Arm span}

The difference seen in the arm span measurements between manual and photogrammetric measurement can be explained by the fact that manual measurement of the arm span conform the standardised techniques is done with the arms in horizontal plane, whereas arm span in the photogrammetric measurements is measured with the child in anatomical position ${ }^{1}$. Because of this, a different part of the trunk is measured as shoulder width. The arm span in the photograph is therefore calculated using the formula given in the methods. It leads to a mean difference between the photogrammetric and the manual measurement of $2.1 \pm 2.2$ cm (Table 3).

We chose not to take an additional photograph with the arms outstretched in horizontal plane, for practical reasons the distance from which the photographer would have to take the picture would become too great to fit in an average examination room and additional photographs require more time from the paediatrician for analysis, whereas the linear regression formula provides an acceptable estimation of the arm span.

\section{Comparison of anthropometry to photometry}

The estimation of the accuracy of anthropometric measurements or photogrammetric measurements is problematic, as the true value of any anthropometric measurement is disputable, as no anthropometric data are free from measurement errors ${ }^{11,12}$. The comparison of manual and photogrammetric measurements shows that the measurements of sitting height and arm span have the greatest differences between them. In all other measurements, the mean difference between both measurement techniques is $0.6-1.3 \mathrm{~cm}$ (Table 3). We find these differences acceptable to get an overview of the bodily measurements and proportions of a child. 


\section{Inter-observer correlations and mean differences}

Pearson's correlation coefficient can be used to compare inter-observer repeatability of anthropometric measurements. The inter-observer correlations for the manual measurements were $\geq 0.98(p \leq 0.001)$ (Table 1$)$ and $\geq 0.96(p \leq 0.001)$ (Table 2) for the photogrammetric measurements.

The correlations and mean differences seen in the manual and photogrammetric inter-observer measurements are fairly comparable. The biggest differences are seen in the measurements of biacromial width and the arm measurements.

\section{Ratios}

The reference curves of the $S H / H, L L / S H$ and Biac/Biil ratios show a standard deviation similar to the deviation seen between manual measurements and between manual to photogrammetric measurements ${ }^{1}$. This means that calculation of ratios based on photogrammetric or manual measurements is similar in precision. Interpretation of ratios remains difficult; a relatively small measurement deviation may lead to a ratio difference of around one standard deviation. However, ratios are useful to detect and quantify large proportional deviations.

\section{Conclusion}

In this study, we have shown that photometry as a method of measurement of the body proportions of a child can be done in an accurate and reliable way. The main advantages of photometry in comparison to manual anthropometry are as follows:

- $\quad$ Photometry reduces the time needed to perform multiple measurements and is easier to use, making it a serious consideration for large longitudinal studies.

- It provides the paediatrician with more flexibility as taking the digital photographs and performing the analysis are separated.

- With photometry, measurements of patients can be performed across the world without the need for the paediatrician to see them in person.

- $\quad$ Follow-up and comparing measurements are easier and multi-disciplinary evaluation of patients is feasible.

- Digital photographs can be taken by the parents of a child and sent to the paediatrician for taking measurements provided the parents are well instructed.

It was shown that the photogrammetric measurement of sitting height and arm span in a subject standing in anatomical position cannot be done directly. By means of linear regression, an estimation of the sitting height and arm span was calculated. However, the calculation of these measurements in the photographs and the manual measurements show the greatest differences between them. 


\section{Chapter 3}

With the development of this photogrammetric measurement method we aim to make anthropometry, especially the evaluation of body proportions, more approachable and user-friendly to paediatricians. We intend to make the photometry software available online with clear instructions for easy use in general paediatric practice.

\section{Acknowledgments}

The development of the photogrammetric software was supported by a grant from Ferring Pharmaceuticals. Special thanks go to Engelbert Schins of the Medical Photography Unit and Jelle Penders for critical review of the manuscript.

\section{Conflict of interest statement}

The authors have no conflicts of interest to disclose. 


\section{References}

1 Gerver, W. J. M. \& de Bruin, R. Paediatric Morphometrics: A Reference Manual. 3th edition, (Universitaire Pers Maastricht, 2011).

2 Gerver, W. J., de Bruin, R., Penders, B. \& Brecheisen, R. Body Proportions. Biomedical Reference Module, Elsevier (2014).

3 Farkas, L. G., Bryson, W. \& Klotz, J. Is photogrammetry of the face reliable? Plastic and reconstructive surgery 66, 346-355 (1980).

4 Diliberti, J. H. \& Olson, D. P. Photogrammetric evaluation in clinical genetics: theoretical considerations and experimental results. American journal of medical genetics 39, 161-166, doi:10.1002/ajmg.1320390209 (1991).

5 Han, K., Kwon, H. J., Choi, T. H., Kim, J. H. \& Son, D. Comparison of anthropometry with photogrammetry based on a standardized clinical photographic technique using a cephalostat and chair. J Craniomaxillofac Surg 38, 96-107, doi:10.1016/j.jcms.2009.04.003 (2010).

6 Tanner, J. M. Current advanced in the study of physique: Photogrammetric Anthropometry and an Androgyny scale. The Lancet 257, 574-579, doi:http://dx.doi.org/10.1016/S0140-6736(51)92260X (1951).

7 Saad, K. R., Colombo, A. S. \& João, S. M. A. Reliability and validity of the photogrammetry for scoliosis evaluation: a cross-sectional prospective study. J Manipulative Physiol Ther 32, 423-430, doi:10.1016/j.jmpt.2009.06.003 (2009).

8 Anic-Milosevic, S., Mestrovic, S., Prlić, A. \& Slaj, M. Proportions in the upper lip-lower lip-chin area of the lower face as determined by photogrammetric method. J Craniomaxillofac Surg 38, 90-95, doi:10.1016/j.jcms.2009.03.013 (2010).

9 Shaner, D. J., Bamforth, J. S., Peterson, A. E. \& Beattie, O. B. Technical note: Different techniques, different results--a comparison of photogrammetric and caliper-derived measurements. American journal of physical anthropology 106, 547-552, doi:10.1002/(sici)1096-8644(199808)106: 4<547::aid-ajpa9>3.0.co;2-f (1998).

10 Tanner, J. M. Normal growth and techniques of growth assessment. Clinics in endocrinology and metabolism 15, 411-451 (1986).

11 Kouchi, M., Mochimaru, M., Tsuzuki, K. \& Yokoi, T. Interobserver errors in anthropometry. Journal of human ergology 28, 15-24 (1999).

12 Ulijaszek, S. J. \& Kerr, D. A. Anthropometric measurement error and the assessment of nutritional status. Br J Nutr 82, 165-177 (1999). 



\section{Chapter 4|}

Estimation of body fat percentage in children and adolescents using photogrammetric anthropometry

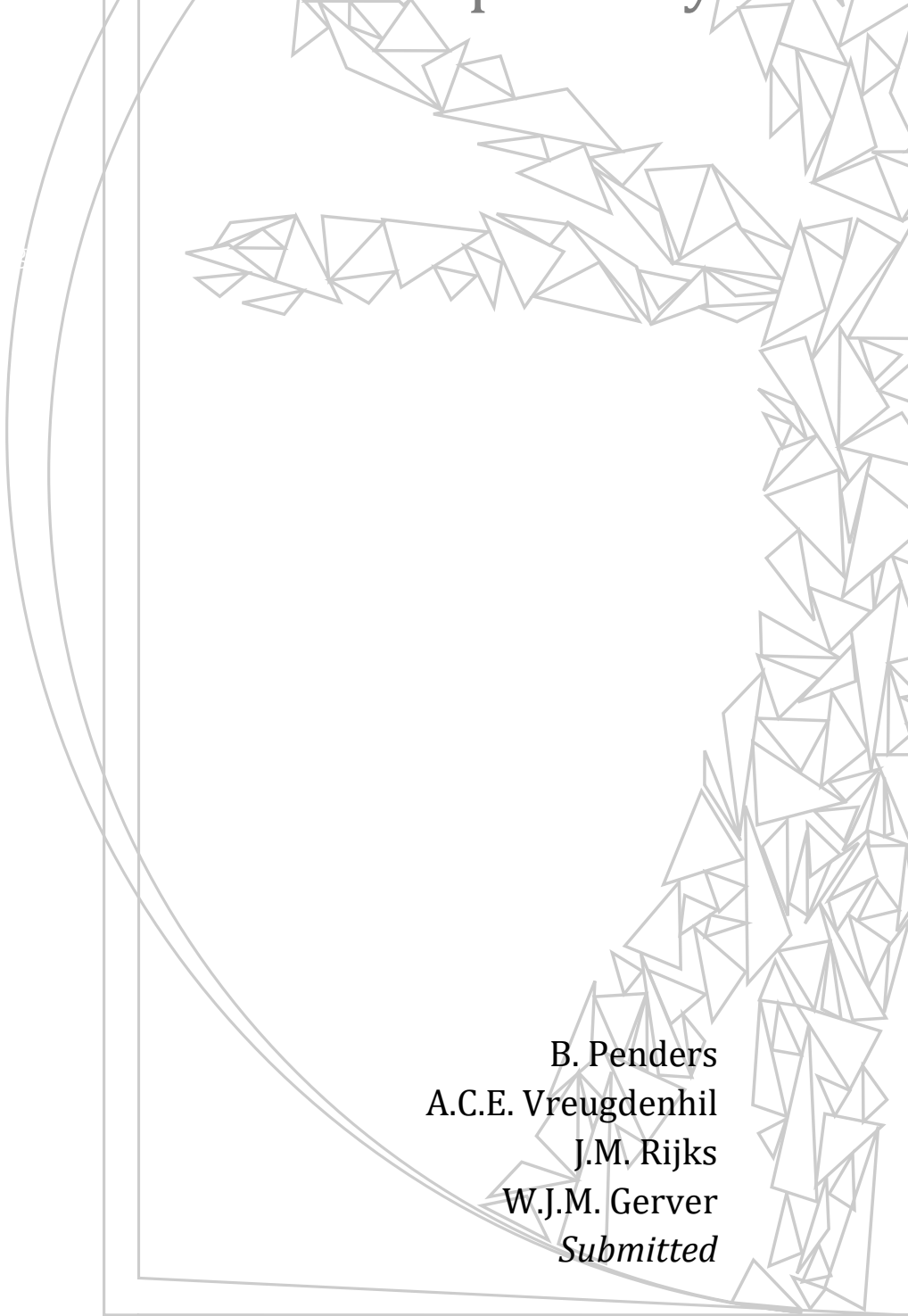




\section{Abstract}

\section{Background}

Body fat percentage is relevant in monitoring growth and health status in children, but difficult to measure outside research settings. Therefore, BMI and BMI z-score are used as alternative markers. When evaluating body fat percentage, it is vital that accurate and objective measurements of height and weight are performed. However, recurring visits to health professionals for measurements are cumbersome and home measurement is subjective and inaccurate.

\section{Methods}

This cross-sectional study performed in 133 children, 2-18 years old, aimed to investigate if body proportions, measured with photogrammetric anthropometry, can estimate body fat percentage. Subjects with a wide range of body weights varying from lean to morbidly obese were included.

\section{Results}

The ratio between biacromial width and waist width provides a similar strong relationship with body fat percentage $(r=-0.92)$ as BMI z-score $(r=-0.86)$. A linear regression model based on these body proportions provides an accurate estimate of body fat percentage in children, regardless of weight classification and independent of age and gender. A median difference in fat mass of 3.6\% IQR [1.5 - 5.9] $\left(r^{2}=0.85\right)$ was seen compared to measurements using deuterium dilution and airdisplacement plethysmography.

\section{Conclusion}

Photogrammetric anthropometry may provide an accurate, fast and easy to use alternative to BMI z-score in estimating body fat percentage in children based on body proportions. 


\section{What is known:}

- Monitoring growth of children is fundamental in the evaluation of development and health status.

- $\quad$ Body Mass Index (BMI) is used often as a practical alternative to estimate body fat percentage.

\section{What is new:}

- $\quad$ The ratio between the two-dimensional measurement of biacromial width and waist width can provide an accurate estimation of body fat percentage in children, regardless of weight classification and independent of age and gender.

- $\quad$ Photogrammetric anthropometry as a new method for measuring body proportions in children provides valuable assets over conventional methods. 


\section{Introduction}

Monitoring growth of children with anthropometric measurements is part of daily practice in paediatric healthcare. It is fundamental in the evaluation of development and health status.

Body fat percentage is directly related to health status and health risks of children ${ }^{1-4}$. It is of clinical importance across the whole range of body weight, including children suffering from underweight to morbid obesity. Direct measurement of body fat is feasible, using various techniques such as deuterium dilution, hydrostatic weighing or air-displacement plethysmography. Although these measurements are all suitable to measure body fat percentage, they are cumbersome, require expensive tools and are not easily applicable outside research settings. Therefore, practical alternative measurements have been sought to estimate body fat percentage, of which Body Mass Index (BMI) is used most often. It is defined as the ratio of body weight in kilograms to the square of height in meters.

Just as for other measurements, reference values of the BMI are given as a description of a certain population with its mean and standard deviation. Several studies have investigated the use of BMI as an alternative marker and confirmed a strong relationship between body fat percentage and BMI in children and adolescents ${ }^{5-7}$.

Despite the widespread use of BMI there are various circumstances in which the accuracy of the measurements is questionable, such as home measurement of body weight and height of children by parents, field studies in less developed countries, or in disabled children.

In this study, an alternative method of estimating body fat percentage is investigated. We made use of a new way of measuring various body proportions in children by means of photogrammetric anthropometry. Using digital photographs, a multitude of anthropometric measurements can be taken quickly, such as height, sitting height, arm span, biacromial width and biiliacal width. In a former study the accuracy of this method is presented ${ }^{8}$. It was shown to be a fast, easy to use, and validated method to take elaborate anthropometric measurements of the whole body, especially body proportions. One of the main assets of this method is that taking the photographs and performing the measurements is separated. This makes it a promising future method for home monitoring and large longitudinal measurement studies in which objective measurements can be collected and stored without the need for recurring outpatient visits.

In this study we investigated if body proportions measured in the two-dimensional photograph of a child are as accurate as the BMI in estimating body fat percentage, across a broad body weight distribution and wide age range. 


\section{Methods}

\section{Setting and design}

This cross-sectional study was conducted to investigate the relationship between body proportions and body fat percentage across a broad body weight range. Therefore, children varying from lean to morbidly obese were considered for inclusion according to the International Obesity Task Force (IOTF) criteria for $<18$ years old ${ }^{3}$. Lean children were included from the Paediatric Endocrinology outpatient clinic and children with overweight, obesity and morbid obesity were included from the Centre for Overweight Adolescent and Children's Healthcare ( $\mathrm{COACH}$ ), both at the Maastricht University Medical Centre (MUMC+).

This study was conducted according to the guidelines as stated by the Declaration of Helsinki and approved by the medical ethical committee of the MUMC+. Informed consent was subsequently obtained.

\section{Measurements}

Collected data used in this cross-sectional study was obtained by manual anthropometric measurements and by frontal digital photographs. Anthropometric measurements were taken of height, waist circumference, and hip circumference using a digital stadiometer and non-elastic measuring tape. All measurements were performed conform a standardised technique ${ }^{9}$. Digital photographs were made of the children in underwear conform the photogrammetric method described previously ${ }^{8}$. In summary, photographs were taken by the Medical Photography Unit of the academic hospital using a Canon EOS 70D digital camera and a lens with a set focal length of $50 \mathrm{~mm}$. Children were photographed in standard anatomical position against a fixed backboard and measurements were performed on these photographs using the photometry software Paediatric Morphometrics designed by our research group. The photometry method has previously shown to provide consistent results with inter-observer correlations of $\geq 0.96(\mathrm{p} \leq 0.001)^{8}$. 
Various anthropometric distances were determined on the photographs: height, biacromial width, waist width, hip width and trunk length (Figure 1). Waist width and hip width were defined as the greatest width in the frontal photograph at the level of the waist and hip respectively. Trunk length was determined as the distance from the sternal notch to the level of the waist width. BMI was calculated and BMI z-scores were obtained by means of the Dutch BMI for age reference curves obtained from the most current Dutch nationwide growth study ${ }^{10}$.

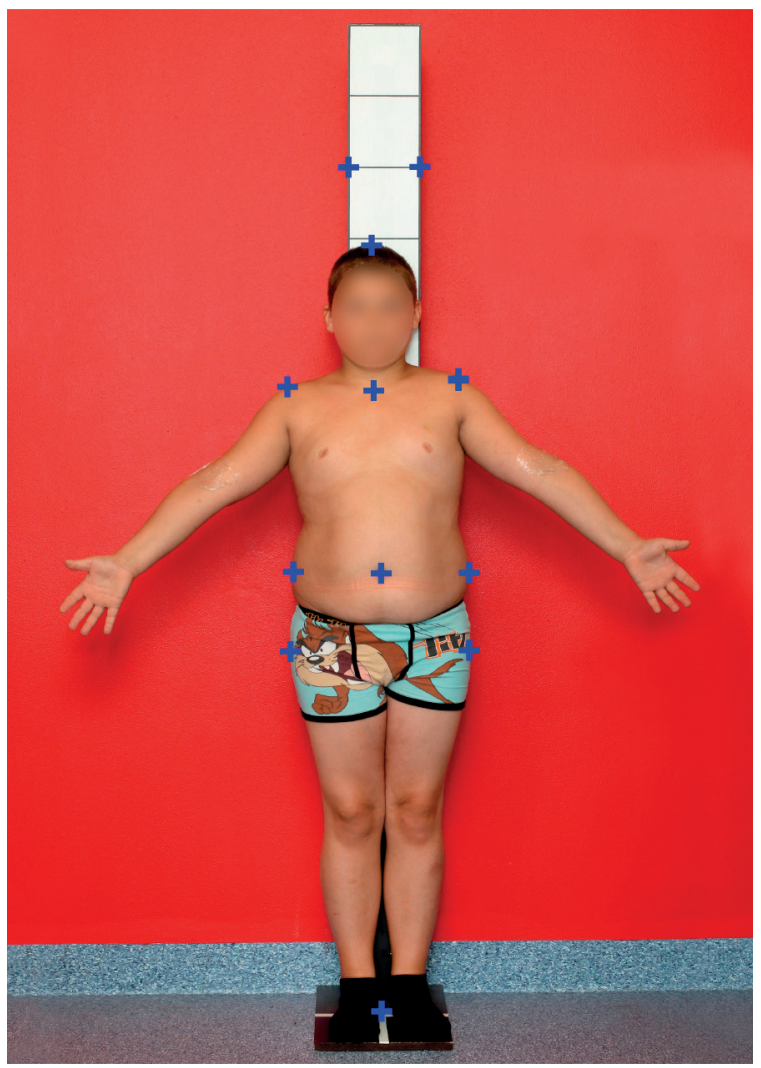

Fig. 1 | Photogrammetric measurements

Body fat percentage of lean children was determined by deuterium dilution according to the Maastricht Protocol ${ }^{11}$. A background urine sample was collected in the evening followed by consumption of approximately 75 millilitres of deuterium enriched water at night before bedtime, resulting in an enrichment of 100-150ppm. Deuterium dosage was $2.5 \mathrm{~g}<40 \mathrm{~kg}$ body mass and $3.5 \mathrm{~g}>40 \mathrm{~kg}$ body mass. After an overnight fast, the second voiding urine was collected next morning. To calculate fat free mass from total body water, age-dependent hydration factor calculations were performed ${ }^{12}$. 
For the children in the COACH program, body fat percentage was estimated using an air-displacement plethysmograph (BOD POD, Life Measurement Instruments, Concord, CA, USA) in accordance with the manufacturer's operating instructions. Detailed explanation of this measurement procedure has been described elsewhere ${ }^{13}$. All children wore tightly fitting bathing suits and a swim cap. A standard 2-point calibration process was performed using an empty chamber and a known volume of 50 litres. Two repeated measurements of body volume were performed and a mean value subsequently calculated. When the difference between the two measurements exceeded 150 millilitres, a third measurement was performed. The whole process was repeated if two values within 150 millilitres were not obtained. Raw body volume was corrected for thoracic gas volume and body surface area using formulae incorporated in the Bod Pod software. Fat mass percentage was then calculated using a 3-compartment model, as utilised by the Bod Pod software ${ }^{14}$.

Correlation analysis was performed between body fat percentage and anthropometric measurements. Various body proportions were incorporated into the analysis: biacromial width / waist width $($ Biac $/ W w)$, biacromial width / hip width $($ Biac $/ H w)$, waist width / height $(W w / H)$, hip width / height $(H w / H)$ and waist width / hip width $(\mathrm{Ww} / \mathrm{Hw})$. Since children with overweight and obesity have relatively more body fat stored in the trunk area compared to lean children, the area of the trunk (AoT) was determined using the following formula:

$$
\operatorname{AoT}\left(m^{2}\right)=\frac{1}{2} \cdot(\operatorname{biacromial} \text { width }(m)+\text { waist width }(m)) \cdot \operatorname{trunk} \operatorname{length}(m)
$$

\section{Statistical analysis}

All data were exported to IBM SPSS Statistics for Windows version 23.0 (SPSS Inc.) for statistical analysis. Shapiro-Wilk tests were performed for all measurements to test for normality. Correlations were determined in all weight categories with Pearson's correlation coefficient or Spearman's rho as appropriate.

Normal distributed data are presented as mean \pm SD, non-normal distributed data as median (min-max). A multivariate regression analysis was performed in both groups to investigate if determination of fat mass based on the aforementioned anthropometric measurements and ratios is possible. 


\section{Results}

\section{Characteristics of the study participants}

In total 133 children were enrolled in this study, 37 lean children, 38 children with overweight, 40 children with obesity and 18 children with morbid obesity. The patient characteristics of the study participants are presented in Table 1.

Table 1 | Characteristics of the study participants

\begin{tabular}{lllll}
\hline & Lean* & Overweight* & Obese* $^{*}$ & Morbidly obese* $^{*}$ \\
\hline $\mathrm{N}$ & 37 & 38 & 40 & 18 \\
Gender (male / female) & $28 / 9$ & $18 / 20$ & $19 / 21$ & $8 / 10$ \\
Age \pm SD & $10.9 \pm 3.0$ & $13.6 \pm 2.8$ & $13.2 \pm 3.0$ & $10.6 \pm 3.9$ \\
(range) & $(2.6-16.5)$ & $(8.1-17.9)$ & $(6.8-17.6)$ & $(3.6-17.8)$ \\
BMI z-score \pm SD & $-0.02 \pm 0.9$ & $2.3 \pm 0.3$ & $3.1 \pm 0.3$ & $3.9 \pm 0.4$ \\
Fat mass (\%) \pm SD & $16.6 \pm 7.2$ & $36.8 \pm 5.3$ & $42.9 \pm 4.9$ & $50.6 \pm 2.9$ \\
Waist circumference \pm SD & - & $82.48 \pm 8.8$ & $92.0 \pm 10.1$ & $96.3 \pm 15.0$ \\
Hip circumference \pm SD & - & $95.0 \pm 10.3$ & $104.4 \pm 12.9$ & $105.3 \pm 18.7$ \\
Waist width (range) (cm) & $22.2(18.9-32.2)$ & $33.8(27.8-40.6)$ & $38.0(27.6-43.9)$ & $37.5(22.5-48.2)$ \\
Hip width (range) $(\mathrm{cm})$ & $24.3(19.6-36.6)$ & $36.3(28.7-42.3)$ & $39.5(27.7-47.4)$ & $39.4(23.5-48.0)$ \\
AoT (range) (m2) & $0.08(0.06-0.16)$ & $0.13(0.08-0.19)$ & $0.14(0.08-0.18)$ & $0.13(0.05-0.22)$ \\
Biac/Ww \pm SD & $1.30 \pm 0.09$ & $1.00 \pm 0.08$ & $0.93 \pm 0.08$ & $0.90 \pm 0.08$ \\
Biac/Hw \pm SD & $1.20 \pm 0.07$ & $0.95 \pm 0.08$ & $0.90 \pm 0.08$ & $0.88 \pm 0.07$ \\
Ww/H (range) & $0.17(0.15-0.20)$ & $0.21(0.18-0.24)$ & $0.23(0.20-0.28)$ & $0.25(0.22-0.31)$ \\
Hw/H (range) & $0.18(0.17-0.21)$ & $0.22(0.19-0.27)$ & $0.24(0.21-0.28)$ & $0.25(0.22-0.29)$ \\
Ww/Hw (range) & $0.92(0.81-1.00)$ & $0.95(0.84-1.04)$ & $0.96(0.82-1.06)$ & $0.98(0.84-1.06)$ \\
\hline Data & & &
\end{tabular}

Data presented as mean \pm SD or as median (min-max). *According to the IOTF criteria.

Circumference measurements were not taken in lean children.

AoT, area of the trunk; Biac, biacromial width; BMI, Body Mass Index; H, height; Hw, hip width; Ww, waist width;

The correlations between the anthropometric measurements and fat mass percentage are presented in Table 2 for each IOTF group. Here, it is shown that waist width and hip width both provide a stronger correlation with fat mass percentage than waist circumference and hip circumference. 
Table 2 | Correlation analysis of anthropometric measurements and ratios

\begin{tabular}{lllllc}
\hline & \multicolumn{6}{l}{ FM(lean*) } & FM(overweight*) FM(obese*) & FM(morbidly obese*) & FM(all) \\
\hline Waist circumference & - & -0.20 & 0.11 & 0.29 & $0.32^{* *}$ \\
Hip circumference & - & $-0.39^{* *}$ & 0.11 & 0.32 & 0.19 \\
Waist width & 0.09 & -0.18 & 0.10 & 0.41 & $0.61^{* *}$ \\
Hip width & 0.06 & $-0.35^{* *}$ & -0.07 & 0.15 & $0.52^{* *}$ \\
AoT & -0.06 & $-0.42^{* *}$ & -0.13 & 0.26 & $0.31^{* *}$ \\
& & & & & $-0.92^{* *}$ \\
Biac/Ww & $-0.80^{* *}$ & $-0.60^{* *}$ & $-0.70^{* *}$ & $-0.72^{* *}$ & $-0.86^{* *}$ \\
Biac/Hw & $-0.61^{* *}$ & $-0.36^{* *}$ & $-0.52^{* *}$ & -0.34 & $0.84^{* *}$ \\
Ww/H & 0.28 & $0.48^{* *}$ & $0.39^{* *}$ & $0.70^{* *}$ & $0.72^{* *}$ \\
Hw/H & 0.12 & 0.14 & 0.11 & 0.16 & $0.49^{* *}$ \\
Ww/Hw & 0.36 & $0.49^{* *}$ & 0.30 & $0.54^{* *}$ & $0.77^{* *}$ \\
BMI & 0.16 & $-0.38^{* *}$ & 0.12 & 0.37 & $0.86^{* *}$ \\
BMI z-score & 0.14 & 0.06 & $0.33^{* *}$ & 0.14 & \\
*According to the IOTF criteria.**Correlations significant at (at least) the 0.05 level. \\
Circumference measurements were not taken in lean children. \\
AoT, area of the trunk; Biac, biacromial width; BMI, Body Mass Index; FM, fat mass; H, height; Hw, hip \\
width; Ww, waist width;
\end{tabular}

The correlation analysis for the anthropometric ratios is also presented in Table 2 . All anthropometric ratios correlated significantly with fat mass percentage when all groups are combined. When evaluating the separate IOTF groups, it is shown that solely the ratio between biacromial width and waist width $(B i a c / W w)$ provides consistent significant correlations with fat mass percentage across all IOTF groups. When all groups are combined, BMI z-score provides a similar correlation with fat mass, however this is not the case when the individual groups are considered.

\section{Body composition model}

A multivariate analysis was conducted to develop a linear regression model to determine fat mass percentage based on the aforementioned anthropometric measurements and ratios. Analysis showed that the ratio Biac $/ W w$ alone provided the most accurate determination of fat mass. This held true in each individual IOTF group. Thus leading to the following univariate regression model (Figure 2) with the formula:

$$
F M(\%)=105.83-67.61 \cdot\left(\frac{B i a c}{W w}\right) \quad\left(r^{2}=0.85\right)
$$




\section{Chapter 4}

Using this linear regression model, a median difference in fat mass of 3.6\% IQR [1.5 5.9], was seen compared to the measurements of fat mass percentage. This model did not change when controlling for age or gender and determines fat percentage with a standard error of the estimate of $4.8 \%$. Cross-validation provides an adjusted $r^{2}$ of 0.85 . Case wise diagnostics using Cook's distance and Mahalanobis distance revealed no cases with undue influence on the model. The assumptions concerning no multicollinearity, linearity, homoscedasticity and normal distribution of residuals were met. Residual plot analysis showed no bias across the range of fat mass percentage.

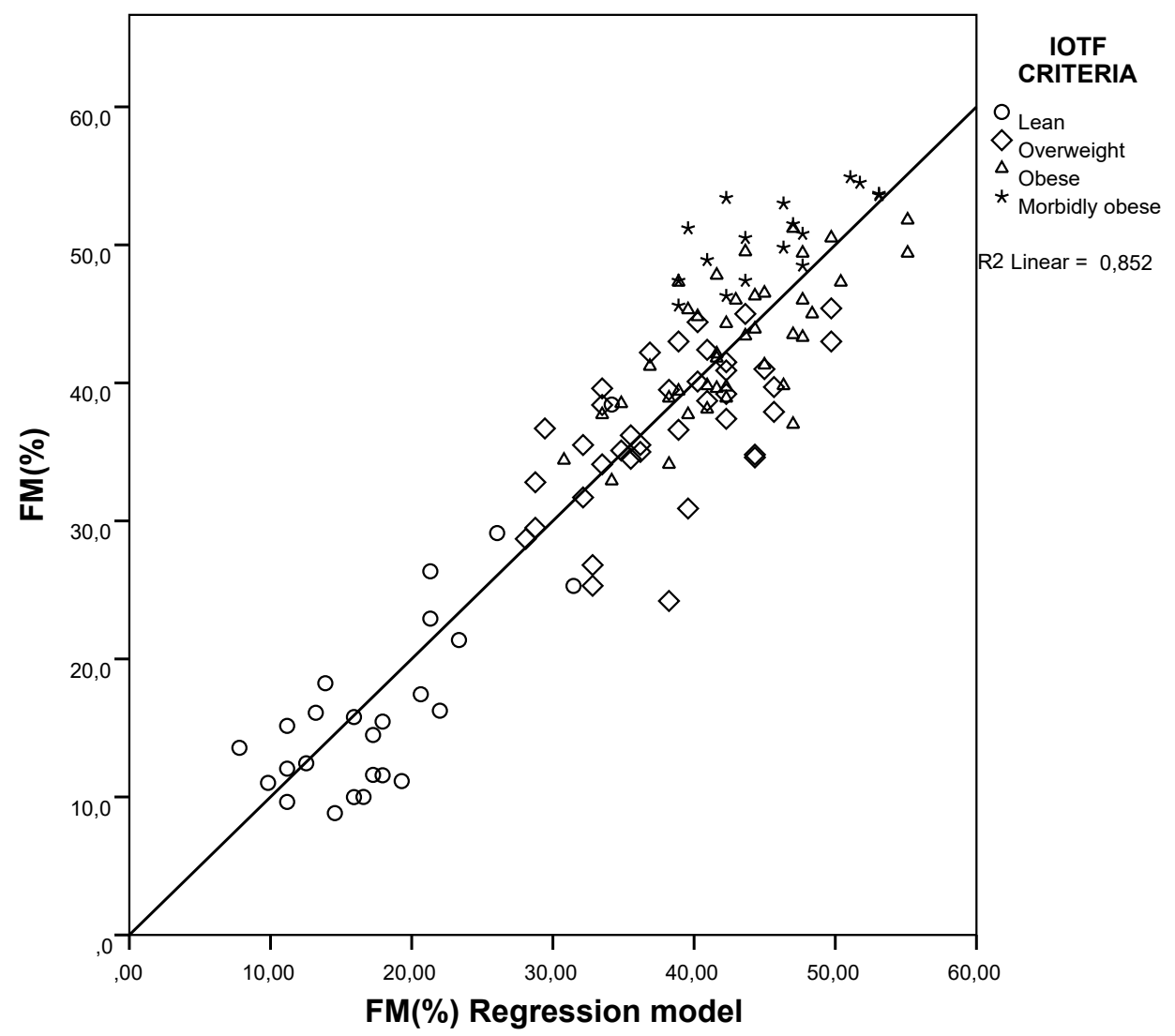

Fig. 2 | Correlation between fat mass (\%) and fat mass regression model (\%) 


\section{Discussion}

In this study it was shown that a linear regression model based on body proportions, measured using photogrammetric anthropometry, can accurately estimate fat mass percentage in children, regardless of IOTF classification and independent of age and gender. In this model, the ratio between biacromial width and waist width $($ Biac $/ W w)$ is used, which provided the strongest correlation with fat mass percentage.

To come to this model, the relationship between body fat percentage and various body proportions, including circumference measurements, width measurements and areal measurements, was evaluated. Since waist circumference and hip circumference are often used as anthropometric measurements to assess adiposity, especially intra-abdominal fat deposition, the use of waist and hip width measurements was considered as an alternative ${ }^{15-17}$. Interestingly, waist width and hip width showed an even stronger correlation with fat mass percentage than hip circumference and waist circumference (Table 2). Therefore, the data of this study show that waist width and hip width, determined using photogrammetric anthropometry, may be useful as a suitable alternative to the circumference measurements.

Apart from circumferential and width measurements, the relationship between areal measurement of the trunk and body fat mass percentage was evaluated. The area of the Trunk (AoT) was found to correlate significantly with fat mass percentage in obese children only. Interestingly, the ratio between the measurements of biacromial width and waist width incorporated into this area provides a stronger correlation with fat mass percentage across all IOTF groups. This gives rise to the hypothesis that the ratio between shoulders and waist, irrespective of the trunk length gives a more representative reflection of body fat percentage.

The study population consisted of two groups in which different methods for the estimation of body fat percentage are used, deuterium dilution and air-displacement plethysmography. These methods are both proven to be valid and accurate in determining body fat percentage in children and were previously described to have excellent correlations 18-20. Due to these two methods, both groups were evaluated separately and separate multivariate regression analyses were performed. However, since separate models did not differ significantly from each other, the combined model as shown was conducted. As seen in the scatterplot of the multivariate model, both techniques show strong correlations and a good alignment (Figure 2).

Because of its simplicity and ease of use, it is understandable that BMI is an attractive alternative to measurement of body fat percentage for many paediatricians and health care providers $3,4,21,22$. What makes the photometry 


\section{Chapter 4}

method so attractive, is the separation between taking the photographs and performing the measurements. This means that objective measurements can be performed by the paediatrician, who does not need to be present when the photographs are taken. This can eliminate the need of recurring outpatient visits, solely for measurements, which can be cumbersome for parents and a psychological burden on children, especially in monitoring of overweight and obesity. This makes it a promising method for home monitoring and also large longitudinal measurement studies. Here, photogrammetric anthropometry can prove itself very useful in the measurement of challenging patient groups, such as in children with disabilities or those with difficulty in maintaining a certain pose for accurate manual measurement. Also, as many measurements can be leisurely performed on the photographs as wanted. Since it is also possible to store the original photograph, measurements can always be reviewed and additional measurements can be performed in a later stadium, without further burdening the child.

Future studies will focus on the practical implementation of the photometry method. Potentially through development of mobile application software so that this method may be easily used in the field and in home monitoring.

\section{Conclusion}

This study shows that measurement of body proportions, which can be done in a fast, easy to use and accurate way using photogrammetric anthropometry, provides a reliable estimation of body fat percentage in children, across a wide age range and a broad body weight spectrum.

\section{Acknowledgements}

We thank all children and their parents for their cooperation. Special thanks go to Angèle Gerver for her management of the deuterium dilution procedures and Engelbert Schins and Ed Smeets of the Medical Photography Unit for their aid in data collection.

\section{Disclosure Statement}

The authors have no conflicts of interest to disclose.

\section{Author Contributions}

B.P., A.C.E.V. and W.J.M.G. were responsible for the study design. B.P. performed the data analysis and drafts of the paper. All authors contributed to writing and revising the manuscript and approved the final draft. 


\section{References}

1 Gishti, 0. et al. Body fat distribution, metabolic and inflammatory markers and retinal microvasculature in school-age children. The Generation R Study. International journal of obesity 39, 1482-1487, doi:10.1038/ijo.2015.99 (2015).

2 Zhu, S., Wang, Z., Shen, W., Heymsfield, S. B. \& Heshka, S. Percentage body fat ranges associated with metabolic syndrome risk: results based on the third National Health and Nutrition Examination Survey (1988-1994). Am J Clin Nutr 78, 228-235 (2003).

3 Cole, T. J. \& Lobstein, T. Extended international (IOTF) body mass index cut-offs for thinness, overweight and obesity. Pediatr Obes 7, 284-294, doi:10.1111/j.2047-6310.2012.00064.x (2012).

4 Neovius, M., Linné, Y., Barkeling, B. \& Rössner, S. Discrepancies between classification systems of childhood obesity. Obes Rev 5, 105-114, doi:10.1111/j.1467-789X.2004.00136.x (2004).

5 Pietrobelli, A. et al. Body mass index as a measure of adiposity among children and adolescents: a validation study. The Journal of pediatrics 132, 204-210 (1998).

6 Goulding, A. et al. DEXA supports the use of BMI as a measure of fatness in young girls. International journal of obesity and related metabolic disorders : journal of the International Association for the Study of Obesity 20,1014-1021 (1996).

7 Lindsay, R. S. et al. Body mass index as a measure of adiposity in children and adolescents: relationship to adiposity by dual energy x-ray absorptiometry and to cardiovascular risk factors. $J$ Clin Endocrinol Metab 86, 4061-4067, doi:10.1210/jcem.86.9.7760 (2001).

8 Penders, B., Brecheisen, R., Gerver, A., van Zonneveld, G. \& Gerver, W. J. Validating Paediatric Morphometrics: body proportion measurement using photogrammetric anthropometry. Journal of pediatric endocrinology \& metabolism : JPEM 28, 1357-1362, doi:10.1515/jpem-2015-0172 (2015).

9 Gerver, W. J. M. \& de Bruin, R. Paediatric Morphometrics: A Reference Manual. 3 edn, (Universitaire Pers Maastricht, 2011).

10 Schonbeck, Y. et al. Increase in prevalence of overweight in Dutch children and adolescents: a comparison of nationwide growth studies in 1980, 1997 and 2009. PloS one 6, e27608, doi:10.1371/journal.pone.0027608 (2011).

11 Westerterp, K. R., Wouters, L. \& van Marken Lichtenbelt, W. D. The Maastricht protocol for the measurement of body composition and energy expenditure with labeled water. Obes Res 3 Suppl 1, 49-57 (1995).

12 Lohman, T. G. Assessment of Body Composition in Children. Pediatric Exercise Science 1, 19-30 (1989).

13 Dempster, P. \& Aitkens, S. A new air displacement method for the determination of human body composition. Medicine and science in sports and exercise 27, 1692-1697 (1995).

14 Siri, W. E. Body composition from fluid spaces and density: analysis of methods. 1961. Nutrition (Burbank, Los Angeles County, Calif.) 9, 480-491; discussion 480, 492 (1993).

15 Brannsether, B., Eide, G. E., Roelants, M., Bjerknes, R. \& Júlíusson, P. B. Interrelationships between anthropometric variables and overweight in childhood and adolescence. Am J Hum Biol 26, 502-510, doi:10.1002/ajhb.22554 (2014).

16 Blüher, S. et al. Body mass index, waist circumference, and waist-to-height ratio as predictors of cardiometabolic risk in childhood obesity depending on pubertal development. J Clin Endocrinol Metab 98, 3384-3393, doi:10.1210/jc.2013-1389 (2013).

17 Hirschler, V., Ruiz, A., Romero, T., Dalamon, R. \& Molinari, C. Comparison of different anthropometric indices for identifying insulin resistance in schoolchildren. Diabetes Technol Ther 11, 615-621, doi:10.1089/dia.2009.0026 (2009).

18 Fields, D. A. \& Allison, D. B. Air-displacement plethysmography pediatric option in 2-6 years old using the four-compartment model as a criterion method. Obesity (Silver Spring) 20, 1732-1737, doi:10.1038/oby.2012.28 (2012).

19 Ma, G. et al. Validation of a new pediatric air-displacement plethysmograph for assessing body composition in infants. Am J Clin Nutr 79, 653-660 (2004). 


\section{Chapter 4}

20 Collins, A. L. \& McCarthy, H. D. Evaluation of factors determining the precision of body composition measurements by air displacement plethysmography. European journal of clinical nutrition 57,770 776, doi:10.1038/sj.ejcn.1601609 (2003).

21 Demerath, E. W. et al. Do changes in body mass index percentile reflect changes in body composition in children? Data from the Fels Longitudinal Study. Pediatrics 117, e487-495, doi:10.1542/peds.2005-0572 (2006).

22 Maynard, L. M. et al. Childhood body composition in relation to body mass index. Pediatrics 107, 344350 (2001). 




\section{Chapter 5}

\section{Body Proportions in Children with}

Kabuki Syndrome

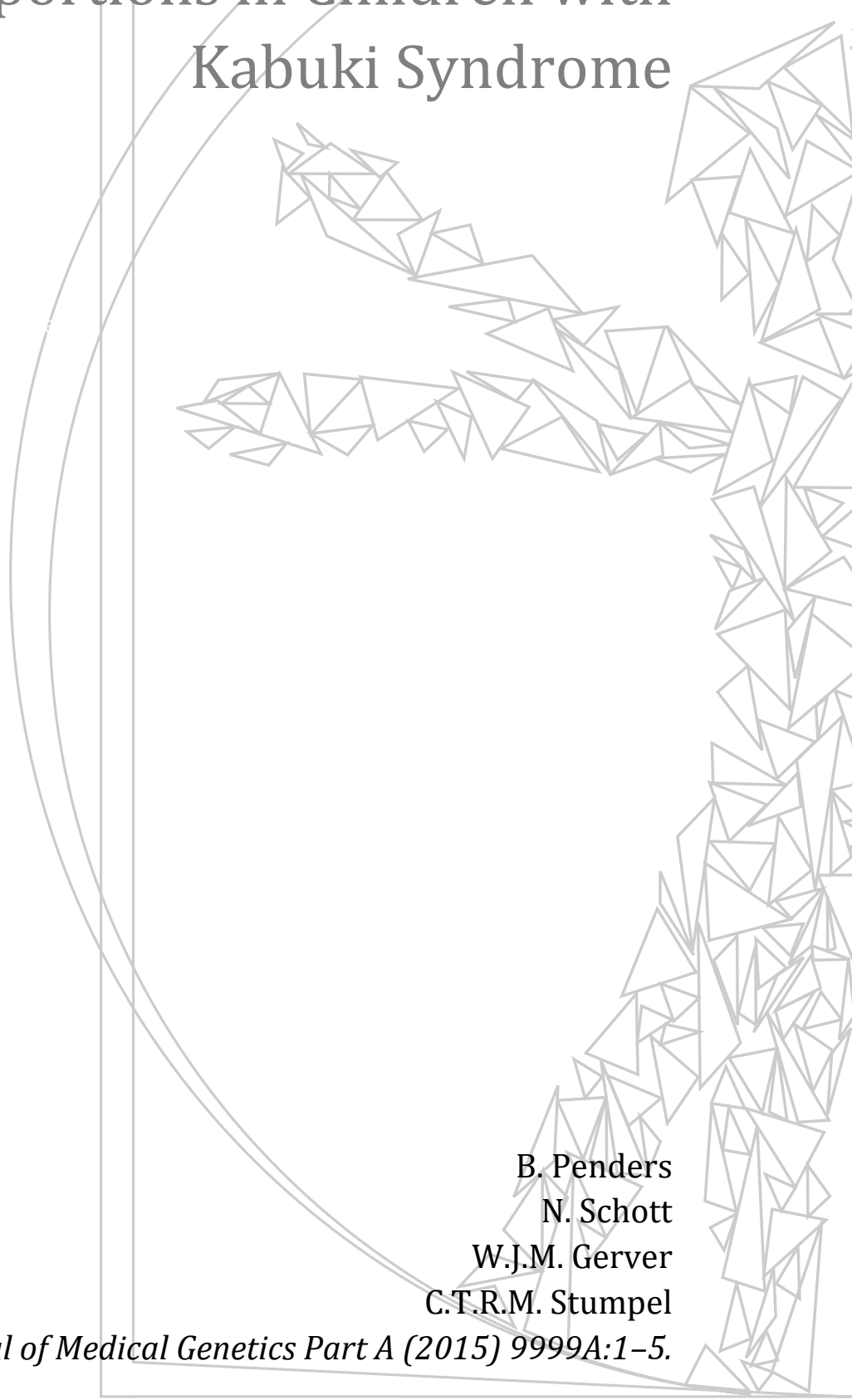

American Journal of Medical Genetics Part A (2015) 9999A:1-5. 


\section{Abstract}

\section{Background}

Typical facial characteristics, short stature, and skeletal anomalies have been described for the clinical diagnosis of Kabuki Syndrome (KS) in children. However, no studies have investigated body proportions in KS. Knowledge of body proportions in KS may contribute to better insight into the growth pattern and characterisation of this genetic disorder. Therefore, we compared body proportions of children with KS to normally proportioned controls to investigate if atypical body proportions are part of this genetic disorder.

\section{Methods}

This study was designed and conducted within the setting of the Maastricht University Medical Centre (MUMC+), the official Dutch expert centre for Kabuki syndrome. We conducted a cross-sectional study in 32 children (11 children with KS and 21 controls). Body proportions were determined by means of photogrammetric anthropometry, measurements based on digital photography.

\section{Results}

Body proportions, quantified as body ratios, differ significantly in children with KS from normally proportioned children. Children with KS have smaller heads and longer arms proportional to their trunks and have been found to have longer upper arms proportional to their tibia length and feet.

\section{Conclusion}

Based on deviations in body proportions it was shown possible to discern children with KS from normally proportioned controls. 


\section{Introduction}

Children with Kabuki syndrome (KS) are characterised by a distinct facial appearance, mild to moderate mental retardation, postnatal growth retardation, skeletal anomalies and unusual dermatoglyphic patterns ${ }^{1}$. Two genes have shown to be mutated in patients with $\mathrm{KS}, 55-80 \%$ present mutations in the MLL2/KMT2D gene and in $9-14 \%$ the KDM6A gene is mutated ${ }^{2-4}$.

The facial characteristics, which are used in the clinical diagnosis of KS, have been described extensively in recent literature, several studies also describe the presence of short stature and skeletal anomalies in $\mathrm{KS}^{1,5-9}$. However, no studies have investigated body proportions in these children. Knowledge of body proportions in KS may contribute to better insight into the growth pattern and characterisation of this genetic disorder. Therefore, we performed a cross-sectional study to compare body proportions of children with KS to normally proportioned controls.

\section{Methods}

This study was designed and conducted within the setting of the Maastricht University Medical Centre (MUMC+), the official Dutch expert centre for Kabuki syndrome. Work is performed in close collaboration with the Dutch Kabuki Network.

\section{Study groups}

In total, 11 children, between 3 and 16 years old, visiting the expert centre for Kabuki syndrome in the Maastricht University Medical Centre were included in this study. KS was confirmed in all participating children based on the presence of gene mutations in MLL2. No mutations in KDM6A were found.

For the control group, 21 children between 2 and 14 years old, visiting the outpatient clinic of Endocrinology and Growth of the Maastricht University Medical Centre were included. These children were all proportioned normally according to the Dutch reference values ${ }^{10}$. Before inclusion, all patients and/or their parents had given informed consent.

\section{Measurements}

In a previous study we developed a new method for taking anthropometric measurements, using photogrammetric anthropometry. It was shown to be a fast, easy to use, validated method to take elaborate anthropometric measurements of the whole body, especially body proportions ${ }^{11}$. Collected data used in this crosssectional study are digital photographs taken of the children in underwear. Photographs are taken in a frontal and lateral position and measurements on these 


\section{Chapter 5}

photographs are performed using the photometry software Paediatric Morphometrics designed by our research group. Digital photographs were taken conform the photogrammetric method described previously ${ }^{11}$. Body proportions were determined according to the measurements of various anthropometric distances by selecting anatomical reference points in the photographs. These are the same reference points used in manual measurements ${ }^{10}$. The measurements included: height $(H)$, head length $(H I)$, biacromial width (Biac), biiliacal width $($ Biil), upper arm length $(U A)$, lower arm length $(L A)$, hand length $(H A)$, tibia length (Tibl) and foot length $(F O)$. Additionally, trunk length $(\operatorname{Tr} l)$ was determined on the photograph as the height difference between biacromial width and biiliacal width. Arm length $(A R M)$ was determined as the summation of upper arm length, lower arm length and hand length.

\section{Statistical analysis}

All data was exported to IBM SPSS Statistics for Windows version 20.0 for statistical analysis. Shapiro-Wilk tests were performed for all measurements to test for normality. Comparison of different groups was done using independent student T-test, Mann Whitney U test or Fisher's exact as appropriate. 


\section{Results}

\section{Characteristics of the study participants}

A total of 32 children were enrolled in this study (11 children with KS and 21 controls). Both groups were comparable regarding age and gender. Significant differences between groups were seen in several proportional measurements. All characteristics are presented in Table 1.

Table 1 | Characteristics of the study participants

\begin{tabular}{llll}
\hline & Children with KS & Controls & p-value \\
\hline $\mathrm{N}$ & 11 & 21 & 0.433 \\
Gender m / f \%) & $58 / 42$ & $76 / 24$ & 0.138 \\
Age & $8.3 \pm 3.4$ & $10.2 \pm 3.3$ & \\
(range) & $(3.7-16.0]$ & $(2.6-14.8)$ & $<0.001$ \\
Hl/H & $0.20 \pm 0.03$ & $0.17 \pm 0.02$ & $<0.001$ \\
Hl/Trl & $0.82 \pm 0.07$ & $0.55 \pm 0.06$ & 0.363 \\
Biac/Biil & $1.25 \pm 0.12$ & $1.22 \pm 0.07$ & 0.457 \\
Biac/H & $0.22[0.20-0.23]$ & $0.23[0.22-0.23]$ & 0.123 \\
Biil/H & $0.17[0.16-0.20]$ & $0.18[0.18-0.19]$ & $<0.001$ \\
Trl/H & $0.25[0.23-0.26]$ & $0.30[0.29-0.32]$ & 0.289 \\
ARM/H & $0.43[0.38-0.45]$ & $0.42[0.41-0.43]$ & $<0.001$ \\
ARM/Trl & $1.76[1.68-1.88]$ & $1.35[1.31-1.47]$ & 0.565 \\
UA/LA & $1.24 \pm 0.16$ & $1.21 \pm 0.07$ & $<0.001$ \\
UA/Tibl & $0.97 \pm 0.06$ & $0.76 \pm 0.05$ & $<0.001$ \\
UA/FO & $1.30 \pm 0.09$ & $1.09 \pm 0.09$ & $<0.001$ \\
Tibl/H & $0.19 \pm 0.02$ & $0.23 \pm 0.01$ & 0.051 \\
Tibl/Trl & $0.80[0.77-0.84]$ & $0.77[0.70-0.79]$ & 0.027 \\
FO/Tibl & $0.75 \pm 0.07$ & $0.70 \pm 0.05$ & \\
\hline Data & & & \\
\hline
\end{tabular}

Data presented as mean \pm SD or as median [IQR]

$\mathrm{H}$, height; Hl, head length; Biac, biacromial width; Biil, biiliacal width; Trl, trunk length; UA, upper arm length; LA, lower arm length; HA, hand length; ARM, arm length; Tibl, tibia length; FO, foot length

The eight ratios $H l / H, T r l / H, H l / T r l, A R M / T r l, U A / T i b l, U A / F O, T i b l / H$ and FO/Tibl show significant differences between children with KS and normally proportioned children. When presented for age, the ratios $\mathrm{Hl} / \mathrm{Trl}, \mathrm{ARM} / \mathrm{Trl}, U A / \mathrm{Tibl}$ and $U A / F O$ show distinct distribution differences. These distributions are presented in Graph 1-4, where the black dots represent the control group and the white dots represent the KS group. 

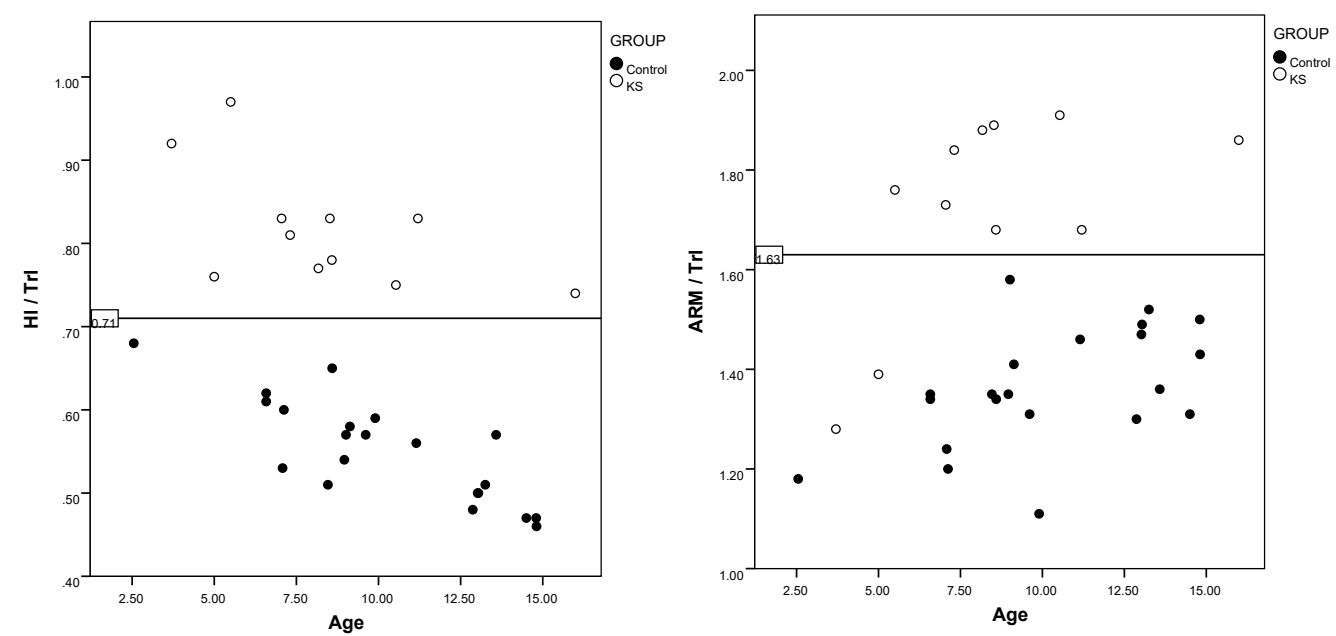

Graph 1 | Hl/Trl distribution for age;

$\mathrm{Hl}$, head length; Trl, trunk length

Graph 2 | ARM/Trl distribution for age;

ARM, arm length; Trl, trunk length
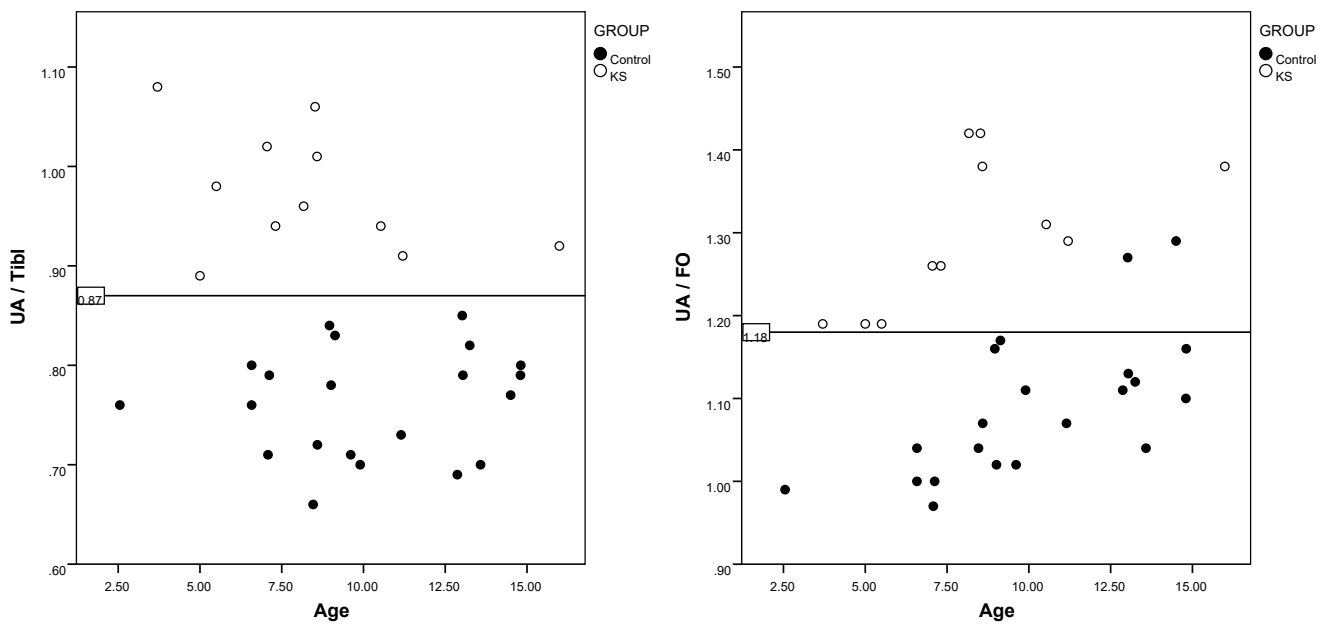

Graph 3 | UA/Tibl distribution for age; UA, upper arm; Tibl, tibia length

Graph 4 | UA/FO distribution for age; UA, upper arm; FO, foot

\section{Discussion}

To our best knowledge, this is the first report on body proportions in children with Kabuki syndrome. We used photogrammetric anthropometry to estimate the body proportions of these children and compared the results to a reference group of normally proportioned children. We also used this method to determine if atypical body proportions are a characteristic feature in children with KS. 
The ratios $H I / T r l, A R M / T r l, U A / T i b l$, and $U A / F O$ for age in children with KS clearly differentiate from the reference group. These ratios show that children with KS have smaller heads and longer arms proportional to their trunks compared to normally proportioned children. Additionally, children with KS have been found to have longer upper arms proportional to their tibia length and feet. These differences can be quantified as proportional cut-off values which are independent of age. In all children with KS a Hl/Trl ratio $>0.71$ was found, opposed to the reference group which showed a $H I / T r l$ ratio $<0.71$. Similar results were found for $A R M / \operatorname{Trl}(>1.63$ for KS), $U A /$ Tibl $(>0.87$ for $\mathrm{KS}$ ) and $U A / F O(>1.18$ for $\mathrm{KS})$. Based on these deviations in body proportions it was shown possible to discern children with KS from normally proportioned controls. Analysis of these body proportions can be done accurately with photogrammetric anthropometry, which is a fast, low-cost and easy to perform method.

In other conditions where short stature and skeletal anomalies are present, such as idiopathic short stature (ISS), SHOX gene (short stature homeobox-containing gene) defects and Turner syndrome (TS), more research has been done on body proportions. In an extensive study of Malaquias et al., abnormal body proportions were observed in $88 \%$ of the children with SHOX-defects, $48 \%$ of the females with TS and $16 \%$ of children considered to have ISS ${ }^{12}$. However, only sitting height / height ratio $(\mathrm{SH} / \mathrm{H})$ was investigated. In our study, it was not possible to accurately determine sitting height, neither manually, nor with the aid of photogrammetric anthropometry. Since children with KS often have difficulty with maintaining a certain pose for accurate manual measurement, sitting height was proven to be inaccurate. In a previous study we investigated if sitting height could be determined on a photograph, however this lead to imperfect results ${ }^{11}$. However, with the aid of photogrammetric anthropometry, we were able to examine other anthropometric ratios, that gave us an elaborate overview of the body proportions of these children. It is known that in many skeletal dysplasias, growth of the legs and arms is often more negatively affected than growth of the trunk ${ }^{13}$. Interestingly, we found that in children with KS arm length was proportionately longer compared to trunk length. No significant differences were found between groups for tibia length proportional to trunk length.

When SHOX gene defects are present, shortening of the extremities is a main cause of short stature. In these children, the arm span and leg length is significantly reduced in comparison to the height ${ }^{14,15}$. In children with KS we found no significant differences in arm length proportional to height compared to normally proportioned children, although tibia length was significantly shorter proportional to their height.

Body proportions in TS have between described in untreated girls between 2-11 years of age. Since height is more affected in these children than other parts of the body, these girls have, on average, a relatively large trunk, large hands and feet, and 


\section{Chapter 5}

relatively large biacromial width and biiliacal width proportional to their height 16 . In the children with KS we found that they had, on average, a relatively small trunk compared to normally proportioned controls. Also, we found no significant differences in biacromial width and biiliacal width proportional to height between the children with KS and the reference group.

Apart from $\mathrm{SH} / \mathrm{H}$ ratio, body proportions have not been elaborately described in children with idiopathic short stature. Therefore, comparison of body proportions to the children with $\mathrm{KS}$ in this study is not yet possible.

In future studies we will compare body proportions in KS with other conditions in which short stature and skeletal anomalies are present. It will be interesting to determine if the proportional ratios presented in this study can also be used to differentiate various skeletal anomalies in children from each other.

\section{Conclusion}

To our best knowledge, this is the first report on body proportions in Kabuki syndrome. It is shown here that various body ratios in KS clearly deviate from normally proportioned children. The key differences in body proportions in KS are that these children have smaller heads and longer arms proportional to their trunks and longer upper arms proportional to their tibia length and feet. Knowledge of these body proportions in KS is valuable, since it can strengthen the clinical diagnosis and provide the means to follow up on the body proportions during growth and development.

\section{Acknowledgements}

The authors thank the children with Kabuki syndrome, their families, and the Dutch Kabuki Network for their collaboration. The authors have no conflicts of interest to disclose. 


\section{References}

1 Niikawa, N., Matsuura, N., Fukushima, Y., Ohsawa, T. \& Kajii, T. Kabuki make-up syndrome: a syndrome of mental retardation, unusual facies, large and protruding ears, and postnatal growth deficiency. The Journal of pediatrics 99, 565-569 (1981).

$2 \mathrm{Ng}$, S. B. et al. Exome sequencing identifies MLL2 mutations as a cause of Kabuki syndrome. Nature genetics 42, 790-793, doi:10.1038/ng.646 (2010).

3 Lederer, D. et al. Deletion of KDM6A, a histone demethylase interacting with MLL2, in three patients with Kabuki syndrome. American journal of human genetics 90, 119-124, doi:10.1016/j.ajhg.2011.11.021 (2012).

4 Dentici, M. L. et al. Kabuki syndrome: clinical and molecular diagnosis in the first year of life. Archives of disease in childhood 100, 158-164, doi:10.1136/archdischild-2013-305858 (2015).

5 Schrander-Stumpel, C. T., Spruyt, L., Curfs, L. M., Defloor, T. \& Schrander, J. J. Kabuki syndrome: Clinical data in 20 patients, literature review, and further guidelines for preventive management. American journal of medical genetics. Part A 132A, 234-243, doi:10.1002/ajmg.a.30331 (2005).

6 Wilson, G. N. Thirteen cases of Niikawa-Kuroki syndrome: report and review with emphasis on medical complications and preventive management. American journal of medical genetics 79, 112120 (1998).

7 Mhanni, A. A., Cross, H. G. \& Chudley, A. E. Kabuki syndrome: description of dental findings in 8 patients. Clinical genetics 56, 154-157 (1999).

8 Digilio, M. C., Marino, B., Toscano, A., Giannotti, A. \& Dallapiccola, B. Congenital heart defects in Kabuki syndrome. American journal of medical genetics 100, 269-274 (2001).

9 Shotelersuk, V., Punyashthiti, R., Srivuthana, S. \& Wacharasindhu, S. Kabuki syndrome: report of six Thai children and further phenotypic and genetic delineation. American journal of medical genetics 110, 384-390, doi:10.1002/ajmg.10474 (2002).

10 Gerver, W. J. M. \& de Bruin, R. Paediatric Morphometrics: A Reference Manual. 3 edn, (Universitaire Pers Maastricht, 2011).

11 Penders, B., Brecheisen, R., Gerver, A., van Zonneveld, G. \& Gerver, W.-J. Validating Paediatric Morphometrics: body proportion measurement using photogrammetric anthropometry. Journal of pediatric endocrinology \& metabolism : JPEM, doi:10.1515/jpem-2015-0172 (2015).

12 Malaquias, A. C. et al. The sitting height/height ratio for age in healthy and short individuals and its potential role in selecting short children for SHOX analysis. Hormone research in paediatrics 80, 449-456, doi:10.1159/000355411 (2013)

13 Hagenäs, L. \& Hertel, T. Skeletal dysplasia, growth hormone treatment and body proportion: comparison with other syndromic and non-syndromic short children. Hormone research $60 \mathrm{Suppl}$ 3, 65-70, doi:74504 (2003).

14 Ross, J. L. et al. Phenotypes Associated with SHOX Deficiency. J Clin Endocrinol Metab 86, 5674-5680, doi:10.1210/jcem.86.12.8125 (2001).

15 Binder, G., Ranke, M. B. \& Martin, D. D. Auxology is a valuable instrument for the clinical diagnosis of SHOX haploinsufficiency in school-age children with unexplained short stature. J Clin Endocrinol Metab 88, 4891-4896, doi:10.1210/jc.2003-030136 (2003).

16 Sas, T. C. et al. Body proportions during long-term growth hormone treatment in girls with Turner syndrome participating in a randomized dose-response trial. J Clin Endocrinol Metab 84, 4622-4628, doi:10.1210/jcem.84.12.6225 (1999). 



\section{Chapter 6}

An analysis of body proportions in children with CHARGE syndrome using photogrammetric anthropometry

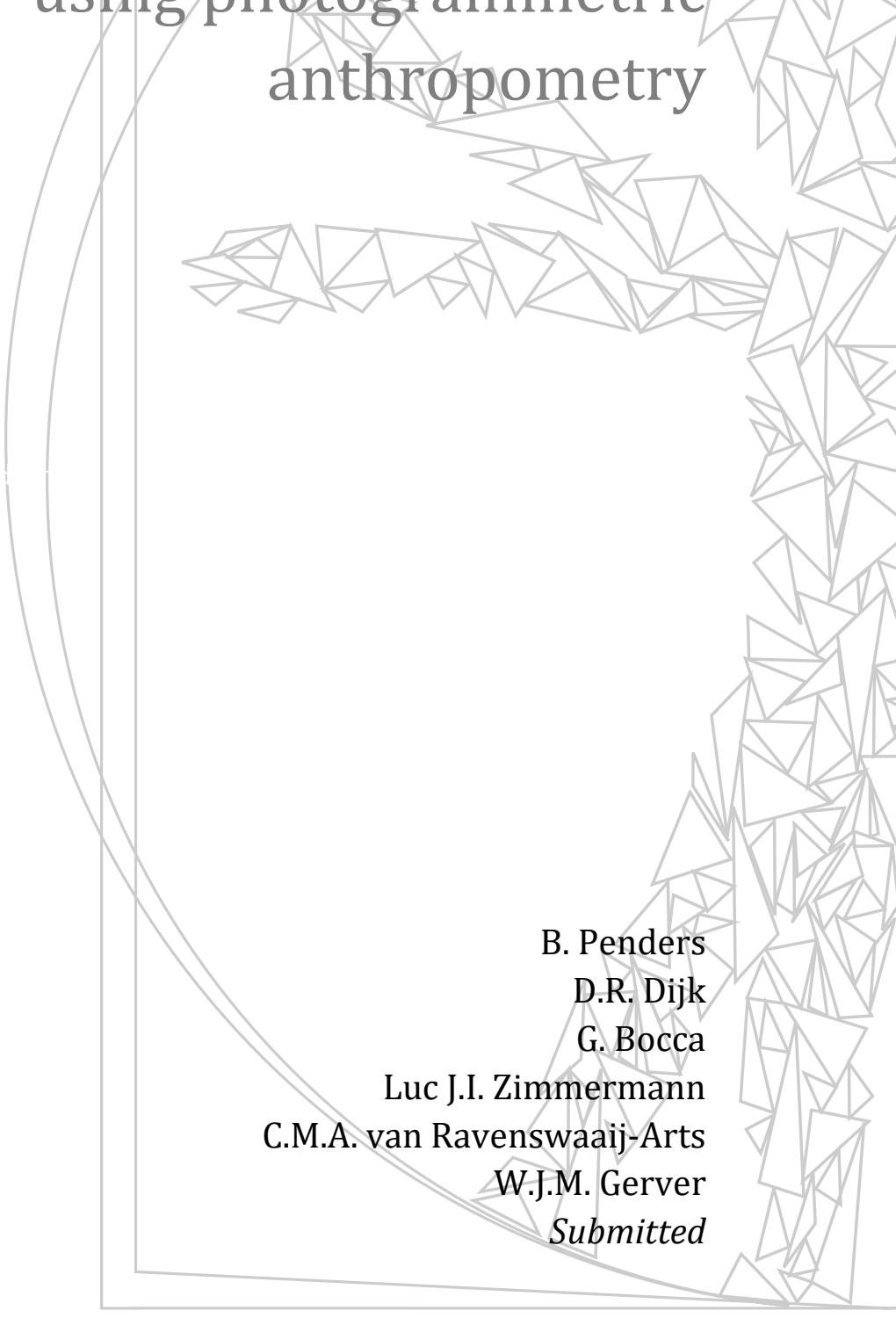




\section{Abstract}

\section{Background}

Although growth retardation is one of the main hallmarks of CHARGE syndrome (CS), little is known about normal and abnormal growth in these children, especially on body proportions. Knowledge of body proportions in CS may contribute to better insight into the growth pattern and characterisation of this disorder.

\section{Methods}

This cross-sectional study was designed and conducted in close collaboration between the Maastricht University Medical Centre (MUMC+) and the Dutch expert centre for CHARGE syndrome of the University Medical Centre Groningen (UMCG). A cross-sectional study was conducted in 53 children (32 children with CS and 21 controls). Photogrammetric anthropometry, a measurement method based on digital photographs, was used to determine various body proportions.

\section{Results}

Significant differences in body proportions were observed in children with CS opposed to normally proportioned controls. Children with CS appear to have a shorter trunk in proportion to their height, head length and arm length. Also, smaller feet proportional to tibia length were noted. The change of body proportions with increasing age was shown to be similar in children with CS and controls.

\section{Conclusion:}

Body proportions in children with CS are significantly different from normally proportioned controls, with similar change of body proportions with increasing age. 


\section{Introduction}

CHARGE syndrome (CS) is a rare disorder, characterised by multiple anomalies, including coloboma of the eye, heart defects, atresia of the choanae, retardation of growth and/or development, genital hypoplasia, and ear and hearing abnormalities. The occurrence and extent of these anomalies can be different among patients. The diagnostic criteria for CS were introduced by Blake and Verloes, using these and other frequent characteristics of CS, such as aplasia of semicircular canals and cranial nerve dysfunction ${ }^{1-3}$. In 2004, mutations in the CHD7 gene were identified to be responsible for the CHARGE phenotype ${ }^{4}$. Since then, many different mutations scattered around the CHD7 gene have been found, and are detected in over $75 \%$ of patients with $\mathrm{CS}^{5}$. The reported incidence of CS varies widely. In a Dutch cohort the incidence was estimated to be $1 / 15.000$ to $1 / 17.000$ live births ${ }^{6}$.

Although growth retardation is one of the main characteristics of CS, little is known about the specific growth pattern in these children. Typically, children with CS have normal or slightly decreased birth weight and length. Within the first three months after birth, growth rate decreases and patients with CS already show significantly lower weight and height compared to a reference population ${ }^{7,8}$. During the following years of life, some catch-up growth occurs, but height remains significantly below average in both boys and girls ${ }^{7-9}$. The exact cause of this growth retardation remains unclear, several factors that might contribute to growth retardation have been suggested, including feeding difficulties, cardiac malformations and endocrinological problems such as growth hormone deficiency and hypothyroidism. Of these factors, cardiac malformations and feeding difficulties are highly prevalent in $\mathrm{CS}^{10-12}$. Growth hormone deficiency and hypothyroidism is found in a minority of patients ${ }^{13-15}$. In addition to reduced prepubertal growth, $75 \%$ of girls and $82 \%$ of boys with CS have gonadotrophin deficiency and do not achieve spontaneous puberty. Therefore, they lack a pubertal growth spurt, unless treated with sex hormones ${ }^{16,17}$. Despite these observations, the growth pattern and proportional development of children with CS remains largely unknown.

In conclusion, although growth retardation is one of the main characteristics of CS, little is known about the growth pattern in these children. Therefore, this crosssectional study was performed to assess body proportions in children with CS and compare these to normally proportioned controls. 


\section{Methods}

This cross-sectional study was designed and conducted in close collaboration between the Maastricht University Medical Centre (MUMC+) and the official Dutch expert centre for CHARGE syndrome of the University Medical Centre Groningen (UMCG).

\section{Study groups}

In total, 32 children with CS between 2 and 18 years old were included in this study. Inclusion was performed in children visiting the Dutch CHARGE Family Day in 2016 or 2017, an annual event organised by the UMCG to provide parents of children with CS the opportunity to share experiences and convey to them new developments in research. Also, children with CS visiting the $13^{\text {th }}$ International CHARGE Syndrome Conference, in Orlando, Florida, U.S., were considered for inclusion. Only children with a proven mutation of the CHD7 gene were eligible for inclusion in this study. For the control group, 21 children between 2 and 14 years old, visiting the outpatient clinic of Endocrinology and Growth of the Maastricht University Medical Centre were included. These children were all proportioned normally according to the most recent Dutch reference values ${ }^{18}$. Before inclusion, all patients and/or their parents had given written informed consent. In accordance with Dutch law, this study did not need to be approved by an institutional review board.

\section{Measurements}

Digital photographs were taken of the children in underwear in frontal and lateral position conform the photogrammetric method described previously ${ }^{19}$. The children in the reference group were photographed at the Maastricht University outpatient clinic in standard anatomical position against a fixed backboard. The children with CS were photographed at the locations of the CHARGE Family Day and the conference according to standard protocol. For most children with CS it is challenging to stand unaided in a standard anatomical position. Therefore, relatives accompanying the children were coached into aiding with the positioning process. Multiple photographs were taken to ensure that the various anthropometric measurements could be performed as best as possible. A reference measure of known size was used to compare the various measurements across photographs. Body proportions were calculated from anthropometric measurements by selecting the anatomical reference points on these photographs using the photometry software Paediatric Morphometrics designed by our research group. This photometry technique is more patient-friendly than taking elaborate manual measurements in children who are difficult to instruct and measure and was previously shown to provide consistent results with inter-observer correlations $\geq 0.96(\mathrm{p} \leq 0.001)^{19}$. 
Various anthropometric measurements were determined on the photographs: height $(H)$, head length $(H I)$, biacromial width (Biac), biiliacal width (Biil), upper arm length (UA), lower arm length (LA), hand length (HA), tibia length (Tibl) and foot length ( $F O$ ). These measurements were taken conform a standardised technique ${ }^{18,20}$. Additionally, trunk length (Trl) was determined on the photograph as the height difference between biacromial width and biiliacal width. Arm length (ARM) was determined as the summation of upper arm length, lower arm length and hand length.

\section{Statistical analysis}

All data were exported to IBM SPSS Statistics for Windows version 23.0 for statistical analysis. Shapiro-Wilk tests were performed for all measurements to test for normality. Comparison of different groups was done using independent samples T-test, Mann-Whitney U test or Chi-Square test as appropriate.

\section{Results}

\section{Characteristics of the study participants}

A total of 53 children were enrolled in this study (32 children with CS and 21 controls). There was a significant difference in gender distribution between the two groups, with no significant variation in age. All characteristics are presented in Table 1.

Several body ratios showed significant differences between the CS group and the control group. These are: head length / height, head length / trunk length, trunk length / height, arm length / height, arm length / trunk length, upper arm length / tibia length, tibia length / height, and foot length / tibia length. Additionally, T-tests were performed to investigate if these body ratios were influenced by gender, which showed no significant differences (data not shown). 
Table 1 | Characteristics of the study participants

\begin{tabular}{|c|c|c|c|}
\hline & Children with CS & Controls & p-value \\
\hline $\mathrm{N}$ & 32 & 21 & \\
\hline Gender (male / female) & $11 / 21$ & $16 / 5$ & $0.003^{*}$ \\
\hline Age \pm SD & $8.0 \pm 4.67$ & $10.2 \pm 3.3$ & 0.069 \\
\hline (range) & $(2.6-18.7)$ & $(2.6-14.8)$ & \\
\hline $\mathrm{Hl} / \mathrm{H}$ & $0.18 \pm 0.02$ & $0.17 \pm 0.02$ & $0.050^{*}$ \\
\hline $\mathrm{Hl} / \mathrm{Trl}$ & $0.67 \pm 0.07$ & $0.55 \pm 0.06$ & $<0.001^{*}$ \\
\hline Biac/Biil & $1.18 \pm 0.12$ & $1.22 \pm 0.07$ & 0.230 \\
\hline $\mathrm{Biac} / \mathrm{H}$ & $0.22(0.17-0.28)$ & $0.23(0.21-0.23)$ & 0.537 \\
\hline Biil/H & $0.19(0.15-0.22)$ & $0.18(0.17-0.20)$ & 0.541 \\
\hline $\mathrm{Trl} / \mathrm{H}$ & $0.27 \pm 0.02$ & $0.30 \pm 0.02$ & $<0.001^{*}$ \\
\hline $\mathrm{ARM} / \mathrm{H}$ & $0.40(0.35-0.45)$ & $0.43(0.39-0.45)$ & $0.012^{*}$ \\
\hline ARM/Trl & $1.51 \pm 0.15$ & $1.37 \pm 0.11$ & $<0.001^{*}$ \\
\hline UA/LA & $1.25 \pm 0.20$ & $1.21 \pm 0.07$ & 0.340 \\
\hline UA/Tibl & $0.85 \pm 0.10$ & $0.76 \pm 0.05$ & $<0.001^{*}$ \\
\hline Tibl/H & $0.21(0.17-0.23)$ & $0.22(0.20-0.25)$ & $<0.001^{*}$ \\
\hline Tibl/Trl & $0.76 \pm 0.10$ & $0.75 \pm 0.06$ & 0.787 \\
\hline Fo/Tibl & $0.67 \pm 0.06$ & $0.70 \pm 0.05$ & $0.047^{*}$ \\
\hline
\end{tabular}

Data presented as mean \pm SD or as median (min-max); *significance $\leq 0.05 ; \mathrm{H}$, height; Hl, head length; Biac, biacromial width; Biil, biiliacal width; Trl, trunk length; UA, upper arm length; LA, lower arm length; HA, hand length; ARM, arm length; Tibl, tibia length; FO, foot length

Body proportions were analysed in relation to age and several body ratios showed an evident distinction in distribution. These distributions are presented in Graph 1-8. The black dots represent the control group and the white dots represent the CS group.

In graphs 1-2, it is shown that children with CS have a similar change in body proportions regarding the ratio between head length and both height and trunk length as normally proportioned controls. With advancing age, total height and trunk become proportionally larger to the head. The distribution pattern is similar; however, the proportional ratios are not. On average, children with CS are shown to have a shorter trunk, proportional to their head length than the children in the control group. The relative shorter trunk is also observed when seen proportional to height, as shown in graph 3. As opposed to the $\mathrm{Hl} / \mathrm{Tr}$ ratio, the $\mathrm{Trl} / \mathrm{H}$ ratio does not show a clear correlation with age, both in children with CS and in the control group. 


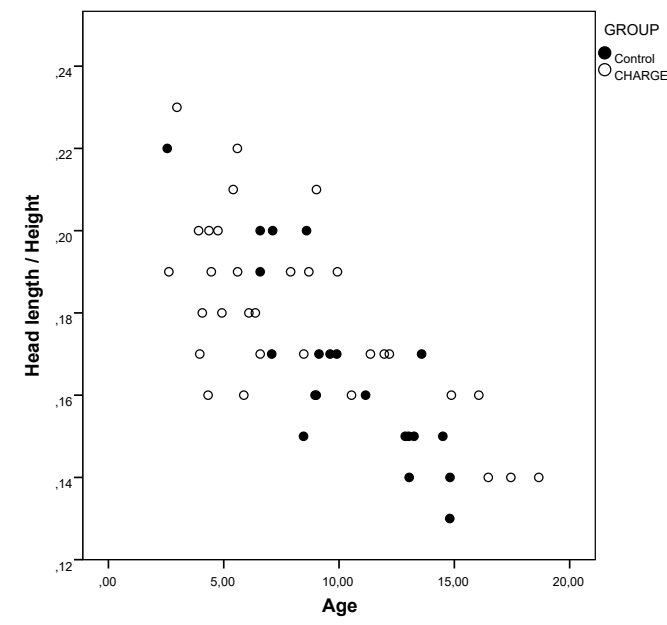

Graph 1 | Hl/H distribution for age

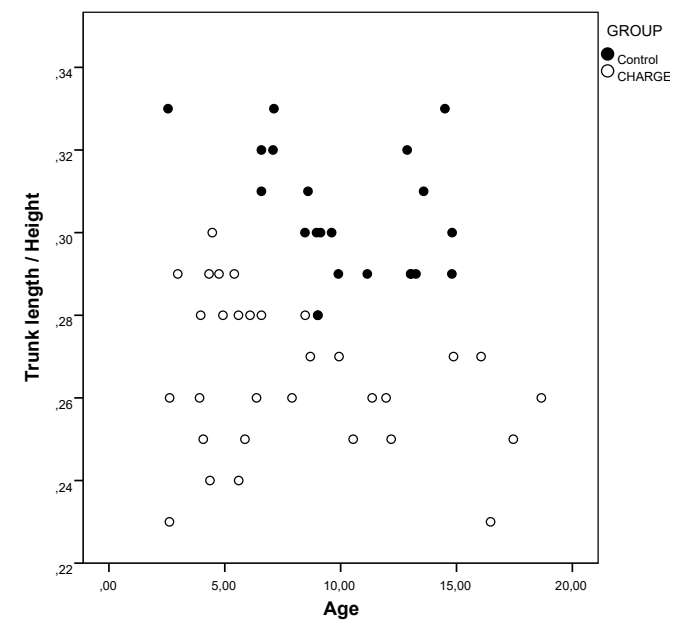

Graph 3 | Trl/H distribution for age

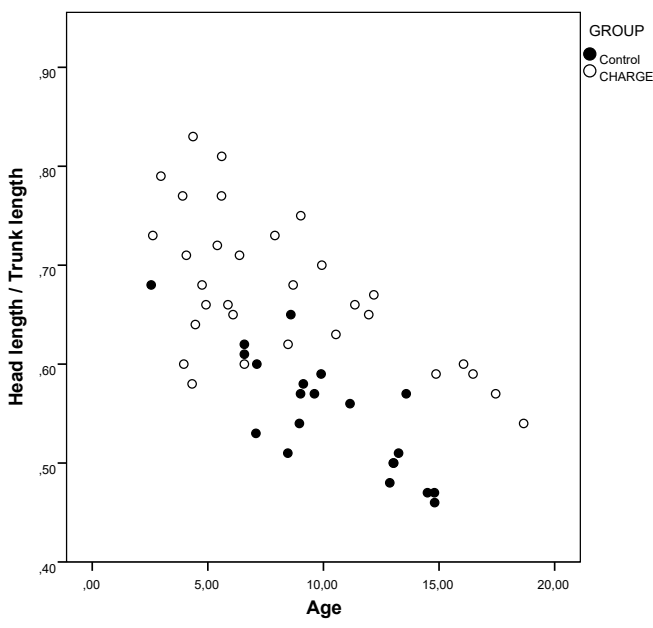

Graph 2 | Hl/Trl distribution for age

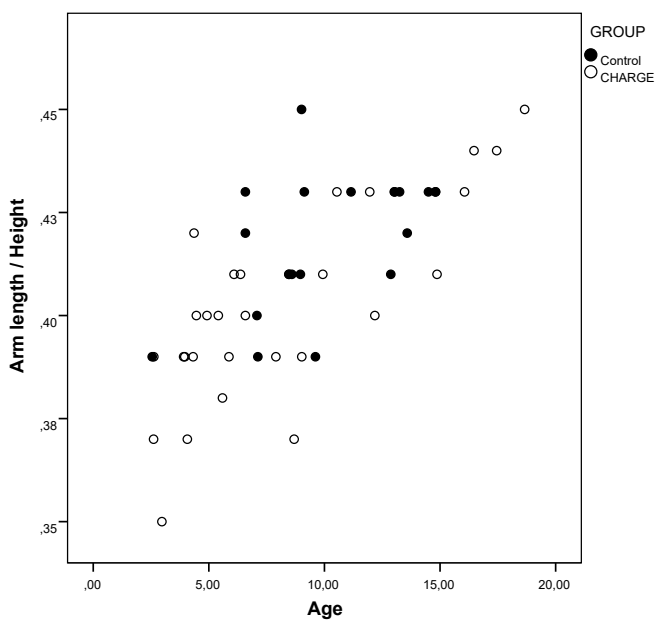

Graph 4 | ARM/H distribution for age

Graphs 4-5 show that in children with CS the change of proportions of the arm length to both height and trunk length with age is similar to controls, however the children with CS appear to have on average longer arms in relation to their trunks. Graph 6 presents the relationship between upper arm length and tibia length, which does not show a clear distribution difference between children with CS and controls. Tibia length to height is presented in graph 7, which shows that in predominantly younger children the tibia length appears to be shorter, relative to total height. In older children, this difference becomes less pronounced. Lastly, graph 8 reflects the relationship between foot length and tibia length, here the distribution across age is 


\section{Chapter 6}

similar for both groups. However, it is shown that children with CS have, on average, smaller feet proportional to their tibia length opposed to controls.
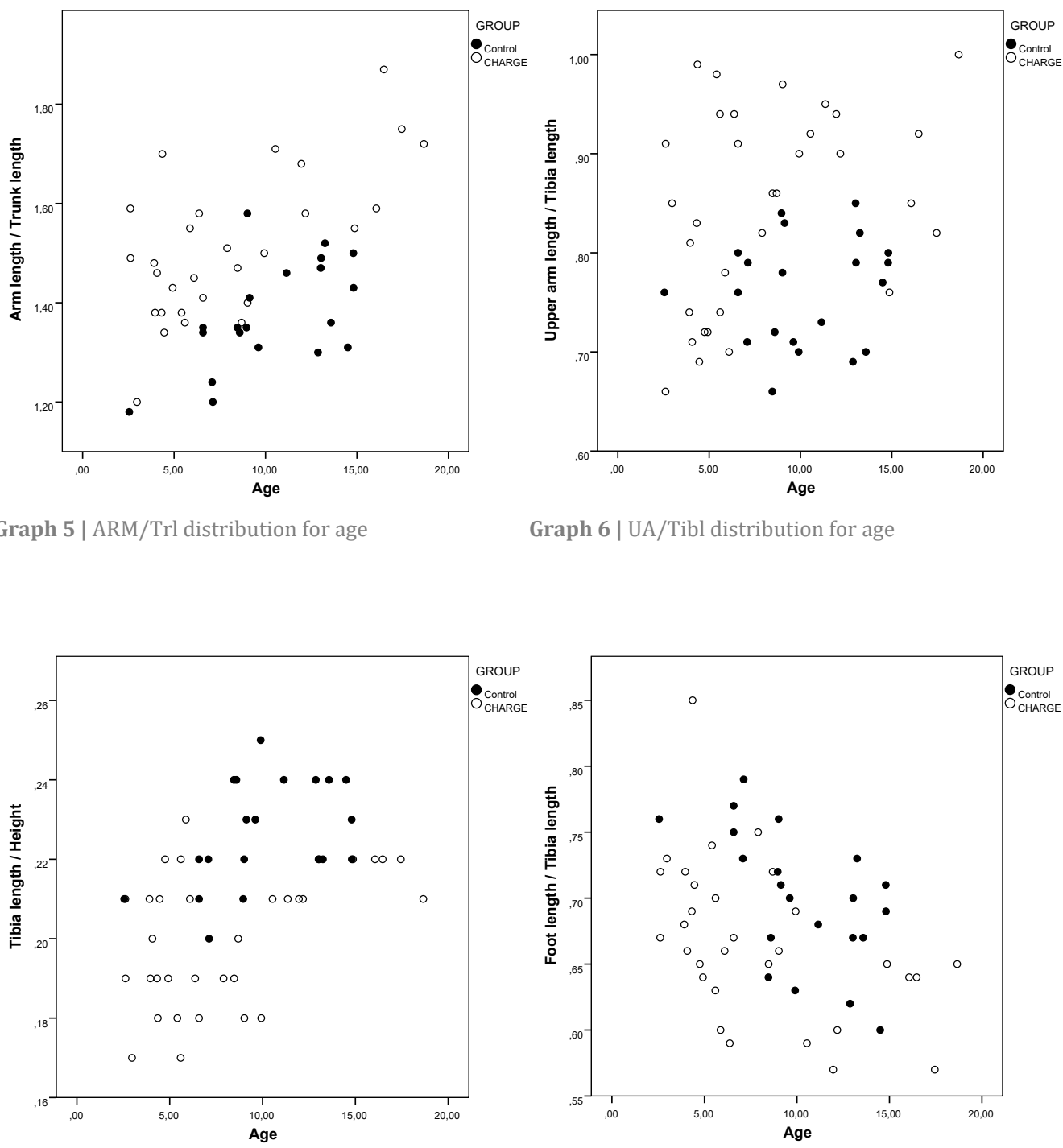

Graph 7 | Tibl/H distribution for age

Graph 8 | FO/Tibl distribution for age 


\section{Discussion}

\section{Overview}

This study was conducted to gain more information about the body proportions in children with CS and to assess if abnormal body proportions are part of this syndrome. Apart from growth retardation in general, this is the first study that investigates the possible proportional anomalies in CS. As can be seen in graphs 18 , some proportional ratios are shown to be different in children with CS compared to the normally proportioned controls. It is important to note that the relationship of the various body proportions to age appears to be similar in children with CS and normally proportioned controls. Therefore, we may conclude that the growth process of the body goes through the same proportional changes. The most important difference found in this study between children with CS and controls is that children with CS appear to have a relative shorter trunk. This has been observed for trunk length in proportion to height, head length and arm length. Of these body proportions, the relationship between trunk length and height does not show a clear correlation with age. This can be explained by the fact that the trunk length and height share a linear relationship. The total height increases at the same speed as the trunk length, which results in the proportional ratio staying the same ${ }^{18}$.

Interestingly, the results of this study show some similarities as were found in children with Kabuki Syndrome (KS). In both syndromes, children appear to have shorter trunks, proportional to their arm length ${ }^{21}$. Previous studies have hinted at a possible association and clinical overlap between CHARGE syndrome and Kabuki Syndrome 22,23 . The clinical features shared between both syndromes include congenital heart defects, growth and/or developmental retardation and urogenital malformations. The results of this study broaden this overlap with proportional distinction from normally proportioned controls.

\section{Strengths}

Photogrammetric anthropometry allows for fast accumulation of data for measurement of body proportions. The strength of this method, opposed to classic anthropometry, is that several photographs can be combined to perform the measurements and not one ideal pose has to be found. This allows for a less invasive measurement technique which proves to be more patient-friendly than taking elaborate manual measurements and is also less frustrating for the observers. Additionally, the original data of the patient is preserved in the digital photograph, which makes retroactive measurement possible, without needing to trouble the patient once more. In future longitudinal studies, this new technique will provide unique comparability potential in de monitoring of growth and development of individual patients, which is lost when simply comparing measurement values. 


\section{Chapter 6}

\section{Weaknesses and considerations for future studies}

In the present study, the distribution in gender is not the same across the observed groups. The CHARGE group consist of relatively more girls and the control group has more boys. To see if this difference would provide an undue representation of body ratios, T-tests were performed, which showed no significant differences based on gender. Since most included children of both groups are prepubertal and due to a small study population, no subdivision was made according to pubertal stages. In this study population a similar change in body proportions across age and gender was observed in both groups, which might be explained by the fact that most of the children were prepubertal. Since gonadotropin deficiency is relatively common in children with CS and spontaneous puberty may not be achieved, which may well be reflected in different development of body proportions. In future studies, especially when the growth and developmental process of patients with CHARGE syndrome is followed longitudinally, it will be interesting to investigate the influence of delayed puberty or impact and timing of puberty induction on body proportions.

\section{Conclusion}

Children with CHARGE syndrome appear to have a shorter trunk in proportion to their height, head length and arms. Also, this study shows that children with CS have, on average, smaller feet proportional to their tibia length opposed to controls. No clear differences in change of body proportions with age are observed between children with CS and controls.

\section{Acknowledgements}

The authors thank all the children with CS and their families for their collaboration.

\section{Disclosure Statement}

The authors have no conflicts of interest to disclose. 


\section{References}

1 Hsu, P. et al. CHARGE syndrome: a review. Journal of paediatrics and child health 50, 504-511, doi:10.1111/jpc.12497 (2014).

2 Blake, K. D. et al. CHARGE association: an update and review for the primary pediatrician. Clinical pediatrics 37, 159-173 (1998).

3 Verloes, A. Updated diagnostic criteria for CHARGE syndrome: a proposal. American journal of medical genetics. Part A 133A, 306-308, doi:10.1002/ajmg.a.30559 (2005).

4 Vissers, L. E. et al. Mutations in a new member of the chromodomain gene family cause CHARGE syndrome. Nature genetics 36, 955-957, doi:10.1038/ng1407 (2004).

5 Blake, K. D. \& Prasad, C. CHARGE syndrome. Orphanet journal of rare diseases,1750-1172-1-34 (2006).

6 Janssen, N. et al. Mutation update on the CHD7 gene involved in CHARGE syndrome. Human mutation 33, 1149-1160, doi:10.1002/humu.22086 (2012).

7 Blake, K., Kirk, J. M. \& Ur, E. Growth in CHARGE association. Arch. of dis. in childhood 68, 508-509 (1993).

8 Legendre, M. et al. Antenatal spectrum of CHARGE syndrome in 40 fetuses with CHD7 mutations. Journal of Medical Genetics 49, 698-707, doi:10.1136/jmedgenet-2012-100926 (2012).

9 Dorr, H. G., Madeja, J. \& Junghans, C. Spontaneous postnatal growth is reduced in children with CHARGE syndrome. Acta Paediatr 104, e314-318, doi:10.1111/apa.12980 (2015).

10 Dobbelsteyn, C., Peacocke, S. D., Blake, K., Crist, W. \& Rashid, M. Feeding difficulties in children with CHARGE syndrome: prevalence, risk factors, and prognosis. Dysphagia 23, 127-135, (2008).

11 Blake, K. D. \& Hudson, A. S. Gastrointestinal and feeding difficulties in CHARGE syndrome: A review from head-to-toe. American journal of medical genetics. Part C, Seminars in medical genetics 175, 496-506, doi:10.1002/ajmg.c.31586 (2017).

12 Corsten-Janssen, N. et al. The cardiac phenotype in patients with a CHD7 mutation. Circulation. Cardiovascular genetics 6, 248-254, doi:10.1161/circgenetics.113.000054 (2013).

13 Shoji, Y. et al. Endocrinological Characteristics of 25 Japanese Patients with CHARGE Syndrome. Clinical pediatric endocrinology : case reports and clinical investigations : official journal of the Japanese Society for Pediatric Endocrinology 23, 45-51, doi:10.1297/cpe.23.45 (2014).

14 Pinto, G. et al. CHARGE syndrome includes hypogonadotropic hypogonadism and abnormal olfactory bulb development. J Clin Endocrinol Metab 90, 5621-5626, doi:10.1210/jc.2004-2474 (2005).

15 Asakura, Y. et al. Endocrine and radiological studies in patients with molecularly confirmed CHARGE syndrome. J Clin Endocrinol Metab 93, 920-924, doi:10.1210/jc.2007-1419 (2008).

16 Bergman, J. E., Bocca, G., Hoefsloot, L. H., Meiners, L. C. \& van Ravenswaaij-Arts, C. M. Anosmia predicts hypogonadotropic hypogonadism in CHARGE syndrome. The Journal of pediatrics 158, 474-479, (2011).

17 Balasubramanian, R. \& Crowley, W. F., Jr. Reproductive endocrine phenotypes relating to CHD7 mutations in humans. American journal of medical genetics. Part C, Seminars in medical genetics 175, 507-515, doi:10.1002/ajmg.c.31585 (2017).

18 Gerver, W. J. M. \& de Bruin, R. Paediatric Morphometrics: A Reference Manual. 3 edition (Universitaire Pers Maastricht, 2011).

19 Penders, B., Brecheisen, R., Gerver, A., van Zonneveld, G. \& Gerver, W. J. Validating Paediatric Morphometrics: body proportion measurement using photogrammetric anthropometry. Journal of pediatric endocrinology \& metabolism : JPEM 28, 1357-1362, doi:10.1515/jpem-2015-0172 (2015).

20 Gripp, K. W., Slavotinek, A. M., Hall, J. G. \& Allanson, J. E. Handbook of Physical Measurements. 3 edition, (Oxford University Press, United States of America, 2013).

21 Penders, B., Schott, N., Gerver, W. J. \& Stumpel, C. T. Body proportions in children with Kabuki syndrome. American journal of medical genetics. Part A 170, 610-614, doi:10.1002/ajmg.a.37467 (2016).

22 Verhagen, J. M., Oostdijk, W., Terwisscha van Scheltinga, C. E., Schalij-Delfos, N. E. \& van Bever, Y. An unusual presentation of Kabuki syndrome: clinical overlap with CHARGE syndrome. European journal of medical genetics 57, 510-512, doi:10.1016/j.ejmg.2014.05.005 (2014).

23 Patel, N. \& Alkuraya, F. S. Overlap between CHARGE and Kabuki syndromes: more than an interesting clinical observation? American journal of medical genetics. Part A 167A, 259-260, doi:10.1002/ajmg.a.36804 (2015). 



\section{Chapter 7 |}

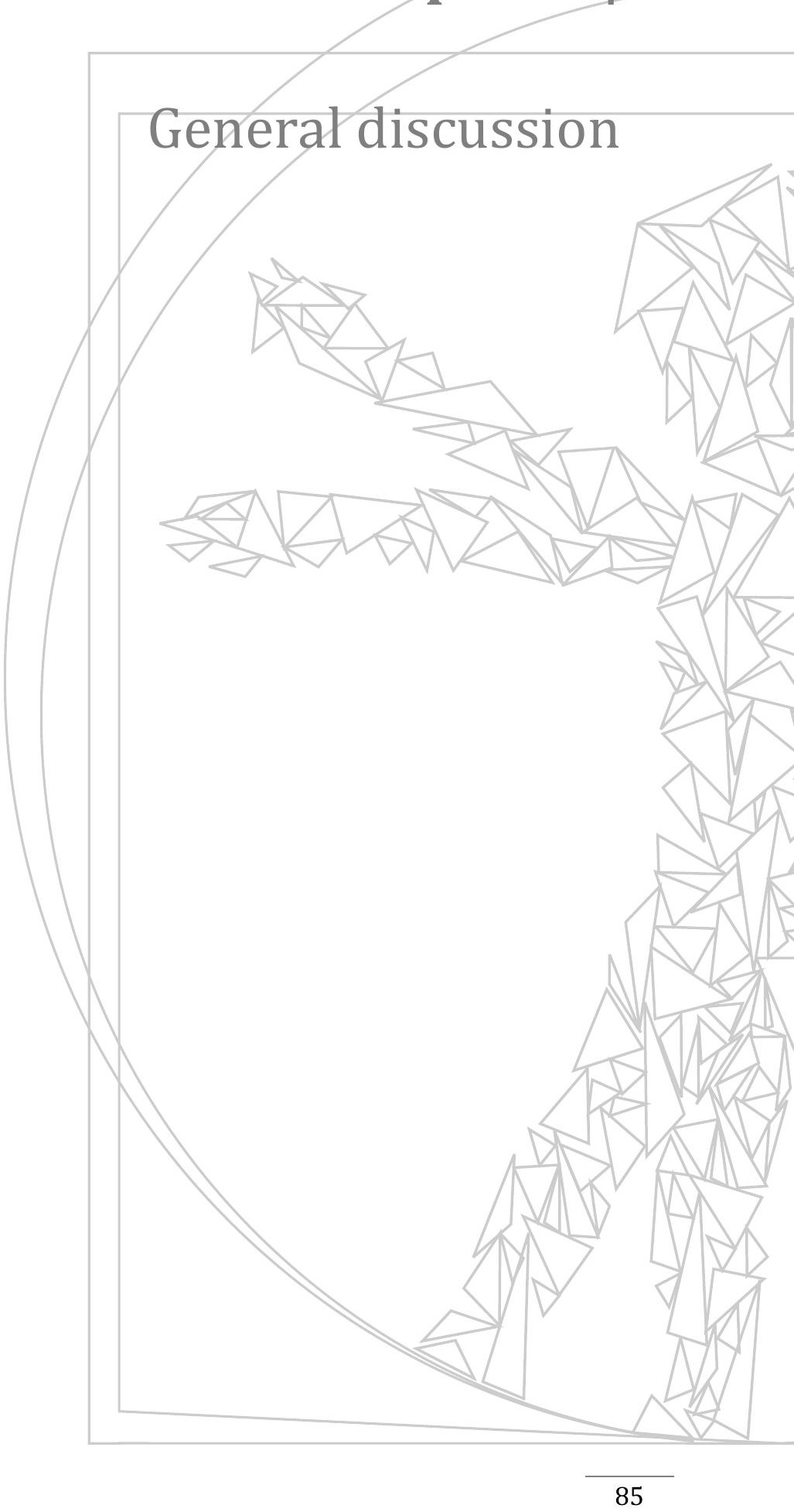





\section{Overview}

The continuous process of growth, which occurs throughout gestation, childhood and adolescence is reflected in the proportions of the human body. These are influenced by genetic, hormonal and environmental factors ${ }^{1}$. Selective regional growth causes an alteration of body proportions unique to every developmental stage and does not reoccur elsewhere in the maturation process. During the first year of life, the head grows most rapidly and its circumference even exceeds that of the chest. In addition, the extremities start out shorter than the trunk, yet these proportions reverse during childhood due to faster growth of the limbs, with the leg growth ceasing earlier than that of the arms. ${ }^{2,3}$. Disturbance in this sequence of growth and development may lead to disproportion and can hence be a clue in diagnostic processes or provide direction for treatment options. For example, patterns of disproportioned growth are displayed by certain syndromes, where the crux for adequate diagnosis and monitoring is in finding these patterns. This may be done by collecting a thorough representation of the body via various body proportions. However, collecting a multitude of precise physical measurements of a human body for the determination of body proportions is an arduous task, which requires specific anthropometric instruments and training of the measurer.

The purpose of this thesis is to provide an alternative to classic anthropometry, by investigating photogrammetric anthropometry; body proportion measurement based on photographs. Here, the accuracy and reliability of this new method are evaluated, as well as various applications for the obtained body proportions. These include investigation into the relationship between body proportions and body fat percentage for monitoring of weight and health status, and the gathering of insight into body proportions of genetic syndromes.

\section{This thesis set out to answer the following main research questions:}

- $\quad$ Can photogrammetric anthropometry be implemented as an accurate, fast and easy to use alternative to manual anthropometry in the measurement of body proportions in children?

- $\quad$ How can photogrammetric anthropometry contribute to the assessment of growth, health status and syndrome recognition in paediatric practice? 


\section{The validation of a new measuring method}

Three aspects were found to determine the reliability and accuracy of photogrammetric measurements: the technique of photography, the positioning of both the child and reference measure, and the training of the measurers. In the studies following the initial validation of the photometry technique these aspects were central in the evaluation of the photometry method and further determine its practical uses and applicability.

The reliability and accuracy of the photogrammetric method was investigated by comparing photogrammetric measurement to classical anthropometry. To critically evaluate this method, the two different types of anthropometric measurement errors were investigated, error related to reliability and error related to accuracy. Reliability is determined by the consistency of repeated measurements. Accuracy is determined by de amount of deviation from true values. The reliability is reflected by the inter-observer correlation between the same measurements, taken by different measurers. Here, it was shown to be $\geq 0.96$ for all photogrammetric measurements. For manual measurements this was $\geq 0.98$ and in concordance with previous studies in which the reliability of manual anthropometry has been investigated in children ${ }^{4,5}$.

The evaluation of the accuracy of anthropometric measurements, or photogrammetric measurements for that matter, is somewhat problematic. This is because the true value of any of these measurements is disputable, as no anthropometric measurements are free from measurement errors ${ }^{4,6}$. However, comparison of the manual measurements and photogrammetric measurements provided strong correlations ( $r$ 0.91-0.99) but showed that not all manual measurements are easily translatable into a photogrammetric counterpart. Most importantly, sitting height and arm span needed further investigation. It is not possible to determine sitting height in a frontal plane, and it proved to be difficult to determine the level of the buttocks on a lateral standing photograph. Therefore, a linear regression formula was calculated based on the distance between the nasal root and umbilicus. These body landmarks were chosen, as to be easily determined in the frontal plane and provided an acceptable estimation of sitting height with an $r^{2}$ of 0.94 compared to manual measurement. Additionally, arm span posed a challenge, as frontal photographs were made in anatomical position, to maximise the amount of measurements that could be performed. This differs from the standard position in which arm span is measured, namely with the arms completely extended horizontally from the body. A linear regression formula was shown to be able to provide a conversion factor to address this with an $r^{2}$ of 0.98 .

Based on these results, it was concluded that photogrammetric anthropometry is an accurate, valid alternative to classic anthropometry in the determination of body proportions in children. 


\section{Benefits}

Speed and ease of use were, apart from accuracy, key elements in the evaluation of the usefulness of the developed photometry method. When only height is warranted, manual measurement remains the fastest and easiest method. However, it was shown that when various measurements of the whole body are to be taken, photometry is evidently faster and more patient friendly. One of the key elements and benefits of photogrammetric anthropometry is that there is a separation between taking the photographs and performing the measurements. This eliminates the need for recurring outpatient visits solely for measurement, and the presence of the paediatrician is no longer obligatory to perform objective measurements. The photographs also provide a means to store the original data and perform additional measurements retroactively, without needing to trouble the patient once more. This makes photogrammetric anthropometry a serious consideration for large longitudinal studies.

Apart from the application of body proportion for the study of growth, additional uses of photogrammetric anthropometry were investigated. In the evaluation of development and health status of children, monitoring of growth with anthropometric measurements is fundamental in daily paediatric practice. Directly related to the health status and health risks of children is body fat percentage ${ }^{7-10}$. It is of clinical importance across the whole range of body weight, including children suffering from underweight to morbid obesity. Determination of body fat percentage has attracted attention in particular, since the prevalence of overweight and obesity in childhood is increasing worldwide ${ }^{11-14}$. Moreover, childhood obesity often tracks into adulthood, leading to an increased risk of complications later in life, such as metabolic syndrome and cardiovascular diseases $8,12,14$. Consequently, childhood obesity has become a major public health concern and methods to objectively monitor the health status of these children are a welcome sight. Due to the impracticability of various direct measurement methods for the determination of body fat percentage, such as deuterium dilution, air-displacement plethysmography and under-water weighing, BMI is most often used as a surrogate marker ${ }^{15-17}$.

As shown in this thesis, the ratio between biacromial width and waist width provided a strong relationship with body fat percentage $(r-0.92)$ and a linear regression model was made, based on these findings. An accurate estimation of body fat percentage could be made, regardless of body weight and independent of age and gender with an $r^{2}$ of 0.85 and a median difference in fat mass of $3.6 \%$ compared to measurement via deuterium dilution and air-displacement plethysmography.

This new method was shown to be highly comparable, and even superior to estimation of body mass percentage via BMI-z score $(r-0.86)$. Since it is fast and easy to use, it could well be a valuable tool in population-based research, especially when combined with a wealth of information on body proportions, all in a single photograph. 
This new development may also positively influence the child's emotional experience in the monitoring of overweight and obesity. Namely, physically performing the measurements need no longer be necessary. Also, as discussed earlier, the need for recurring outpatient visits solely for measurement and the presence of the paediatrician is no longer obligatory to perform objective measurements. Furthermore, the potential to store the photographs and original data, truly enhances monitoring and comparability capacity over time, above simply observing body weight or BMI values.

Apart from investigation of the relationship between body proportions and body fat percentage, the photometry method was evaluated for gathering of insight into body proportions in two genetic syndromes, Kabuki syndrome and CHARGE syndrome. These specific syndromes were chosen, since growth and developmental aberrations have been described in both, with no in-depth information on body proportions available18-25.

Determination of a broad range of body proportions in children with Kabuki syndrome, showed that these children differ significantly from normally proportioned controls. They were shown to have smaller heads and longer arms proportional to their trunks and were found to have longer upper arms proportional to their tibia length and feet. In the evaluation of CHARGE syndrome, it was determined in this thesis that these children appear to have a shorter trunk in proportion to their height, head length and arms. Also, children with CHARGE syndrome have, on average, smaller feet proportional to their tibia length opposed to controls. Interestingly, for both CHARGE and Kabuki syndrome, no clear differences in change of body proportions with age are observed between these children and normally proportioned controls. This leads to believe that, although proportions are different, the developmental process of selective regional growth might not be influenced by the genetic aberrations present in these syndromes.

Additionally, when performing the measurements in children with Kabuki and CHARGE syndrome, an added strength of the photometry method was found. When using photogrammetric anthropometry, several photographs can be combined to perform the measurements and not one ideal pose has to be found. This was found to be especially helpful since careful positioning of these children is difficult and sometimes impossible, which predominantly hampers manual measurements. This proved to be more patient-friendly than manual measurements, and also less frustrating for the observers. 


\section{The use of photogrammetric anthropometry in other fields of study}

Photogrammetric anthropometry found its origin in 1940 in the proposals by William Sheldon ${ }^{26}$. However, the foundation of this method, with guidelines on practical applicability and measurement technique for both adults and children is based on the works of James Tanner (figure 1).
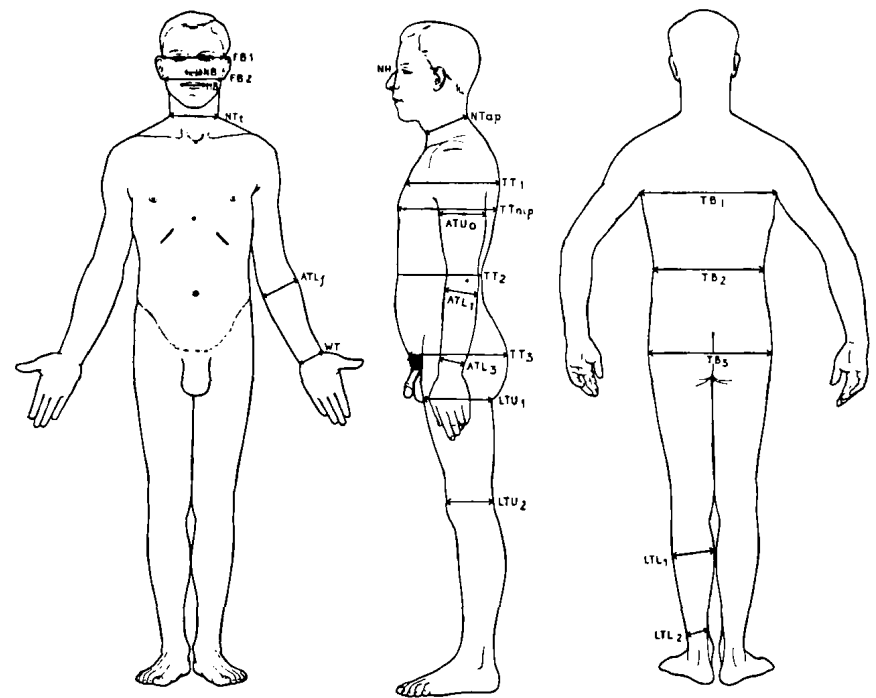

Figure 1 | Measurements taken from photograph. Left: front view; middle: side view; right: back view; From Tanner, J. M. \& Weiner, J. S. The reliability of the photogrammetric method of anthropometry, with a description of a miniature camera technique. American journal of physical anthropology 7, 145-186 (1949).

Results in male adults showed that photogrammetric measurements can be as reliable as classic anthropometric measurements ${ }^{27,28}$.

However, studies with implementation of photogrammetric anthropometry have since been scarce, and extensive studies in children were, to date, not performed. Currently, photogrammetric methods are used most frequently in orthopaedics and craniofacial studies ${ }^{29,30}$. As also observed in this thesis, a photogrammetric application allows for quick measurement of the entire body or certain body parts. In the field of orthopaedics this is primarily implemented in screening of spinal curvatures and posture in de management of scoliosis ${ }^{31,32}$. In craniofacial studies, the value of implementation of photogrammetric measurement techniques has also been recognised to quantify craniofacial dysmorphology33-35. Three-dimensional modelling methods have shown their worth in treatment management in dentistry and reconstructive surgery ${ }^{36,37}$. All these applications show the diversity of photogrammetric methods and gave incentive to explore further uses in the measurement of body proportions of the whole body as done in this thesis. 


\section{Two-dimensional versus three-dimensional}

Opposed to two-dimensional photogrammetric anthropometry, as described in this thesis, recent studies have investigated the use of three-dimensional body scanners as an alternative to classic anthropometry. Initially developed for the clothing industry, these scanners have made their debut as healthcare applications for evaluation of nutritional status and developmental normality. Several techniques have been developed, based on 2D silhouette images, laser-based scanning and radio-wave linear arrays ${ }^{38}$. There are several similarities between the $2 \mathrm{D}$ and $3 \mathrm{D}$ measuring methods: both are non-invasive and surpass conventional anthropometry in performing a multitude of measurements of a human body in a short amount of time.

The accuracy of 3D body scanning appears to be similar to photogrammetric anthropometry ( $r$ 0.90-0.97) when compared to manual measurements ${ }^{39-41}$. There is, however, a difference in which measurements can be taken with both measuring methods. The nature of the 2D photograph in photogrammetric anthropometry limits the user to performing one- and two-dimensional measurements, i.e., linear and areal measures. Since these measurements include the classical measurements of height, biacromial width, biiliacal width, arm span and the length of extremities, this was an important incentive in this thesis to explore the photogrammetric anthropometry method instead of a 3D alternative. However, this means conceding to not being able to take circumference measurements, as waist and hip circumference. Nevertheless, this issue was addressed, since width measurements were found to show a strong correlation with the circumference measurements $(r$ 0.86-0.95). Also, determination of body surface area, is not possible on a $2 \mathrm{D}$ photograph.

Body scanners, however, excel at measuring circumference measurements and body surface area, due to the three-dimensional nature of the measurement object provided ${ }^{38}$. However, linear measurements such as height, biacromial width or biiliacal width are often not performed and viewed as problematic, since determination of appropriate landmarks on the body surface appears to be difficult for some software algorithms and highly dependent on posture and behaviour of subjects during scanning. ${ }^{40,42}$. Namely, depending on the scan method, it is necessary for subjects to stand motionless for 8-10 seconds while holding their breath, which would limit its use in paediatric and disabled patients ${ }^{39,42}$. In photogrammetric anthropometry, posture and determination of body landmarks is of equal importance, but since taking a photograph is significantly faster than scanning, there is lower risk of error due to patient movement.

Furthermore, it is important to note that the apparatus, technique and software necessary to perform 3D body scanning is considerably more sophisticated and expensive than materials used in photogrammetric anthropometry. This is reflected 
in studies reporting that successful body scans can sometimes only be obtained in $70.7 \%$ of the cases due to body movement or software inability to extract shape ${ }^{39}$. This concludes that 2D and 3D measuring methods need not compete with each other, since they excel at different aspects. In practice, the desired outcome should determine which method is to be used. As practicality and ease of use are important pillars in this thesis in the investigation of a new measuring method for body proportions, a two-dimensional method based on digital photographs was deemed the more attractive choice.

\section{Future applications, the next step}

The development of photogrammetric anthropometry will be a continuous process. There are several components on which future studies will be focused. Effort needs to be put into bridging the gap between taking the photographs and performing the measurements. In the current situation, it is still necessary to manually upload the photographs into the photometry software before measurements can be performed. This is of no concern in research settings, however, when facilitating photometry for daily paediatric practice, it needs to be made possible to perform the measurements during the patient's visit. A possible solution may be the development of a mobile application in which both photograph and photometry software can be combined.

To further expedite the implementation of photogrammetric anthropometry and to make it more attractive for practical use, steps need to be taken in measurement automation. This will diminish the amount of training necessary for measurers and save time. Similar steps have been taken in other measurement methods, such as automated bone age assessment and measurements by $3 \mathrm{D}$ body scanners. This will however bring additional challenges in the determination of the appropriate landmarks and software development.

Additionally, it is the intention to further diminish the necessity of outpatient visits solely for anthropometric measurements in, for example, the monitoring of growth and body weight. Therefore, photographs and measurements performed by parents or caretakers of the children at home, instead of a paediatrician will be part of future studies. This will provide additional challenges when adhering to correct photography technique, positioning and training. However, these may coincide with the automation process to achieve the same goal; making photogrammetric anthropometry a fast, easy to use measuring method for body proportions in daily paediatric practice.

As future efforts will focus on expanding the use of the photometry software, also to third parties, it is of vital importance that strict security measures are taken for preserving patient privacy and confidentially of this sensitive information. There will need to be a balance between storing as much of the original data as possible and anonymising it at the same time. One of the possible solutions would be to 


\section{Chapter 7}

provide a means to save only the silhouette of the patient, instead of the original photograph, which would preserve most measurements and make the data almost completely unidentifiable.

Apart from further development of the photometry method, additional research will be aimed to broaden our understanding of child development and body proportions in various aspects. As photogrammetric anthropometry holds great potential for longitudinal and field studies, these will be the next step. Additionally, a lot of progress can still be made in the evaluation of body proportions and growth in a broad range of genetic syndromes for diagnostic purposes and treatment options, of which the first efforts have here been presented in children with Kabuki and CHARGE syndrome.

In conclusion, the future looks bright and exciting for photogrammetric anthropometry. This thesis provides a stepping stone for anthropometry, and especially the measurement of body proportions to reclaim its place as an essential part of daily paediatric practice. 


\section{References}

1 Gripp, K. W., Slavotinek, A. M., Hall, J. G. \& Allanson, J. E. Handbook of Physical Measurements. 3th edition, (Oxford University Press, United States of America, 2013).

2 Medawar, P. B. The shape of the human being as a function of time. Proceedings of the Royal Society of London. Series B - Biological Sciences 132, 133-141, doi:10.1098/rspb.1944.0008 (1944).

3 Tanner, J. M. Normal growth and techniques of growth assessment. Clinics in endocrinology and metabolism 15, 411-451 (1986).

4 Ulijaszek, S. J. \& Kerr, D. A. Anthropometric measurement error and the assessment of nutritional status. Br J Nutr 82, 165-177 (1999).

5 Reliability of anthropometric measurements in the WHO Multicentre Growth Reference Study. Acta paediatrica (Oslo, Norway : 1992). Supplement 450, 38-46 (2006).

6 Kouchi, M., Mochimaru, M., Tsuzuki, K. \& Yokoi, T. Interobserver errors in anthropometry. Journal of human ergology 28, 15-24 (1999).

7 Zhu, S., Wang, Z., Shen, W., Heymsfield, S. B. \& Heshka, S. Percentage body fat ranges associated with metabolic syndrome risk: results based on the third National Health and Nutrition Examination Survey (1988-1994). Am J Clin Nutr 78, 228-235 (2003).

8 Neovius, M., Linné, Y., Barkeling, B. \& Rössner, S. Discrepancies between classification systems of childhood obesity. Obes Rev 5, 105-114, doi:10.1111/j.1467-789X.2004.00136.x (2004).

9 Cole, T. J. \& Lobstein, T. Extended international (IOTF) body mass index cut-offs for thinness, overweight and obesity. Pediatr Obes 7, 284-294, doi:10.1111/j.2047-6310.2012.00064.x (2012).

10 Gishti, 0. et al. Body fat distribution, metabolic and inflammatory markers and retinal microvasculature in school-age children. The Generation R Study. International journal of obesity 39, 1482-1487, doi:10.1038/ijo.2015.99 (2015).

11 Dera-de Bie, E., Gerver, W. J. \& Jansen, M. Training program for overweight prevention in the child's first year: compilation and results. Nursing \& health sciences 15, 387-397, doi:10.1111/nhs.12051 (2013).

12 Freedman, D. S. \& Sherry, B. The validity of BMI as an indicator of body fatness and risk among children. Pediatrics 124 Suppl 1, S23-34, doi:10.1542/peds.2008-3586E (2009).

13 Cole, T. J., Bellizzi, M. C., Flegal, K. M. \& Dietz, W. H. Establishing a standard definition for child overweight and obesity worldwide: international survey. BMJ 320, 1240-1243 (2000).

14 Fredriks, A. M., Van Buuren, S., Sing, R. A. H., Wit, J. M. \& Verloove-Vanhorick, S. P. Alarming prevalences of overweight and obesity for children of Turkish, Moroccan and Dutch origin in The Netherlands according to international standards. Acta Paediatr 94, 496-498 (2005).

15 Goulding, A. et al. DEXA supports the use of BMI as a measure of fatness in young girls. International journal of obesity and related metabolic disorders : journal of the International Association for the Study of Obesity 20, 1014-1021 (1996).

16 Pietrobelli, A. et al. Body mass index as a measure of adiposity among children and adolescents: a validation study. The Journal of pediatrics 132, 204-210 (1998).

17 Lindsay, R. S. et al. Body mass index as a measure of adiposity in children and adolescents: relationship to adiposity by dual energy $\mathrm{x}$-ray absorptiometry and to cardiovascular risk factors. J Clin Endocrinol Metab 86, 4061-4067, doi:10.1210/jcem.86.9.7760 (2001).

18 Niikawa, N., Matsuura, N., Fukushima, Y., Ohsawa, T. \& Kajii, T. Kabuki make-up syndrome: a syndrome of mental retardation, unusual facies, large and protruding ears, and postnatal growth deficiency. The Journal of pediatrics 99, 565-569 (1981).

19 Schrander-Stumpel, C. T., Spruyt, L., Curfs, L. M., Defloor, T. \& Schrander, J. J. Kabuki syndrome: Clinical data in 20 patients, literature review, and further guidelines for preventive management. American journal of medical genetics. Part A 132a, 234-243, doi:10.1002/ajmg.a.30331 (2005).

20 Wilson, G. N. Thirteen cases of Niikawa-Kuroki syndrome: report and review with emphasis on medical complications and preventive management. American journal of medical genetics 79, 112 120 (1998). 
21 Mhanni, A. A., Cross, H. G. \& Chudley, A. E. Kabuki syndrome: description of dental findings in 8 patients. Clinical genetics 56, 154-157 (1999).

22 Shotelersuk, V., Punyashthiti, R., Srivuthana, S. \& Wacharasindhu, S. Kabuki syndrome: report of six Thai children and further phenotypic and genetic delineation. American journal of medical genetics 110, 384-390, doi:10.1002/ajmg.10474 (2002).

23 Blake, K., Kirk, J. M. \& Ur, E. Growth in CHARGE association. Archives of disease in childhood 68, 508509 (1993).

24 Legendre, M. et al. Antenatal spectrum of CHARGE syndrome in 40 fetuses with CHD7 mutations. Journal of Medical Genetics 49, 698-707, doi:10.1136/jmedgenet-2012-100926 (2012).

25 Dorr, H. G., Madeja, J. \& Junghans, C. Spontaneous postnatal growth is reduced in children with CHARGE syndrome. Acta Paediatr 104, e314-318, doi:10.1111/apa.12980 (2015).

26 Sheldon, W. H. The Varieties of Human Physique. New York: Harper \& Brothers (1940).

27 Tanner, J. M. \& Weiner, J. S. The reliability of the photogrammetric method of anthropometry, with a description of a miniature camera technique. American journal of physical anthropology 7, 145186 (1949).

28 Dupertuis, C. W. \& Tanner, J. M. The pose of the subject for photogrammetric anthropometry, with especial reference to somatotyping. American journal of physical anthropology 8, 27-48, doi:10.1002/ajpa.1330080111 (1950).

29 Mitchell, H. L. \& Newton, I. Medical photogrammetric measurement: overview and prospects. ISPRS Journal of Photogrammetry and Remote Sensing 56, 286-294, doi:https://doi.org/10.1016/S09242716(02)00065-5 (2002).

30 Ey-Chmielewska, H., Chrusciel-Nogalska, M. \& Fraczak, B. Photogrammetry and Its Potential Application in Medical Science on the Basis of Selected Literature. Advances in clinical and experimental medicine : official organ Wroclaw Medical University 24, 737-741, doi:10.17219/acem/47679 (2015).

31 Saad, K. R., Colombo, A. S. \& João, S. M. A. Reliability and validity of the photogrammetry for scoliosis evaluation: a cross-sectional prospective study. J Manipulative Physiol Ther 32, 423-430, doi:10.1016/j.jmpt.2009.06.003 (2009).

32 Minguez, M. F. et al. Quantifier variables of the back surface deformity obtained with a noninvasive structured light method: evaluation of their usefulness in idiopathic scoliosis diagnosis. European spine journal : official publication of the European Spine Society, the European Spinal Deformity Society, and the European Section of the Cervical Spine Research Society 16, 73-82, doi:10.1007/s00586-006-0079-y (2007).

33 Han, K., Kwon, H. J., Choi, T. H., Kim, J. H. \& Son, D. Comparison of anthropometry with photogrammetry based on a standardized clinical photographic technique using a cephalostat and chair. J Craniomaxillofac Surg 38, 96-107, doi:10.1016/j.jcms.2009.04.003 (2010).

34 Anic-Milosevic, S., Mestrovic, S., Prlić, A. \& Slaj, M. Proportions in the upper lip-lower lip-chin area of the lower face as determined by photogrammetric method. J Craniomaxillofac Surg 38, 90-95, doi:10.1016/j.jcms.2009.03.013 (2010).

35 Wong, J. Y. et al. Validity and reliability of craniofacial anthropometric measurement of 3D digital photogrammetric images. The Cleft palate-craniofacial journal : official publication of the American Cleft Palate-Craniofacial Association 45, 232-239, doi:10.1597/06-175 (2008).

36 Jayaratne, Y. S., Lo, J., Zwahlen, R. A. \& Cheung, L. K. Three-dimensional photogrammetry for surgical planning of tissue expansion in hemifacial microsomia. Head \& neck 32, 1728-1735, doi:10.1002/hed.21258 (2010).

37 Mertens, C. et al. The value of three-dimensional photogrammetry in isolated sagittal synostosis: Impact of age and surgical technique on intracranial volume and cephalic index\&\#x2500;a retrospective cohort study. Journal of Cranio-Maxillo-Facial Surgery 45, 2010-2016, doi:10.1016/j.jcms.2017.09.019.

38 Treleaven, P. \& Wells, J. 3D Body Scanning and Healthcare Applications. Vol. 40 (2007). 
39 Wells, J. C. et al. Acceptability, Precision and Accuracy of 3D Photonic Scanning for Measurement of Body Shape in a Multi-Ethnic Sample of Children Aged 5-11 Years: The SLIC Study. PloS one 10, e0124193, doi:10.1371/journal.pone.0124193 (2015).

40 Kuehnapfel, A., Ahnert, P., Loeffler, M., Broda, A. \& Scholz, M. Reliability of 3D laser-based anthropometry and comparison with classical anthropometry. Scientific Reports 6, 26672, doi:10.1038/srep26672 (2016).

41 Glock, F. et al. Validity and intraobserver reliability of three-dimensional scanning compared with conventional anthropometry for children and adolescents from a population-based cohort study. Pediatr Res 81, 736-744, doi:10.1038/pr.2016.274 (2017).

42 Wang, J. et al. Validation of a 3-dimensional photonic scanner for the measurement of body volumes, dimensions, and percentage body fat. Am J Clin Nutr 83, 809-816 (2006). 



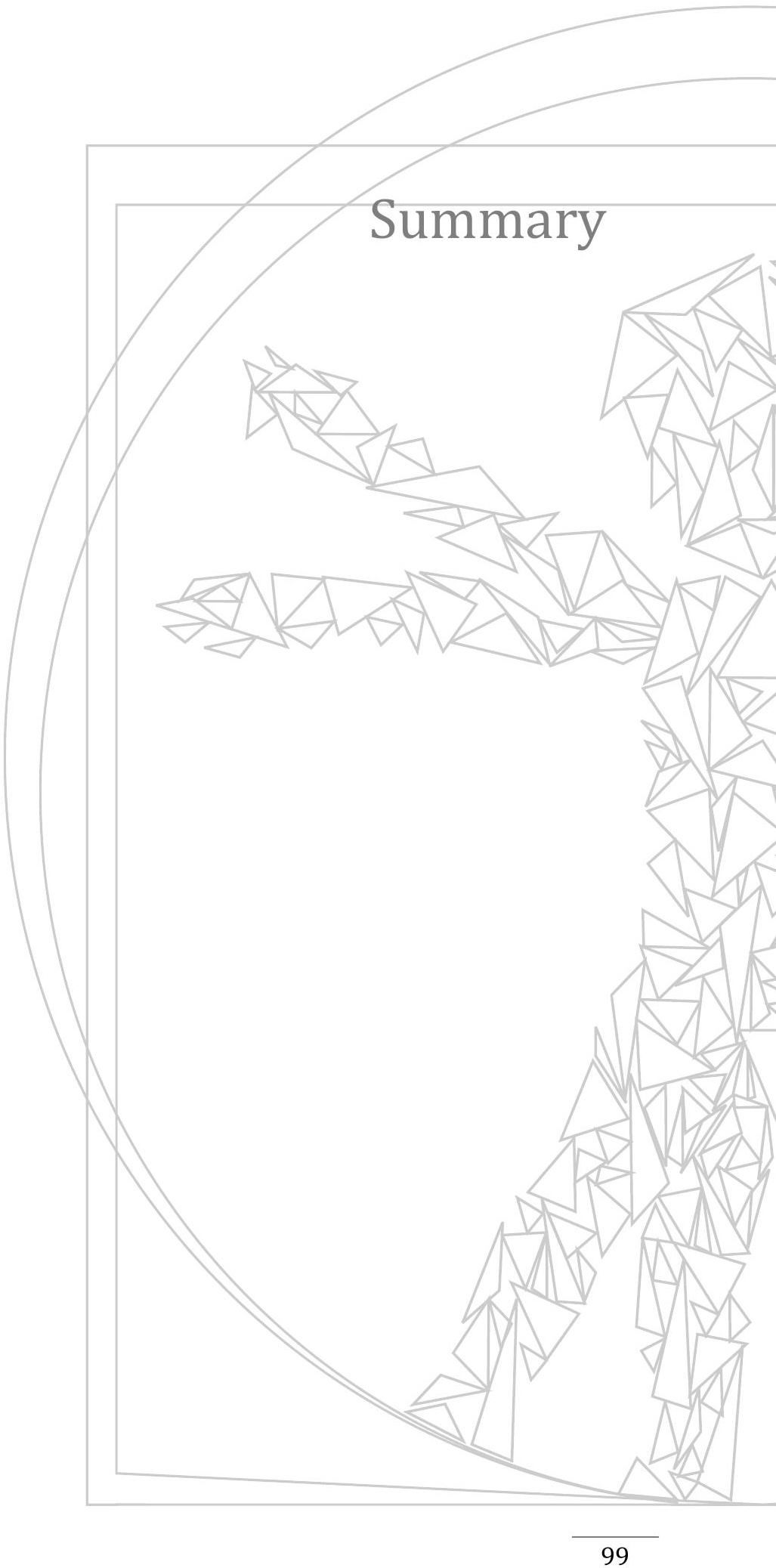





\section{Summary}

Anthropometry is the study of the measurement of the human body. These measurements are classically performed manually, with specialised instruments and can be implemented to evaluate growth, development and health status in children. Since individual parts of the human body develop at different speeds, this results in a unique pattern of development, which can be quantified by the interrelationship between various linear measurements as body proportions. Thus, when abnormal body proportions occur, due to an imbalance of growth of either the whole body or certain body parts, this hallmarks a disturbance in the natural process of maturation, which can provide recognisable patterns of particular diseases or syndromes. Therefore, knowledge of body proportions is essential in judging patients' development, in making diagnoses and in evaluating therapeutic interventions. However, collecting a multitude of manual measurements of a human body for the determination of body proportions is an arduous task. Therefore, this thesis focusses on the investigation of a new measuring method of body proportions based on digital photographs, photogrammetric anthropometry. The main purpose is to reinvent photogrammetric anthropometry, explore its strengths and weaknesses, and the diversity of its uses.

It is shown in this thesis that photogrammetric anthropometry, as a method of measurement of the body proportions of a child, can be done in an accurate and reliable way. Further uses of this new technique were investigated to evaluate its potential in the monitoring of health status in children and in gathering more insight into body proportions of genetic syndromes.

To contribute in the monitoring of health status in children, it was investigated if body proportions, measured with photogrammetric anthropometry, could estimate body fat percentage. A strong correlation was demonstrated between biacromial width and waist width, which provided the basis of a linear regression model that can accurately estimate body fat percentage in children, regardless of weight classification and independent of age and gender, compared to measurements using deuterium dilution and air-displacement plethysmography.

For gathering more insight into the body proportions of genetic syndromes, the photometry technique was implemented in both Kabuki syndrome and CHARGE syndrome. In children with Kabuki syndrome, it was shown that body proportions, measured with photogrammetric anthropometry, were able to discern these children from normally proportioned controls. The key differences in body proportions in Kabuki syndrome are that these children have smaller heads and longer arms proportional to their trunks and longer upper arms proportional to their tibia length and feet. Also, in CHARGE syndrome, significant differences in body proportions were observed, opposed to normally proportioned controls. Children with CHARGE syndrome appear to have a shorter trunk in proportion to their height, 
head length and arm length. Also, smaller feet proportional to tibia length were noted. The possibility to combine several photographs to perform the measurements was found to be especially helpful since careful positioning of these children is difficult and sometimes impossible, which predominantly hampers manual measurements.

Overall, the main advantages of photometry in comparison to manual anthropometry are that photometry reduces the time needed to perform multiple measurements and that there is a division between taking the photographs and performing the measurements. This can eliminate the need for recurring outpatient visits, solely for measurements, since the paediatrician does not need to be present when the photographs are taken. Additionally, this technique also provides a means to store original data, which makes performing additional measurements and comparison in a later stadium possible, without further burdening the child.

Future research will focus on further developing photogrammetric anthropometry to become an attractive and easy to use measuring method for daily paediatric practice. This will include efforts to streamline the process between taking the photographs and performing the measurements and to automatise actions where possible.

In conclusion, this thesis provides validation for a new method for measurement of body proportions in children. Furthermore, the first steps in the exploration of its assets and possible applications were made. These include, a tool in monitoring of health status via estimation of body fat percentage and study of body proportions in two genetic syndromes. Its purpose is to provide a means to further our understanding of growth and development in children. 




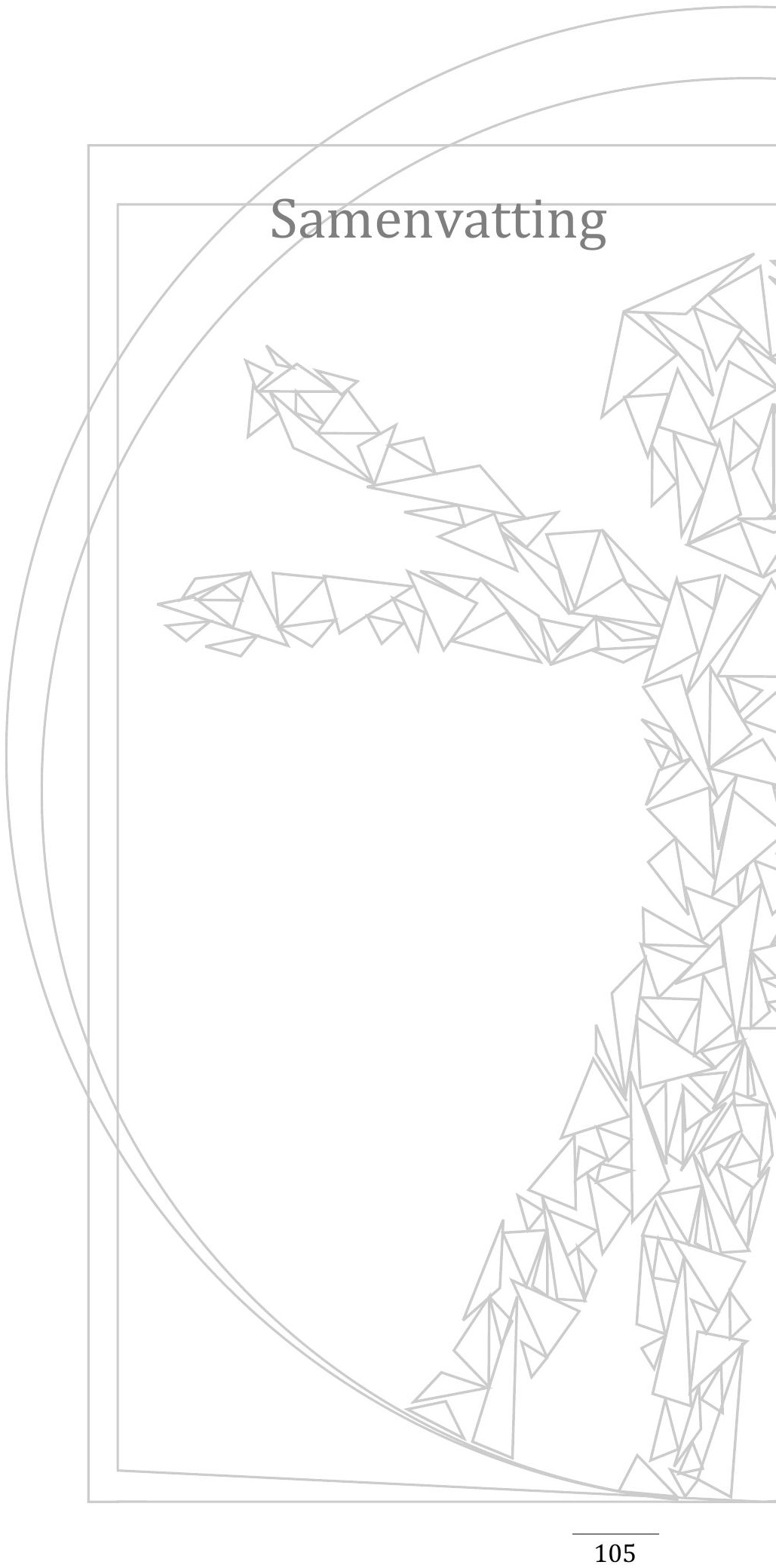





\section{Samenvatting}

Antropometrie is de studie van het meten van het menselijk lichaam. Deze metingen worden vanouds met de hand gedaan, gebruikmakend van gespecialiseerde meetinstrumenten. Vervolgens worden deze gebruikt om groei, ontwikkeling en de algehele gezondheidsstatus van kinderen te beoordelen. Aangezien de onderdelen van het menselijk lichaam met verschillende snelheden groeien, resulteert dit in een uniek patroon van ontwikkeling. Dit patroon kan derhalve gekwantificeerd worden door de onderlinge relatie van verschillende lineaire metingen, als zijnde lichaamsproporties. Wanneer er vervolgens abnormale lichaamsproporties worden waargenomen, door een disbalans in groei van ofwel het gehele lichaam of specifieke lichaamsdelen, kenmerkt dit een verstoring van het natuurlijke ontwikkelingsproces. Deze verstoring kan herkenbare patronen van specifieke ziektebeelden of syndromen opleveren. Derhalve is kennis van lichaamsproporties essentieel in het beoordelen van de ontwikkeling van kinderen, in diagnosestelling en het evalueren van therapeutische interventies.

Desalniettemin is het verzamelen van een veelvoud aan manuele metingen van het menselijk lichaam voor het bepalen van lichaamsproporties een tijdrovende taak. Daarom focust dit proefschrift op het onderzoeken van een nieuwe meetmethode van lichaamsproporties, gebaseerd op digitale foto's, genaamd fotometrische antropometrie. Het hoofddoel is om deze techniek opnieuw vorm te geven en de voor- en nadelen en scala aan toepassingen te onderzoeken.

Dit proefschrift laat zien dat fotometrische antropometrie een accurate en betrouwbare manier is om de lichaamsproporties van kinderen te meten. Additionele toepassingen zijn onderzocht om het potentieel van deze nieuwe techniek te onderzoeken in de monitoring van de gezondheidsstatus van kinderen en in het vergaren van meer inzicht in de lichaamsproporties van verschillende genetische syndromen.

Om bij te dragen in het in kaart brengen en volgen van de gezondheidsstatus van kinderen is onderzocht of met behulp van lichaamsproporties, gemeten met fotometrische antropometrie, een inschatting van het percentage lichaamsvet gemaakt kon worden. Er werd een sterke correlatie gezien tussen het percentage vetmassa en de ratio tussen de schouderbreedte en grootste breedte van de buik. Dit voorzag in de basis van een lineair regressiemodel welke in staat is een accurate inschatting van het lichaamsvetpercentage in kinderen te geven. Dit blijkt mogelijk, ongeacht de gewichtsclassificatie en onafhankelijk van leeftijd en geslacht, vergeleken met deuterium dilutie en luchtverplaatsings-plethysmografie.

Tijdens het vergaren van meer inzicht in de lichaamsproporties van verschillende syndromen, werd de fotometrie techniek ingezet in onderzoek naar zowel Kabuki syndroom als CHARGE syndroom. Bij kinderen met Kabuki syndroom werd gezien dat op basis van de lichaamsproporties, gemeten met fotometrische antropometrie, 
onderscheid gemaakt kon worden met normaal geproportioneerde controle patiënten. De belangrijkste verschillen tussen deze kinderen blijken te zijn dat kinderen met Kabuki syndroom een relatief kleiner hoofd en langere armen in verhouding tot hun romp hebben en langere bovenarmen in verhouding tot hun tibialengte en voetlengte. Ook in kinderen met CHARGE syndroom werden significante verschillen in lichaamsproporties opgemerkt. Kinderen met CHARGE syndroom blijken een kortere romp te hebben in verhouding tot hun lichaamslengte, hoofdlengte en armlengte. Ook werden kleinere voeten in verhouding tot tibia lengte gezien. In beide studies werd de mogelijkheid tot het combineren van verschillende foto's in het uitvoeren van de metingen als bijzonder nuttig bevonden, gezien het nauwkeurig positioneren van deze kinderen lastig en soms zelfs onmogelijk is.

Samenvattend zijn de belangrijkste voordelen van de fotometrie, in vergelijking met manuele antropometrie, een reducering van tijd voor het uitvoeren van een veelvoud aan metingen. Tevens hoeven de metingen niet per se uitgevoerd te worden ten tijde van het maken van de foto. Dit kan ervoor zorgen dat terugkerende poliklinische bezoeken, enkel voor het uitvoeren van metingen niet meer nodig hoeven te zijn. Ook is het met deze techniek mogelijk om de originele data te bewaren. Dit maakt het mogelijk om additionele metingen te verrichten en vergelijkingen in een later stadium uit te voeren zonder dat het kind opnieuw gezien en belast hoeft te worden.

Toekomstig onderzoek zal focussen op het verder ontwikkelen van de fotometrische antropometrie om het een aantrekkelijke en vooral een eenvoudig te gebruiken meetmethode te maken voor gebruik in de dagelijkse praktijk. Hiervoor zullen er inspanningen verricht dienen te worden om het proces van het nemen van de foto's tot het uitvoeren van de metingen te stroomlijnen en, waar mogelijk, acties in het meetproces te automatiseren.

Concluderend verschaft dit proefschrift validatie voor een nieuwe methode om lichaamsproporties te meten bij kinderen. Hiernaast zijn de eerste stappen genomen in de exploratie van de voor- en nadelen en applicatiemogelijkheden van deze techniek. Deze bevatten onder andere een manier om de gezondheidsstatus van kinderen te monitoren door een inschatting van het lichaamsvetpercentage te kunnen maken en onderzoek naar lichaamsproporties bij twee genetische syndromen. Het overkoepelende doel is om een manier te verschaffen om onze kennis van groei en ontwikkeling bij kinderen te vergroten. 




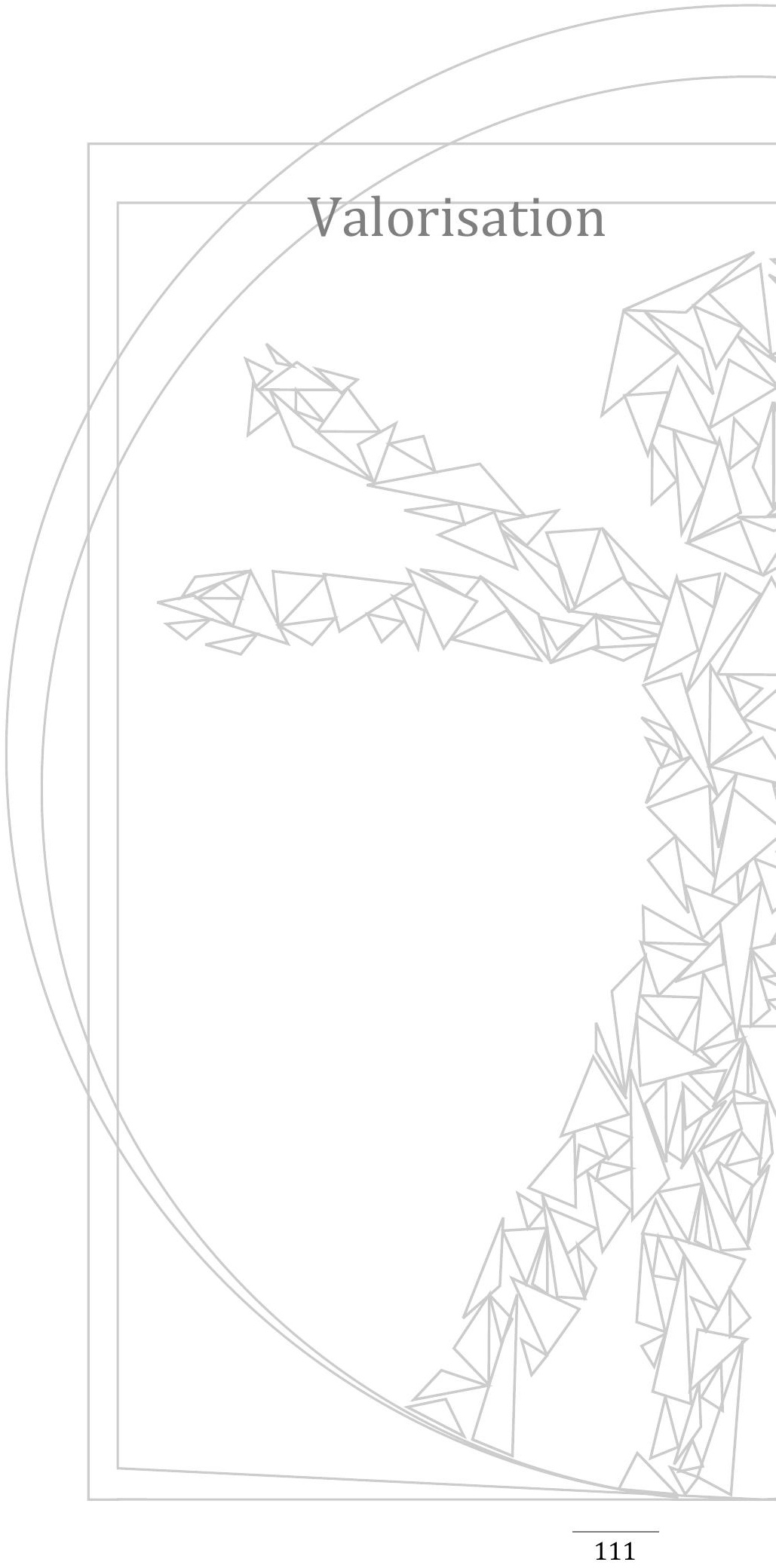





\section{Valorisation}

\section{Relevance}

The measurement the human body, known as anthropometry, is the cornerstone of paediatric practice in de assessment of growth and development. It is often implemented in its most essential form, in the measurement of body weight and height. When insight into the proportional growth is warranted, sitting height, might be included, however this is often reserved for a specific patient population of the paediatric endocrinologist. Knowledge on the relevance of other body proportions might be scarce and the need for specialised instruments and training to perform accurate measurements might dampen the interest of paediatricians and other healthcare professionals. It is, however, important to stress the relevance of insight into body proportions, as change in these proportions across the whole body reflect the summation of human growth and development, and are influenced and guided by genetic, hormonal and environmental factors. Therefore, knowledge of body proportions is essential in judging patients' development, in making diagnoses and in evaluating therapeutic interventions.

\section{Target population and implementation in clinical practice}

The development of the photogrammetric anthropometry technique, as described in this thesis, aims to further explore the relevance and diversity of applications for the measurement of body proportions. The core idea in these explorations is the possibility for fast and easy application in daily practice, as limiting oneself to dedicated and sophisticated technology hampers practical value outside of research settings. Therefore, use of digital photographs, which can nowadays be acquired at high quality with relatively inexpensive equipment is an important advantage of this new technique over, for example, 3D body scanners. Apart from streamlining the measurement of multiple body proportions, which is of great value in the study of growth in the field of endocrinology and genetics, it is also shown in this thesis that measurement of body proportions provides a reliable estimation of body fat percentage in children. This makes reliable assessment of adiposity in children more accessible for use in daily paediatric practice, without need for expensive or cumbersome measurement methods, mostly reserved for research settings, such as deuterium dilution, underwater weighing or air-displacement plethysmography. The target population of the photometry technique is the practicing paediatrician and health care provider in community health care services, which this thesis hopes to provide with an attractive, diverse, new tool for the implementation of anthropometry. 



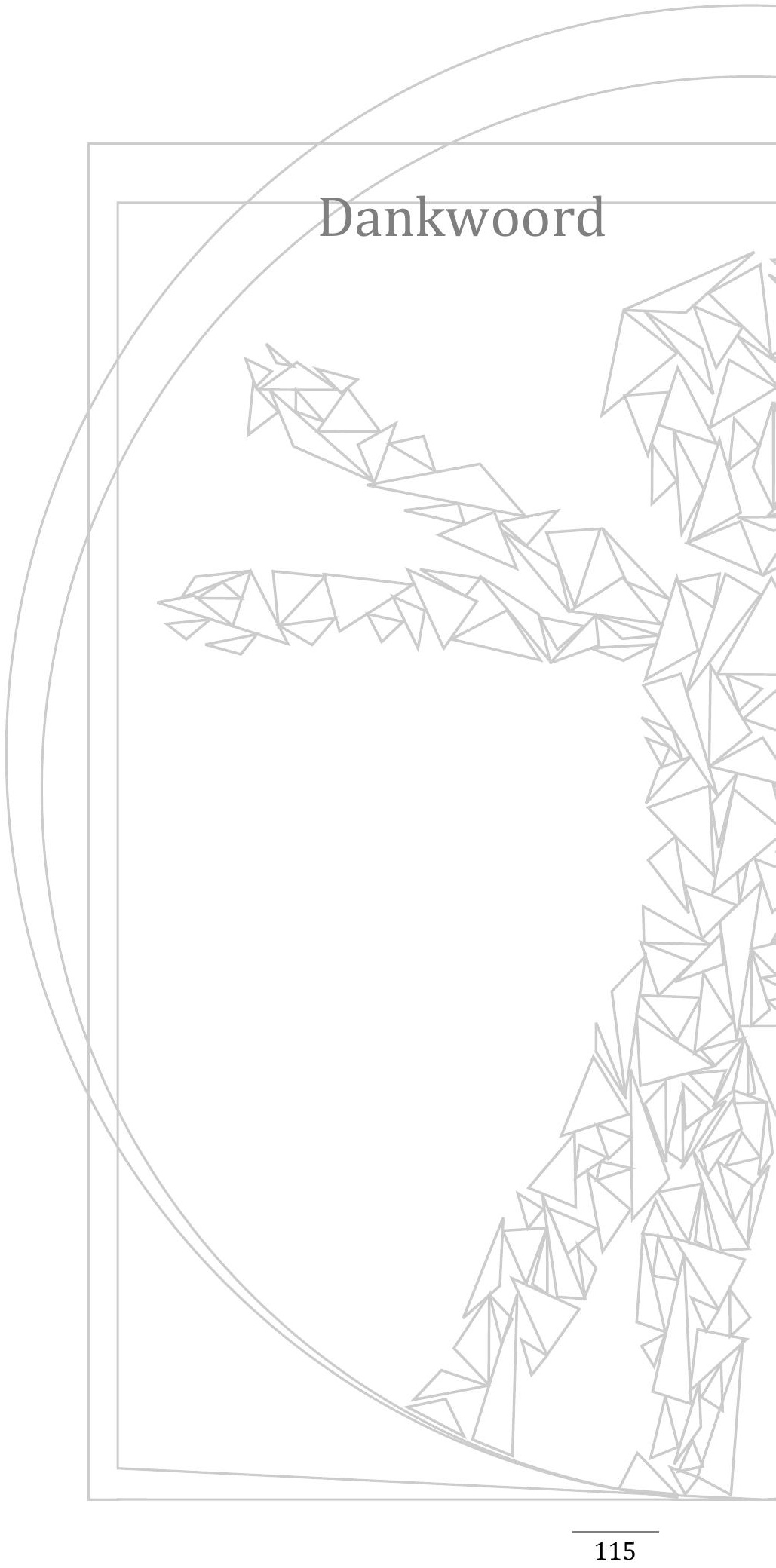





\section{Dankwoord}

\section{"Mien beukske is klaor"}

Ik wil iedereen die op welke manier dan ook heeft bijgedragen aan de totstandkoming van dit proefschrift, heel hartelijk danken. Als eerste wil ik alle kinderen en ouders danken voor hun medewerking. Hiernaast zijn er een aantal mensen die ik graag persoonlijk wil noemen.

De leden van de beoordelingscommissie: prof. dr. B.W.W. Kramer, prof. dr. C.E. Blanco, prof. dr. L.W. van Rhijn, prof. dr. C.E.M. de Die-Smulders en dr. H.L. Claahsenvan der Grinten wil ik graag bedanken voor het lezen en beoordelen van dit proefschrift.

Prof. dr. L.J.I. Zimmerman, mijn promotor, bedankt voor het bieden van de mogelijkheid mijn promotieonderzoek uit te voeren binnen uw vakgroep; ik heb het als bijzonder prettig ervaren.

Dr. W.J.M. Gerver, Willem-Jan, waar moet ik beginnen? "Jongen, je dankwoord hoef je niet te schrijven, dat heb ik al voor je gedaan". Ik heb het bij deze toch maar zelf geschreven, maar je hebt zeker veel voor mij gedaan. Allereerst dank ik je voor het vertrouwen en het zien van het potentieel in een $2^{\mathrm{e}}$ jaar geneeskunde student die bij je kwam met tijd over en zin om onderzoek te doen. Vier jaar later kijk ik terug op een bijzonder waardevolle periode, waarin ik, dankzij jou, zowel als mens en als onderzoeker enorm ben gegroeid. Ik ben dankbaar dat ik keer op keer de vrijheid heb gekregen om zelf ideeën uit te zoeken en het onderzoek in al zijn facetten uit te voeren. Deze vrijheid werd altijd vergezeld met waardevol advies, wat, als het nodig was, 24/7 gevraagd of ongevraagd gegeven werd. Ik had mij geen betere mentor kunnen wensen. Ik hoop dat we in de toekomst ook samen kunnen blijven werken om de fotometrie verder op de kaart te zetten. Ik blijf er enorm veel plezier en voldoening uit halen.

Dr. A.C.E. Vreugdenhil, Anita, ik ben heel blij dat jij als copromotor binnen mijn promotietraject bent aangesloten. Ondanks je overvolle agenda werd er altijd wel een gaatje gevonden om met mij over het onderzoek te sparren. Bedankt voor je steun en waardevolle feedback, ik heb er veel van geleerd en kijk uit naar verdere samenwerking in de toekomst.

Mw. Gerver, Angèle, bedankt voor al je inzet in het mee helpen verzamelen van meetgegevens, het contact met patiënten en het coördineren van de deuterium dilutie.

Dr. Brecheisen, Ralph, zonder jou was de fotometrie niet van de grond gekomen. Bedankt voor al je inzet in de ontwikkeling van het prachtige meetprogramma en technische invalshoek bij het bedenken van de fotografische techniek. 
Engelbert Schins en Ed Smeets van de medische fotografie, MUMC+, dank voor het geduld en gedeeld doorzettingsvermogen in het uitgebreid testen van onze ideeën bij de ontwikkeling van de fotometrie. Tevens dank voor jullie blijvende inzet in het fotograferen van al die patiënten waar we jullie graag voor bellen of ze bij jullie in de studio langs sturen.

Alle co-auteurs, dank voor het delen van het enthousiasme voor de fotometrie en jullie bijdrage aan de publicaties.

Dr. Busari, ik dank u voor de mogelijkheid de eindstage van mijn geneeskunde master parttime bij u uit te hebben kunnen voeren. Dit heeft mij enorm geholpen de eindspurt in te zetten voor dit proefschrift. Ik hoop dat dit resultaat het gestelde vertrouwen bekrachtigd. Ik ben enorm blij dat ik binnen uw vakgroep als artsassistent kindergeneeskunde aan de slag ben kunnen gaan.

Joop, kerel, bedankt voor het altijd hebben van een luisterend oor tijdens de goede, maar ook zware momenten. Bedankt voor de momenten van ontspanning, thuis op de bank met een glas wijn en samen op vakantie in Luxemburg, Tallinn en Helsinki. Laten we die trend vooral doorzetten in jouw promotieonderzoek, dan komt het helemaal goed.

Renée, Marit, Lex, Linda, Isanne, Yoram, Laura en Wim, ik wil jullie ook allemaal danken voor de leuke momenten samen, de ontspanning was een goede afwisseling voor de drukke combinatie van coschappen en promotieonderzoek.

Jelle, mijn lieve tweelingbroer en de ingenieur van de familie. Hoewel je in je eigen studie en promotietraject de hele wereld over reist, had je altijd tijd voor mij om mee te denken en kon je als de beste kritisch mijn stukken doorlezen, waarvoor grote dank. Ik kijk met bewondering naar de diversiteit van jouw inspanningen zowel in de academische wereld alsook die van de patisserie. Als kers op de taart bleek je ook nog eens talent voor grafische vormgeving te hebben, met als resultaat de prachtige omslag van dit proefschrift!

Pap en mam, ik kan jullie in de woorden van dit proefschrift niet genoeg bedanken. Dankzij jullie ben ik wie ik ben. Jullie hebben me altijd onvoorwaardelijk gesteund en stonden altijd klaar om mij te helpen. Bedankt!

Lieve oma Marieke, vanaf het begin van de geneeskunde opleiding was ik voor u al "Ut dökterke vaan de femilie". Ik dank u voor altijd voor ons te "beie" en voor de "teskes koffie en lekker tas sop" in het weekend.

Els en Bert, mijn lieve schoonouders. Aangezien Eline en ik al in de tweede week van de geneeskunde opleiding elkaar gevonden hadden, ben ik bevoorrecht jullie al bijna 7 jaar te kennen. Bedankt voor jullie steun en interesse in mijn promotieonderzoek. Allerliefste Eline, jij bent alles voor me. Zonder jou had ik dit nooit kunnen bereiken. Jouw doorzettingsvermogen en nuchterheid hebben mij mede geholpen. Ik kan niet wachten totdat we op 22 september 2018 gaan trouwen! 




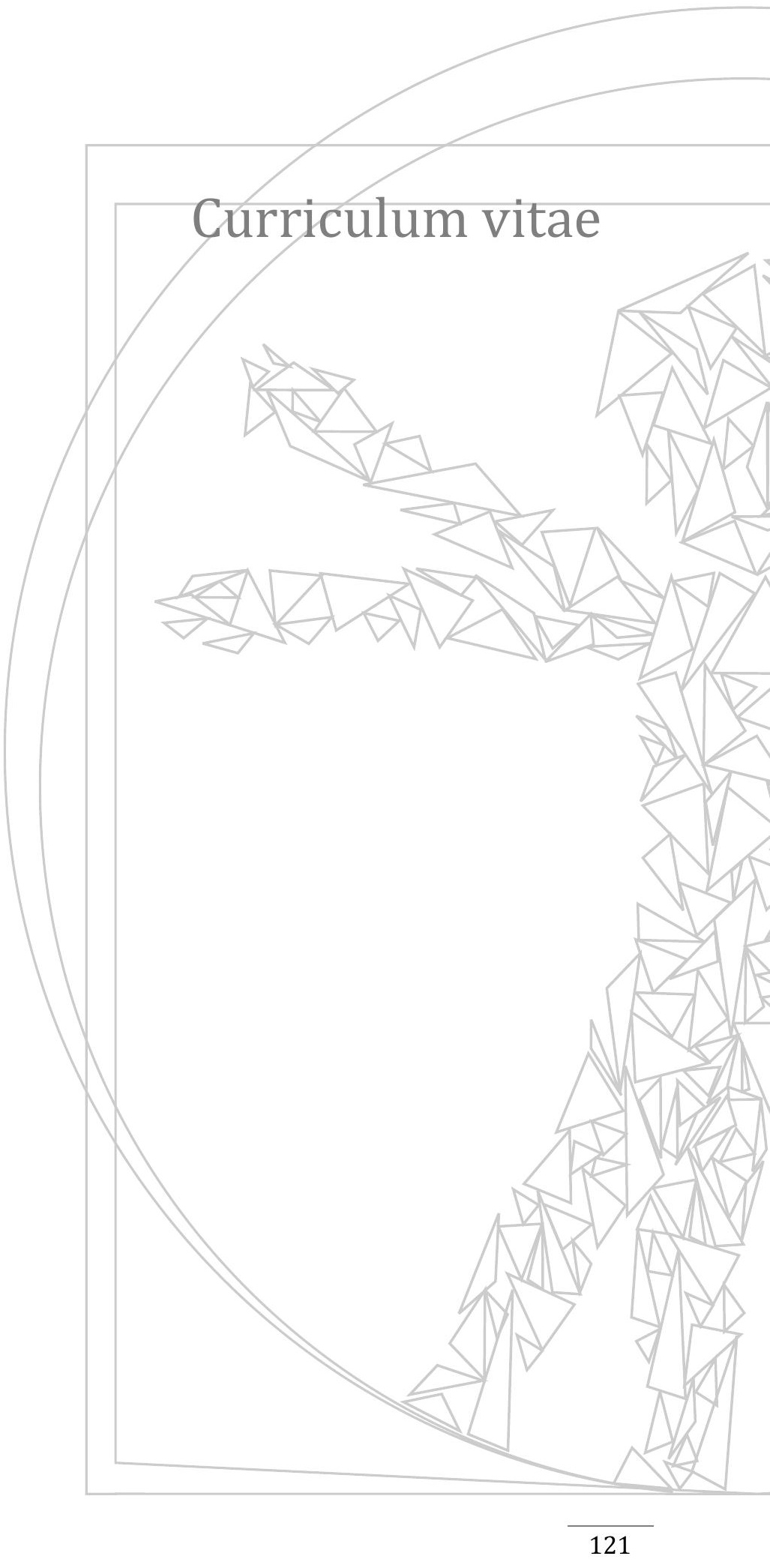





\section{Curriculum vitae}

Bas Penders was born on the 13th of December 1992 in Maastricht, the Netherlands. He graduated secondary school at Stella Maris College in Meerssen in 2011. In 2011 he started studying Medicine at Maastricht University. His $\mathrm{PhD}$ studies commenced under supervision of $\mathrm{dr}$. W.J.M. Gerver after obtaining his bachelor's degree cum laude. He continued this research throughout his master's studies. His research

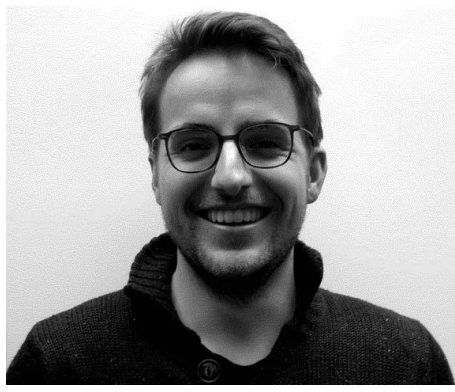
focuses on the development of the photogrammetric anthropometry technique and body proportions in children. He presented his work at two international congresses. The most important scientific results are described in this thesis. After graduating cum laude in February 2018, he started working as a medical doctor at the Department of Paediatrics, Zuyderland Medical Centre in Heerlen under supervision of dr. Jamiu Busari. He lives in Maastricht together with Eline, who he will be married to on 22 september 2018 . 



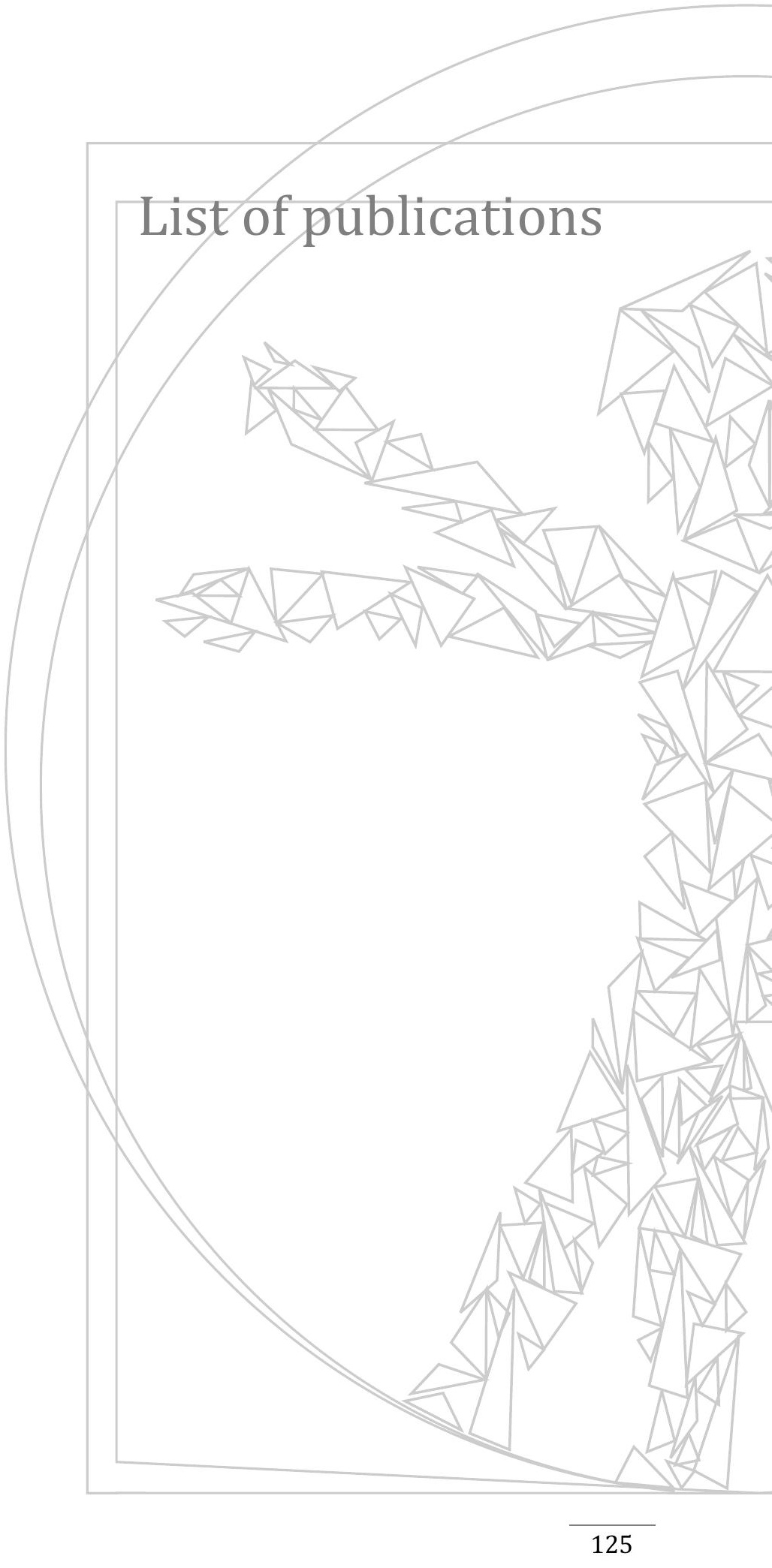





\section{List of publications}

2018 Penders B, Vreugdenhil ACE, Rijks JM, Gerver WJM. Estimation of body fat percentage in children and adolescents using photogrammetric anthropometry (submitted)

2018 Penders B, Dijk DR, Bocca G, Zimmermann LJI, van Ravenswaaij-Arts CMA, Gerver WJM. An analysis of body proportions in children with CHARGE syndrome using photogrammetric anthropometry. (submitted)

2017 Rijks JM, Plat J, Dorenbos E, Penders B, Gerver WJM, Vreugdenhil ACE. Association of TSH with cardiovascular disease risk in overweight and obese children during lifestyle intervention. The Journal of Clinical Endocrinology and Metabolism. JCEM. 2017 Jun 1;102(6):2051-2058

2016 Rijks JM, Penders B, Dorenbos E, Straetemans S, Gerver WJM, Vreugdenhil ACE. Pituitary response to thyrotropin releasing hormone in children with overweight and obesity. Scientific Reports. 2016 Aug; 3;6:31032

2016 Penders B, Schott N, Gerver WJM, Stumpel CT. Body proportions in children with Kabuki syndrome. American Journal of Medical Genetics part A: AJMG. 2016 Mar; 170(3):610-4

2015 Penders B, Brecheisen R, Gerver A, van Zonneveld G, Gerver WJM. Validating Paediatric Morphometrics: body proportion measurement using photogrammetric anthropometry. Journal of pediatric endocrinology \& metabolism. JPEM. 2015 Nov 1;28(11-12):1357-62

2015 Gerver WJM, Penders B, Brecheisen R. Chapter: Body Proportions. Elsevier. Online Reference Module in Biomedical Sciences. 2015 


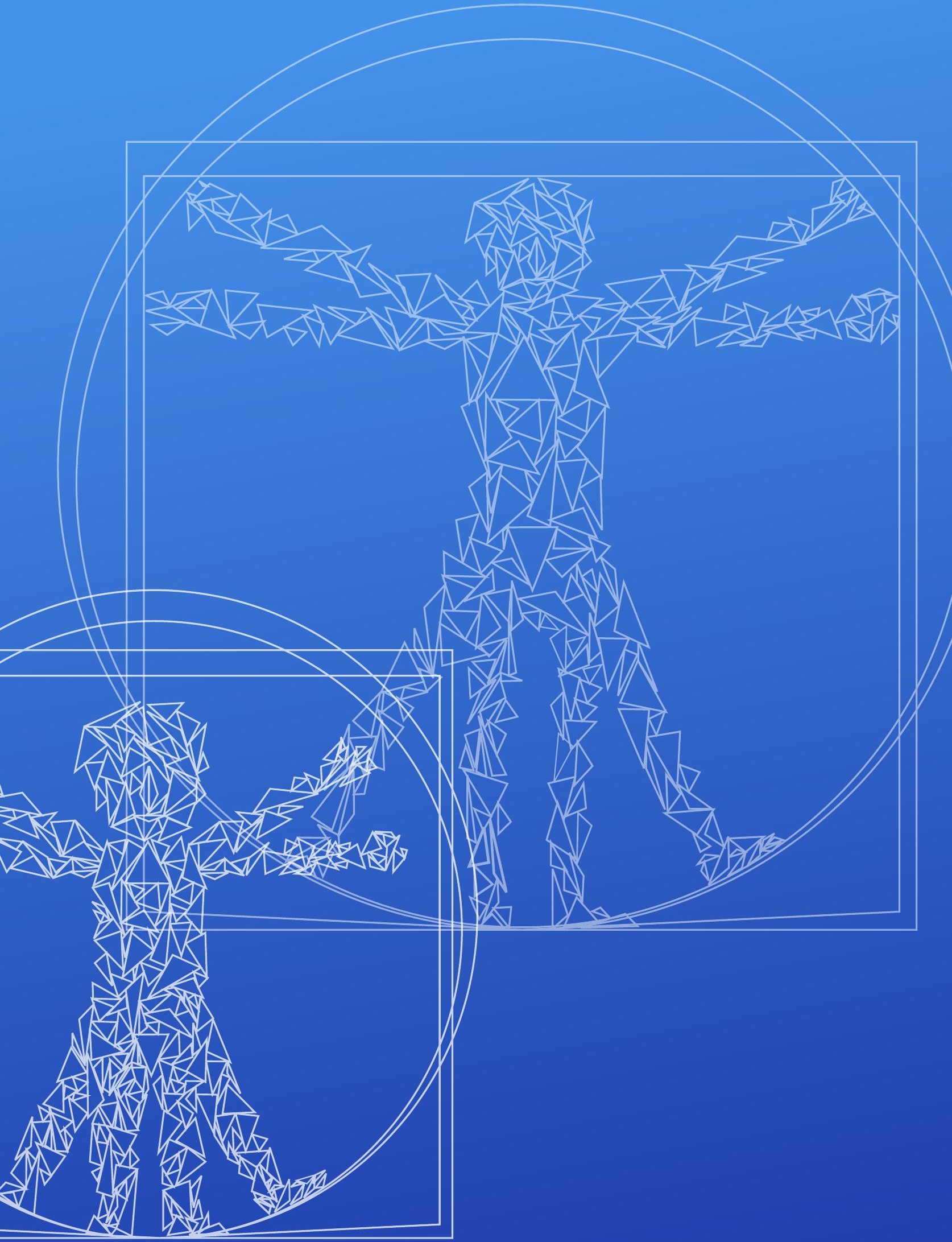

